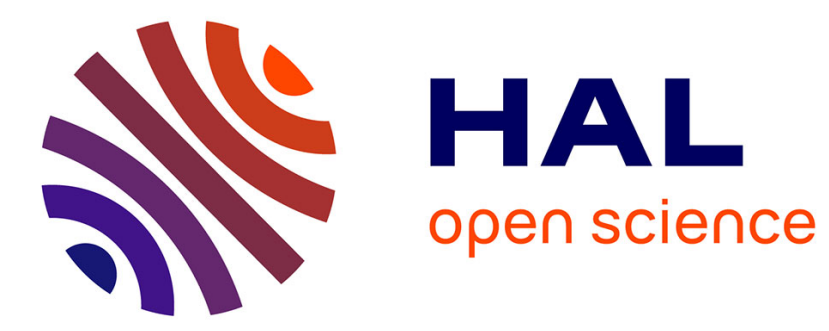

\title{
P-T-time-isotopic evolution of coesite-bearing eclogites: Implications for exhumation processes in SW Tianshan
}

\author{
Zhou Tan, Philippe Agard, Jun Gao, Timm John, Jilei Li, Tuo Jiang, Léa
} Bayet, Xinshui Wang, Xi Zhang

\section{- To cite this version:}

Zhou Tan, Philippe Agard, Jun Gao, Timm John, Jilei Li, et al.. P-T-time-isotopic evolution of coesite-bearing eclogites: Implications for exhumation processes in SW Tianshan. Lithos, 2017, 278281, pp.1-25. 10.1016/j.lithos.2017.01.010 . hal-01471612

\section{HAL Id: hal-01471612 \\ https://hal.science/hal-01471612}

Submitted on 1 Mar 2017

HAL is a multi-disciplinary open access archive for the deposit and dissemination of scientific research documents, whether they are published or not. The documents may come from teaching and research institutions in France or abroad, or from public or private research centers.
L'archive ouverte pluridisciplinaire HAL, est destinée au dépôt et à la diffusion de documents scientifiques de niveau recherche, publiés ou non, émanant des établissements d'enseignement et de recherche français ou étrangers, des laboratoires publics ou privés. 


\section{P-T-time-isotopic evolution of coesite-bearing eclogites: implications for exhumation processes in SW Tianshan}

Key words: UHP metamorphism; eclogite; P-T path; pseudosection modeling; thermobarometry; zircon U-Pb; zircon oxygen isotope; exhumation pattern; Chinese Southwestern Tianshan;

\section{Authors:}

Zhou Tan ${ }^{a, b, c}$, Philippe Agard ${ }^{b, d}$, Jun Gao ${ }^{a, c,{ }^{*},}$ Timm John $^{e}$, JiLei Li ${ }^{a}$, Tuo Jiang ${ }^{f}$, Léa Bayet ${ }^{e}$, XinShui Wang ${ }^{a, c}$, Xi Zhang ${ }^{g}$

a. Key Laboratory of Mineral Resources, Institute of Geology and Geophysics, Chinese Academy of Sciences, 100029 Beijing, China

b. Sorbonne Universités, UPMC Univ Paris 06, CNRS, Institut des Sciences de la Terre de Paris (ISTeP), 4 place Jussieu, 75005 Paris, France

c. University of Chinese Academy of Sciences, 100049 Beijing, China

d. Insitut Universitaire de France, F-75005, Paris, France

e. Institut für Geologische Wissenschaften, Freie Universität Berlin, Malteserstr. 74-100, D-12449, Berlin, Germany

f. Laboratory of Isotope Geochemistry, Wuhan Centre of China Geological Survey, 430205 Wuhan, China

g. China Minmetals Corporation, 100010 Beijing, China

*corresponding author: Jun Gao,gaojun@mail.iggcas.ac.cn 


\section{Abstract}

The Chinese Southwestern Tianshan high- to ultra-high pressure low temperature (HP-UHP/LT) metamorphic belt exhibits well-preserved mafic layers, tectonic blocks/slices and boudins of different sizes and lithology embedded within dominant meta-volcanosedimentary rocks. Despite a wealth of previous studies on UHP relicts, P-T paths estimates and age constraints for metamorphism, controversies still exist on P-T-t assessments and regional exhumation patterns (i.e., tectonic mélange versus internally coherent "sub-belt" model). This study focuses on a group of coesite-bearing eclogite samples from a thick ( $\sim 5$ meters) layered metabasalt outcrop in order to unravel its detailed tectono-metamorphic evolution through space and time (both prograde, peak and exhumation). Using SIMS zircon U-Pb and oxygen isotope analyses, TIMS Sm-Nd multi-point isochron dating, in situ laser-ICP-MS trace-element analyses, classical thermobarometry and thermodynamic modeling, we link the multistage zircon growth to garnet growth and reconstruct a detailed P-T-time-isotopic evolution history for this UHP tectonic slice: from UHP peak burial $~ 2.95 \pm 0.2 \mathrm{GPa}$, $510 \pm 20^{\circ} \mathrm{C}$ around $318.0 \pm 2.3 \mathrm{Ma}$ to HP peak metamorphism 2.45 $\pm 0.2 \mathrm{GPa}, 540 \pm$ $20{ }^{\circ} \mathrm{C}$ at $316.8 \pm 0.8 \mathrm{Ma}$, then, with eclogite-facies deformation $\sim 2.0 \pm 0.15 \mathrm{GPa}, 525 \pm$ $25{ }^{\circ} \mathrm{C}$ at $312 \pm 2.5 \mathrm{Ma}$, exhumed to near surface within ca. 303 to ca. $280 \mathrm{Ma}$. Our P-T-time-isotopic results combined to the compilation of regional radiometric data and P-T estimates notably point to the existence of a short-lived period of rock detachment and exhumation (<10 Ma, i.e. at ca. $315 \pm 5 \mathrm{Ma}$ ) with respect to subduction duration. 


\section{Introduction}

Mechanisms and processes responsible for the occasional recovery of negatively buoyant, ocean-derived high- to ultra-high pressure low temperature (HP-UHP/LT) eclogites equilibrated along the subduction plate interface and for their juxtaposition as tectonic slices or blocks during exhumation remain a matter of debate (Agard et al., 2009; Burov et al., 2014; Chen et al., 2013; Federico et al., 2005; Gerya et al., 2002; Guillot et al., 2009; Klemd et al., 2011; Lü et al., 2012; Warren, 2013; Warren et al., 2008). The Southwestern Tianshan Akeyazi HP-UHP/LT metamorphic belt potentially provides an interesting test example, with well-preserved mafic horizons or tectonic blocks/slices/boudins of different sizes (from the $\mathrm{cm}$ - to $\mathrm{km}$-scale) embedded in volumetrically dominant meta-volcanosedimentary rocks (Gao and Klemd, 2003; Gao et al., 1999; Meyer et al., 2016).

However, despite numerous previous works (on UHP relicts, detailed petrology, P-T estimates on isolated blocks/slices and time constraints on the timing of metamorphism; section 2), the area is still a matter of controversy as to (i) the exact P-T evolution and age of metamorphism, (ii) whether the metamorphic belt may be composed of two distinct HP and UHP slices and (iii) 
whether mafic bodies represent a tectonic mélange (Du et al., 2014; Gao et al., 1999; Klemd et al., 2011; Li et al., 2015; Meyer et al., 2016) or an assembly of km-scale tectonic slices (Lü et al., 2012).

Uncertainties partly arise from the fact that conclusions were drawn on spectacular but isolated samples (sometimes from loose scree and river beds) rather than on an extensive coverage of the area, and do not tightly enough link recrystallization observations with P-T data. In order to contribute to clarifying these issues, we herein review and reappraise available P-T-t constraints for the area (Figs. 1b, 2) and perform a combined P-T-radiometric-isotopic study on several eclogitic samples from a key location. Samples come from a thick ( $5 \mathrm{~m}$ ) layered eclogite outcrop close to where UHP was previously reported (Lü and Zhang, 2012, Fig. 1b) and were chosen to provide detailed constraints on their tectono-metamorphic and geochronological evolution (prograde, peak and exhumation stages) using SIMS high precision $\mathrm{U}-\mathrm{Pb}$ isochron dating of zircon grains and whole-rock the TIMS Sm-Nd technique. Implications for recrystallization and exhumation processes are discussed and set back within the frame of the regional geodynamic evolution. 


\section{Geological setting}

\subsection{The Chinese Southwestern Tianshan HP-UHP/LT metamprphic complex}

The Chinese Southwestern Tianshan high- to ultrahigh-pressure low-temperature metamorphic complex extends for about $200 \mathrm{~km}$ along the Southwestern Central Tianshan Suture Zone (SCTSZ; Fig. 1). It is correlated with the Atbashi metamorphic complex in the Southwestern Tianshan Accretionary Complex (Hegner et al., 2010) and the Fan-Karategin metamorphic belt (Volkova and Budanov, 1999). Gao et al. (1998) proposed that this HP-UHP/LT complex formed from the northward subduction of the South Tianshan ocean and subsequent collision between the already amalgamated Kazakhstan-Yili-Central Tianshan terrane, in the north, and the Tarim-Karakum plates in the south. Subduction polarity is still debated, however, with alternative suggestions of southward subduction (e.g.Lin et al., 2008).

The Southwestern Central Tianshan Suture Zone bounds to the north the Chinese section of the HP-UHP/LT metamorphic complex, known as the Akeyazi metamorphic complex. This contact, now a $\sim 0.5 \mathrm{~km}$ wide sinistral strike-slip shear zone, was active from the late Permian to early Triassic (Gao et al., 1995; Gao and Klemd, 2000, 2003). To the north lies a LP-HT Palaeozoic active continental margin (Allen et al., 1993; Gao et al., 1998; Klemd et al., 
2014), mainly made of amphibolite- and granulite-facies rocks, along with Late Silurian and Early Carboniferous continental arc-type volcanic and volcaniclastic rocks and granitoids (Gao and Klemd, 2003; Gao et al., 2009; Xia et al., 2014). The Akeyazi metamorphic complex (AMC) is overlain to the southwest by unmetamorphosed Palaeozoic sedimentary strata representing the northern, passive continental margin on margin of the Tarim plate (Allen et al., 1993; Carroll et al., 1995).

The Akeyazi metamorphic complex is predominantly composed of strongly schistosed meta-volcanosedimentary rocks hosting mafic metavolcanics, marbles and rare ultramafic rocks. Mafic metavolcanics are eclogites and/or blueschists showing gradual transitions or interlayering (Li et al., 2012). They are distributed as pods, boudins, thin layers or massive blocks in the host rocks (Gao and Klemd, 2003). The AMC was interpreted by some as a tectonic mélange and thought to have formed in a subduction accretionary wedge during subduction of the Southwestern Tianshan ocean (Gao and Klemd, 2003; Gao et al., 1999). Both the metavolcanics and the matrix meta-volcanosedimentary were variably retrogressed under blueschist and/or greenschist facies conditions.

Whole-rock geochemical data for the mafic metavolcanics suggest ocean basalt or arc-related affinities (Gao and Klemd, 2003; John et al., 2008; Klemd et al., 2005). A recent study indicated that some eclogite boundins also have a 
continental arc affinity protolith, possibly originating from the basement of a Palaeozoic continental arc setting (Liu et al., 2014a).

\subsection{Previous age constraints on the P-T evolution of tectonic}

\section{slices/blocks}

Most peak metamorphic estimates for eclogites and prograde blueschists (differences are largely controlled by lithology) yield eclogite-facies HP-LT conditions within the range $480-580^{\circ} \mathrm{C}$ and 1.5-3.0 GPa (Beinlich et al., 2010; Gao et al., 1999; John et al., 2008; Klemd et al., 2002; Li et al., 2016; Meyer et al., 2016; Soldner et al., 2016; Wei et al., 2003). A range of P-T conditions of 570-630 ${ }^{\circ} \mathrm{C}$ at 2.7-3.3 GPa was obtained for eclogite-facies micaschists (Wei et al., 2009; Xin et al., 2013), and $470-510^{\circ} \mathrm{C}$ at 2.4-2.7 GPa for eclogites (e.g. Meyer et al., 2016, see Table. S2 for references). Evidence for UHP metamorphism comes from both relict coesite inclusions in garnet in several localities (stars in Fig. 1b) and thermodynamic pseudosection modeling (Lü et al., 2008, 2009; Lü et al., 2012; Tian and Wei, 2013; Wei et al., 2009). The spread of P-T estimates (Du et al., 2011; Gao et al., 1995; Gao et al., 1999; Klemd et al., 2002; Li et al., 2015; Li et al., 2016; Li et al., 2012; Lü et al., 2009; Lü et al., 2012; Tian and Wei, 2013; Wei et al., 2003) may a priori arise from contrasting assumptions for thermodynamic modeling (and/or difficulties in determining $\mathrm{Fe}^{3+}$ content and assessing $\mathrm{H}_{2} \mathrm{O}$ activity) or from the complexity of 
metamorphic evolutions in individual HP-UHP tectonic slices.

The exhaustive compilation of age data (location on Fig. 1b), and the comparison of previous age data versus their assessed $\mathrm{P}_{\max }$ estimates (figures $2 \mathrm{a}$ and $2 \mathrm{~b}$ ), evidence a considerable spread in ages too, with an overlap between eclogite and blueschist ages, whatever the protolith (Fig. 2a). The timing of peak metamorphic conditions falls in the range 325-305 Ma. Garnet growth by multi-point Lu-Hf isochron was dated at ca. $315 \mathrm{Ma}$ (Klemd et al., 2011), for both eclogites and blueschists from a variety of valleys within AMC. $\mathrm{U}-\mathrm{Pb} \mathrm{SIMS}$ ages from metamorphic zircon rims in eclogites are indistinguishable within error, at $319 \pm 3$ Ma and $321 \pm 2$ Ma (Liu et al., 2014a; Su et al., 2010) and similar to a U-Pb age of $318 \pm 7$ Ma obtained for eclogite-facies rutile (Li et al., 2011). Du et al. (2014) also reported a suite of relative consistent $\mathrm{Sm}-\mathrm{Nd}$ isochron ages of $309 \pm 4.6 \mathrm{M}, 306 \pm 15 \mathrm{Ma}$ and $305 \pm$ $11 \mathrm{Ma}$ for eclogites from the Habutengsu river (Fig. 1b). An age of $317 \pm 5 \mathrm{Ma}$ was obtained on high-pressure veins crosscutting a blueschist wall-rock, interpreted as the prograde dehydration-related transformation of blueschist to eclogite (Rb-Sr multi-point isochron, John et al., 2012). Recent Sm-Nd and Lu-Hf isochron ages of $318.4 \pm 3.9 \mathrm{Ma}$ and $326.9 \pm 2.9 \mathrm{Ma}$ on blueschists (Soldner et al., 2016) were interpreted as peak eclogite-facies and prograde metamorphism, respectively. Post-peak cooling was constrained by white mica K-Ar, Ar-Ar and Rb-Sr ages at around 310 Ma (Klemd et al., 2005). Ages < 
$280 \mathrm{Ma}$ or $>$ than $\sim 325 \mathrm{Ma}$ were considered by most authors as resulting from limitations of isotopic dating (e.g. excess Ar in Ar-Ar system; Nd disequilibrium in Sm-Nd system; difficulties to relate zircon U-Pb ages to metamorphic stages) or taken as evidence for distinct HP-UHP episodes.

\subsection{Controversy on regional exhumation}

The Akeyazi metamorphic complex is either interpreted as a tectonic mélange or as made of two main units. In the first interpretation, mafic slices/blocks derived from different depths (UHP and HP conditions) were juxtaposed and mixed during exhumation in a meta-volcano-sedimentary subduction channel-like setting (Klemd et al., 2011; Li et al., 2016; Meyer et al., 2016). Despite, indications that rocks may have partly re-equilibrate with fluids in equilibrium with serpentinites (van der Straaten et al., 2008, 2012), serpentinites, which can act as buoyant material during exhumation processes (Guillot et al., 2015), are extremely rare (Shen et al., 2015). Meta-volcanosedimentary rocks could also act as buoyant material and promote the exhumation of denser, negative-buoyant oceanic HP-UHP/LT rocks in a subduction channel (Gerya et al., 2002).

In contrast, the coherent sub-belt model (Lü et al., 2012), based on several individual UHP occurrences in the northern part of the AMC and the prevalence of blueschist facies rocks without UHP "signal" in the south, considers that the 
AMC consists of two internally coherent metamorphic "sub-belts": a UHP in the north and a HP belt in the south, separated by a major fault contact (only inferred at present) and later juxtaposed during exhumation.

\section{Sample selection and whole-rock composition}

Samples were collected from the second eastern tributary up the Atantayi valley (Fig. 1b) in a six meter thick, layered eclogitic mafic slice. In order to detailedly reconstruct its tectono-metamorphic evolution (pro- and retrograde), three fresh eclogite samples were chosen from the core of the thick-layered eclogite outcrop (Fig. 3; oriented samples: GJ01-6, 11AT06-2; for geochemistry: 11AT06-1) and one garnet-clinopyroxene-quartz bearing micaschist from the meta-volcanosedimentary host-rock (GJ01-1). Considering the relative low $\mathrm{Zr}$ content (only ca. $50 \mathrm{ug} / \mathrm{g}$ ) of the metabasalts (Table. 2), about 100 kilograms of eclogite were sampled for the zircon study and approximately 500 zircon grains were collected and mounted (detailed processing is given in the Analytical methods in the Appendix).

Bulk- and trace-element geochemical data are shown in table. 2 and figure.

4. Loss on ignite on ranges between 1.8 and $3.3 \mathrm{wt}$ \%, in agreement with modal abundances of hydrous mineral such as amphibole (5 to 8 vol\%).

Chondrite- and primitive mantle-normalized (Sun and McDonough, 1989) rare earth element (REE) and trace-element patterns of the eclogites are 
similar to N-MORB (Figs. 4a, b), as further supported by a Th/Yb vs. Nb/Yb plot (Fig. 4c) and by the $\varepsilon N d(t)$ value of $+8.5(t=c a .312 \mathrm{Ma}$, Table. 7$)$. They show a positive slope in LREEs to MREEs and flat in HREEs, with $(\mathrm{La} / \mathrm{Yb})_{\mathrm{N}}=0.542-$ 1.097, $(\mathrm{La} / \mathrm{Sm})_{\mathrm{N}}=0.524-0.666,(\mathrm{Gd} / \mathrm{Yb})_{N}=0.999-1.536$ and a $\Sigma \mathrm{REE}$ concentration of 49.9 to 58.2 ppm (Table. 2). Primitive mantle-normalized trace-element variations show moderate $\mathrm{Rb}, \mathrm{Ba}, \mathrm{U}$ and $\mathrm{Pb}$ enrichments (Fig. 4b) for these three eclogite samples. As expected for MORB type samples, there is no $\mathrm{Nb}$-Ta depletion recorded.

The meta-volcanosedimentary rock is characterized by relatively high $\mathrm{SiO}_{2}$ ( 54.3 wt.\%) and $\mathrm{Al}_{2} \mathrm{O}_{3}(\sim 14.7$ wt.\%) contents. LREEs are enriched with $\mathrm{La}$ contents $\sim 100$ times higher than for chondrite, while HREE patterns are flat. REE and trace-element patterns for this meta-volcanosedimentary sample are close to that of the average upper continental crust (Fig. 4b, Rudnick and Gao, 2003) except for $\mathrm{Rb}$.

\section{Petrology}

Mineral occurrences and modal abundances are given in Table. 1. Mafic samples are true eclogites with $>70$ vol. \% of garnet and omphacite (Carswell, 1990). Mineral constituents of eclogite samples are garnet, omphacite, epodite-group minerals, paragonite, blue amphibole (rimmed in places by 
blue-green amphibole), quartz, as well as rutile/titanite, calcite and phengite (Figs. 5a-f) in subordinate amounts. The fraction of hydrous minerals (especially amphibole) increases in the vicinity of the host-rock.

Garnet in sample 11 AT06 occurs as idioblastic porphyroblasts ( $\sim 0.4$ to 2.5 $\mathrm{mm}$ in diameter; Figs. 5d, 5e) in a medium-grained omphacite matrix. The inclusion-rich cores (Fig. 5e) host omphacite, epidote, chlorite, paragonite, quartz and glaucophane/barroisite (Fig. S2). Box-shaped inclusions of aggregates of paragonite and epidote could represent pseudomorphs after lawsonite (Fig. S2). Coesite inclusions (Figs. 7b,c) were found in the garnet mantle (Fig. 7d), where inclusions are much less than in the core.

Omphacite occurs as small subhedral-anhedral grains $(\sim 0.05$ to $0.1 \mathrm{~mm}$ across), either as the main matrix phase or as inclusions in garnet, epidote and paragonite (Figs. 5b, 5d, 5f, 5i). Epidote is subhedral and contains inclusions of omphacite, quartz and rutile (Fig. 5d). Blue amphibole is found as inclusions in some garnets (Fig. 5h) and in the core of late-stage blue-green amphibole (Fig. $5 \mathrm{~g}$ ). Rutile is present both in garnet porphyroblasts (Fig. 5e), paragonite and amphibole grains as armored relicts, and in the matrix (Fig. $5 \mathrm{~g}$ ), where it is replaced by helicitic rims of titanite (Fig. S1). Retrograde albite is rare and xenoblastic. Chlorite replaces or cuts across garnet (Fig. 5e).

In oriented eclogite samples (11AT06-2 and GJ01-6), omphacite defines a weak to moderate foliation, and contain aggregates of epidote group minerals 
and paragonite aligned along the matrix foliation (Figs. 5f, 6a, 6b). In the XZ plane of deformation, $\sigma$-type garnet porphyroclasts with recrystallized aggregate tails made of epidote, omphacite and paragonite/phengite indicate top to NE shear senses.

The meta-volcanosedimentary sample GJ01-1 is strongly deformed and the foliation defined by lepidoblastic phengite/paragonite, albite and amphibole wraps around garnet porphyroclasts (Fig. 6c). Garnet occurs as idioblastic to subidioblastic $\sim 3.0 \mathrm{~mm}$ sized porphyroblasts in a fine- to medium-grained matrix, and contains inclusions of phengite/paragonite, epidote group minerals, quartz and chlorite. Matrix feldspar porphyroblasts contain numerous inclusions. Shear sense indicators, again top to the NE, correspond to retrograde greenschist/blueschist facies recrystallization.

\section{Mineral chemistry}

A selection of representative EPMA analyses is provided in Table. 3. Mineral abbreviations are after Whitney and Evans (2010).

\subsection{Garnet}

Garnet porphyroblasts in eclogite sample 11AT06-1 exhibit systematic compositional zoning (e.g., Fig. 7e) with a core-mantle increase in pyrope $\left(X_{\text {prp }}\right)$ 
and a slight decrease in spessartine and grossular content $\left(\mathrm{X}_{\mathrm{sps}}\right.$ and $\left.\mathrm{X}_{\mathrm{grs}}\right)$. The almandine $\left(\mathrm{X}_{\mathrm{alm}}\right)$ profile is fairly constant from core to mantle then decreases steadily towards the outermost part of the rim (Fig. 7e). Second-order fluctuations in $X_{\text {grs }}$ and $X_{\text {sps }}$ but also in $X_{\text {alm }}$ can be observed (Fig. 7e). Garnet profiles may show a rim-outer rim coeval increase in $\mathrm{X}_{\mathrm{alm}}$ and decrease in $\mathrm{X}_{\text {prp, }}$, which is generally attributed to retrograde reequilibration by diffusion (Wei et al., 2009).

Garnet zoning in eclogite is highlighted by seven spots along the EMPA profile (Fig. 7e), which are used in pseudosection modeling (section 8.2). Overall, garnet composition changes from core to mantle and rim from $\mathrm{Alm}_{67} \mathrm{Py}_{10} \mathrm{Grs}_{20} \mathrm{Sps}_{4}$ to $\mathrm{Alm}_{70} \mathrm{Py}_{12} \mathrm{Grs}_{18} \mathrm{Sps}_{1}$ to $\mathrm{Alm}_{57} \mathrm{Py}_{21} \mathrm{Grs}_{22} \mathrm{Sps}_{0.3}$ (Table. 3). These average values correspond to the Grt-C, Grt-M1 to M2 and Grt-M5 to R zones defined in Fig. $7 d$, and to the approximate location of the LA-ICPMS trace element analyses of the garnet core, mantle and rim.

\subsection{Omphacite}

Clinopyroxene is always omphacitic, but inclusions in garnet and matrix clinopyroxene show distinct compositional variations (Fig. 7f). Inclusions have a lower jadeite content (31-45 mol.\%, average $38 \mathrm{~mol} . \%)$ and a higher total FeO content (4.3-12.9 wt.\%, average 7.7 wt.\%) than matrix omphacite (40-51 mol.\% Jd and 2.5-6.5 wt.\% FeO, respectively). Both have similar values of 
$\mathrm{Na}_{N} /\left(\mathrm{Na}_{N}+\mathrm{Ca} \mathrm{a}_{N}\right)(\sim 0.48$; Table. 3). Omphacite inclusions in paragonite lie on the upper bound for jadeite content and $\mathrm{Na} /\left(\mathrm{Na}_{N}+\mathrm{Ca}\right)$ but on the lower bound for the total FeO content.

\subsection{Amphibole}

Amphibole in the layered eclogite is either glaucophane or barroisite (Fig. $7 \mathrm{~g})$. Glaucophane occurs as euhedral porphyroblasts ( 0.5 $\mathrm{mm}$ across) with barroisite rims (Fig. $5 \mathrm{~g}$ ). Both glaucophane and barroisite appear as inclusions in garnet, with a wide range of compositions for the latter, across the magnesio-katophorite field (Leake, 1978) and a systematic decrease in ( $\mathrm{Na})_{\mathrm{M} 4}$

(Fig. 5h). Glaucophane inclusions have higher $\mathrm{Fe}^{2+} /\left(\mathrm{Fe}^{2+}+\mathrm{Mg}\right)$ and $\mathrm{Fe}^{3+} /\left(\mathrm{Fe}^{3+}+\mathrm{Al}\right)$ ratios. Some amphibole grains have a clear zonation, with glaucophane in the core and barroisite in the rim, similar to the Tianshan garnet-omphacite blueschist samples described by Klemd et al. (2002).

\subsection{White mica}

Paragonite and minor phengite appear as matrix mineral and as inclusions in garnet. Paragonite flakes occur as subhedral fine grains ( 0.05 mm across) or occasionally as porphyroblasts in the matrix ( $\sim .5$ to $2 \mathrm{~mm}$ across, Figs. $5 \mathrm{f}$, $5 g, 5 i$ ). They are parallel or subparallel to the foliation (Figs. $5 f, 5 g$ ), contain omphacite and rutile inclusions (Figs. $5 \mathrm{~g}, 5 \mathrm{i}$ ), and are interpreted to result from post-peak retrograde metamorphism. Phengite mainly occurs as subhedral fine 
grains in the matrix ( $\sim 0.02 \mathrm{~mm}$ across) or as inclusions in garnet porphyroblasts (Fig. S2). Both of them exhibit a similar Si content ( 3.43 p.f.u.).

\subsection{Epidote-group minerals}

Epidote-group minerals occur as $0.5-0.7 \mathrm{~mm}$ large porphyroblasts or as subhedral grains close to garnet porphyroblasts (Figs. 5c, 5d, 5e). Porphyroblasts are randomly oriented in the matrix with mineral inclusions of omphacite and rutile (Fig. 5c). The pistacite $\left(=\mathrm{Fe}^{3+} /\left(\mathrm{Fe}^{3+}+\mathrm{Al}\right)\right)$ contents of epidote range from 0.09 to 0.17 (Table. 3 ).

\subsection{Chlorite}

Chlorite appears as matrix minerals filled into the fractures of garnet porphyroblasts or as inclusions in garnet (Table. 3).

\subsection{Rutile/Titanite}

Rutile appears as acicular or irregular crystals inclusions in paragonite (Fig. 5g), glaucophane/barroisite (Fig. 5g), garnet (Fig. S2) and matrix minerals (Fig. S1). A titanite-armor around rutile is observed in both matrix omphacite (Figs. S1a, S1b) and quartz (Figs. S1c, S1d). The $\mathrm{TiO}_{2}$ and $\mathrm{Al}_{2} \mathrm{O}_{3}$ contents of titanite are respectively about 37.9 wt \% and 2.11 wt \% (Table. 3). 


\section{Trace-element pattern of zircon and garnet}

Zircon in layered eclogite occurs as 30 to 50 um grains in the matrix (Fig. $7 a$ ) or in garnet (Figs. 7a, S2). Cathodoluminescence images of zircon grains are used below as a proxy for variations in zircon chemistry (whereas trace-element patterns are discussed in next section). Zircon grains from eclogitic samples show two to four growth zones preserved (Figs. 8, S2a-I). A dull-luminescent core domain is found in all zircon grains (Figs. 8, S2a-I), with typical sector zoning. A large overgrowth is generally present and herein referred to as the 'mantle'. Complex zoning patterns (chaotic and wavy zoning) were also observed (Figs. 8a, 8e and S2). A light-luminescent outer rim can also be distinguished in many grains (e.g., Fig. 8 and Fig. S3). A metamorphic origin may be attribute to these zircon domains when considering the $<0.01$ $\mathrm{Th} / \mathrm{U}$ ratios and the presence of diagnostic HP minerals, such as omphacite and rtile, detected via Raman spectroscopy (with peaks at $682 \mathrm{~cm}^{-1}$ and 609 $\mathrm{cm}^{-1}$, respectively; Figs. S3m, S3n). Quartz was observed but never coesite.

\subsection{Trace-element pattern and oxygen isotopes of zircon}

Based on differences in cathodoluminescence (CL) images and chondrite-normalized REE patterns (and U-Pb chronology, which will be discussed in section 7.1), four zircon domains (or growth stages) have been defined from core to rim: respectively (1) the zircon core, (2) a zone enriched in 
HREE (with the same CL characteristics as the core, but more rarely preserved), (3) a mantle zone and (4) the zircon rim.

Chondrite-normalized REE patterns of zircon cores (Fig. 9a) show a typically positive slope from LREE to MREE, a relative enrichment in HREE $\left((\mathrm{Lu} / \mathrm{Sm})_{\mathrm{N}} \sim 22.94\right)$ and flat HREE patterns $\left((\mathrm{Lu} / \mathrm{Tb})_{\mathrm{N}} \sim 1.53\right)$. This core is also characterized by low $\mathrm{Th} / \mathrm{U}$ ratios $(<0.01)$, medium $\mathrm{U}(\sim 980 \mathrm{ppm})$, low Th $(\sim 4$ ppm) and moderate $\mathrm{Y}, \mathrm{Ti}, \mathrm{P}$ and $\mathrm{Nb}$ contents (with average values of 89, 2670, 27 and 6 ppm, respectively; Table. 4).

Some of the zircon cores show HREE contents 2-3 times higher $\left((\mathrm{Lu} / \mathrm{Sm})_{\mathrm{N}}\right.$ $\sim 51.72 ;(\mathrm{Lu} / \mathrm{Tb})_{\mathrm{N}} \sim 2.71 ; \mathrm{Y} \sim 230$ ppm; Figs. 9a, S3i-l; Table. 4). They are also distinct in terms of U-Pb isotopic composition (Fig. 10), but have similar Th/U ratios $(<0.01), \mathrm{U}$ and Th contents.

The zircon mantle domain (Fig. 9b) shows a more gentle positive slope from LREE to MREE and a flat HREE distribution with lower HREE and $Y$ absolute contents $\left((\mathrm{Lu} / \mathrm{Eu})_{\mathrm{N}} \sim 3.17 ;(\mathrm{Lu} / \mathrm{Tb})_{\mathrm{N}} \sim 0.94 ; \mathrm{Y}\right.$ content $\sim 45 \mathrm{ppm}$; Table. 4).

The REE pattern of zircon rims differ largely from that of the former three zones discussed above by a steeper MREE to HREE distribution (with (Lu/Gd) $\sim 10$ and $(\mathrm{Lu} / \mathrm{Tb})_{\mathrm{N}} \sim 34$, Table. 4) and the absence of a HREE plateau. Its $\mathrm{Y}, \mathrm{P}$, Th and $U$ contents are also much lower (i.e., respectively, $\sim 48,21,0.17$ and $30 \mathrm{ppm})$. The Th and $U$ contents are about 30 times less than in the other 
three zircon domains.

\subsection{Trace-element pattern of garnet}

Laser spots for the analysis of garnet core, mantle and rim corresponding to EPMA analyses of the $\mathrm{C}, \mathrm{M} 1$ to $\mathrm{M} 2$ and $\mathrm{M} 5$ to $\mathrm{R}$ areas (shown in Fig. $7 \mathrm{~d}$ ).

Chondrite-normalized REE patterns of garnet core, mantle and rim (Fig. 9b) are broadly similar (and comparable to the REE distributions within zircon), with relatively high and flat HREE content and relative depletion in MREE and LREE. Garnet cores show the highest HREE enrichment with $(\mathrm{Lu} / \mathrm{Sm})_{\mathrm{N}} \sim 12$, compared to the mantle domain $((\mathrm{Lu} / \mathrm{Sm}) \mathrm{N} \sim 2)$. Garnet mantle shows the highest LREE and a slightly negative slope for HREE. Garnet rims show the strongest depletion in MREE and a slightly lower HREE content compared to that of mantle.

\section{Geochronology and oxygen isotope}

\subsection{U-Pb dating and isotopes of zircon}

Fifty spots of twenty-seven zircon grains from eclogite sample 11AT06 have been analyzed to unravel the oxygen isotope composition and data the four growth domains (Table. 5; Th/U ratios vary between 0.001 to 0.005 ). Core domains give apparent ${ }^{206} \mathrm{~Pb} /{ }^{238} \mathrm{U}$ ages from 310.0 to $324.3 \mathrm{Ma}$, a mean 
Concordia age of $316.8 \pm 0.83 \mathrm{Ma}(\mathrm{MSWD}=1.01, \mathrm{n}=31)$ and a weighted mean age of $316.3 \pm 1.6 \mathrm{Ma}(\mathrm{MSWD}=0.71, \mathrm{n}=31$ ) (Fig. 10e). Similar results are found for the HREE enriched cores, with apparent ${ }^{206} \mathrm{~Pb} /{ }^{238} \mathrm{U}$ ages varying from 315.3 to $320.4 \mathrm{Ma}$, a mean Concordia age of $318.0 \pm 2.3 \mathrm{Ma}(\mathrm{MSWD}=2.7$, $\mathrm{n}=4)$ and a weighted mean age of $317.4 \pm 4.6 \mathrm{Ma}(\mathrm{MSWD}=0.25, \mathrm{n}=4)$ (Fig. 10d).

The mantle domain gives younger apparent ${ }^{206} \mathrm{~Pb} /{ }^{238} \mathrm{U}$ ages, from 297.2 to 307.1 Ma, a mean Concordia age of $303.1 \pm 1.7 \mathrm{Ma}(\mathrm{MSWD}=0.49, \mathrm{n}=7)$ and a weighted mean age of $303.1 \pm 3.3 \mathrm{Ma}(\mathrm{MSWD}=0.58, \mathrm{n}=7$ ) (Fig. 10f).

Owing to the low $U$ contents of the outer rims ( 5 of 8 analyzed spots have $U$ contents mostly ranging from 1 to $49 \mathrm{ppm}$; Table. 5), U-Pb results for this domain are presented on the Tera-Wasserburg plot and of poorer quality than the other domains. Common lead contents of the 8 analyzed spots are highly variable, with values of $f_{206}$ between $0.09 \%$ and $34.21 \%$ (Table. 5). The linear regression of the data points (MSWD $=0.81, \mathrm{n}=8$ ) gives a lower intercept age of $280.8 \pm 4.9 \mathrm{Ma}$ and the upper intercept with ${ }^{207} \mathrm{~Pb} /{ }^{206} \mathrm{~Pb}=0.381$ for the common $\mathrm{Pb}$ composition (Fig. 10g). The weighted mean ${ }^{206} \mathrm{~Pb} /{ }^{238} \mathrm{U}$ age of this rim domain is $280.5 \pm 4.3 \mathrm{Ma}\left(\mathrm{MSWD}=0.64, \mathrm{n}=8\right.$ ) using the ${ }^{207} \mathrm{~Pb}$-based common-lead correction (Williams, 1998) with the terrestrial $\mathrm{Pb}$ isotope composition from Stacey and Kramers (1975), which is consistent with the lower intercept age within errors. 
By contrast, oxygen isotope $\delta^{18} \mathrm{O}$ compositions measured in the four zircon domains are very similar (Fig. 10b; Table. 6), with most values ranging between $8.9 \%$ and $9.5 \%$ (Fig. 10b; mean value $=9.13 \pm 0.09 \%$, MSWD $=5.6, n=56$; Table. 6).

\subsection{Sm-Nd isotopic chronology}

Whole rock, omphacite and garnet (including core and rim) Sm-Nd isotopic data of the oriented eclogite sample 11AT06-2 are given in Table. 7. Sm and Nd concentrations of whole rock powder separates (1.68 and $4.26 \mathrm{ppm}$ respectively) are in good agreement with results obtained from whole-rock trace-elements analyses by ICP-MS (Table. 3). Whole rock and omphacite separates have ${ }^{147} \mathrm{Sm} /{ }^{144} \mathrm{Nd}$ ratios of $0.2841,0.2452$ and 0.2510 respectively. Garnet separates have a Sm/Nd ratio of about 2.13 and ${ }^{147} \mathrm{Sm} /{ }^{144} \mathrm{Nd}$ ratios of 1.2828 and 1.2843 , which are close to values reported for other SW Tianshan eclogites (Gao and Klemd, 2003). The WR-Omp-Grt isochron yields a Sm-Nd age of $312.1 \pm 2.4 \mathrm{Ma}(\mathrm{MSWD}=0.78$, Fig. 11), close to the Omp-Grt isochrone isochron $(311.9 \pm 2.6 \mathrm{Ma})$, with $\varepsilon N d(t)$ of $+8.5(t=$ ca. $312 \mathrm{Ma}$, Table. 7$)$. 


\section{Pressure-Temperature estimates}

\subsection{Multi-equilibrium thermobarometry}

P-T estimates for prograde equilibrium stages (using mineral inclusion pairs within garnet porphyroblast cores of sample 11AT06-1; Fig. 7d), peak eclogitic-facies and retrograde blueschist- to greenschist-facies recrystallizations (e.g., recrystallized tails of $\sigma$-type porphyroclasts in oriented samples 11AT06-2, GJ01-6 and GJ01-1; Fig.6a, 6b, 6c), are constrained using THERMOCALC average PT multi-equilibrium thermobarometry (Holland and Powell, 1998, 2011; version 3.33 with updated database tc-ds55). Average PT results and used representative mineral compositions are given in Table. S1.

P-T estimates of $495 \pm 20{ }^{\circ} \mathrm{C}$ and $2.75 \pm 0.05 \mathrm{GPa}$ were derived assuming equilibrium between garnet cores and inclusions of omphacite and amphibole (i.e., red square \#1 in Fig. 7d). Equilibrating omphacite inclusions and the garnet mantle (red square \#2 in Fig. 7d), in the vicinity of coesite inclusion, yield higher P-T estimates of $520 \pm 15{ }^{\circ} \mathrm{C}$ and $3.0 \pm 0.75 \mathrm{GPa}$ but with considerable pressure uncertainties. Lower $\mathrm{P}$ but higher $\mathrm{T}$ values, around $570 \pm 35{ }^{\circ} \mathrm{C}$ and $2.4 \pm 0.3 \mathrm{GPa}$, are obtained for garnet rims, considering an omp-grt-ph-amp equilibrium assemblage (i.e., red square \#3: Fig. 7d; Table. S1). Quartz (or coesite) was assumed to be present in all calculations and water activity was set to 1.0 . Lowering the water activity (e.g. $\left.\mathrm{a}_{\mathrm{H} 2 \mathrm{O}}=0.8\right)$ only 
results in a minor decrease in temperature $\left(\leq 15^{\circ} \mathrm{C}\right)$ and pressure $(\leq 0.05$ GPa).

P-T estimates obtained for the garnet rim, omphacite-amphibole-epidote \pm phengite assemblage marking the foliation of both sheared eclogitic samples (Figs. 6a, 6b; GJ01-6 and 11AT06-2) are $525 \pm 25{ }^{\circ} \mathrm{C} \& 2.0 \pm 0.15 \mathrm{GPa}$.

P-T conditions for the retrograde, blueschist- to (or) greenschist-facies equilibration stages associated with top-to-NNE shear senses (Fig. 6c, GJ01-1) were estimated from the mineral assemblage amphibole + paragonite + epidote + chlorite + feldspar (albite) at $380 \pm 50{ }^{\circ} \mathrm{C}$ and $1.0 \pm 0.2 \mathrm{GPa}$, and $420 \pm 25{ }^{\circ} \mathrm{C} \& 0.9 \pm 0.1 \mathrm{GPa}$.

\subsection{Phase equilibrium modeling}

Pseudosection modeling for sample 11AT06-1 was performed in the system MnNCKFMASHTO (Tables. 1, 2, 3), with excess $\mathrm{SiO}_{2}$ (i.e., quartz or coesite). $\mathrm{TiO}_{2}$ must be considered due to the presence of rutile and/or titanite in the matrix or as inclusions in porphyroblasts. The fluid phase in assumed to be pure $\mathrm{H}_{2} \mathrm{O}$ and was set in excess. $\mathrm{CO}_{2}$ was neglected as only small amounts of carbonate occur as thin secondary veins. $\mathrm{Fe}_{2} \mathrm{O}_{3}$ was set at $22.5 \mathrm{~mol} \%$ of total FeO according to XRF data (Table. 2).

In order to take into account the sequestration of elements induced by the growth zoning of garnet porphyroblast, effective bulk compositions were 
adjusted from XRF compositions by removing part of the garnet modal abundance, following the method of Carson et al. (1999). For the modelling of prograde and peak conditions (EBC-1), half of the modal abundance of zoned garnet (Warren and Waters, 2006; Wei et al., 2009) was removed from the XRF composition. For the retrograde path (EBC-2), garnet porphyroblasts were subtracted from the bulk-rock composition (see Table. 2 for XRF, EBC-1 and EBC-2 compositions).

The P-T pseudosections were calculated using the software Perple_X 6.68 (Connolly, 1990, 2005) and an internally consistent thermodynamic dataset (hp02ver.dat, Connolly and Kerrick, 2002; Holland and Powell, 2003) based on the effective recalculated bulk rock composition (EBC-1 and EBC-2; Table. 2). Mineral solid-solution models are Gt(HP) for garnet (Holland and Powell, 1998), Omph(GHP) for omphacite (Green et al., 2007), Amph (DP) for amphibole (Diener et al., 2007), Mica(CHA) for white mica (Coggon and Holland, 2002), Chl(HP) for chlorite (Holland and Powell, 1998), Ep(HP) for epidote/clinozoisite (Holland and Powell, 1998), and $\mathrm{H}_{2} \mathrm{O}-\mathrm{CO}_{2}$ fluid solution model is from Connolly and Trommsdorff (1991).

The pseudosection for sample 11AT06-1 is shown in Fig. 12b. It is dominated by tri- and quadrivariant fields with a few di- and quini- variant fields. P-T conditions were further constrained by comparing predicted garnet isopleths with measured garnet compositions (boxes on Fig. $12 \mathrm{~b}$ incorporate 
typical uncertainties on EMPA analyses, ca. 3\% to 5\%, Lifshin and Gauvin, 2001; Williams and Jercinovic, 2006).

Stage I, as defined by core-mantle zoning (i.e., garnet zoning from Grt-C to Grt-M3 in Fig. 7e; see compositions in Table. 3), is marked by an increase in both $\mathrm{T}$ and $\mathrm{P}$, from $2.55 \sim 2.70 \mathrm{GPa}$ and $495 \sim 505^{\circ} \mathrm{C}$ to $2.95 \sim 3.30 \mathrm{GPa}$ and $500 \sim 520^{\circ} \mathrm{C}$. Peak pressure $\left(P_{\max }\right)$ is constrained by using the garnet mantle compositions (corresponding to Grt-M2 to Grt-M4) which have the lowest $\mathrm{X}_{\mathrm{grs}}$ content, and coincide with the location of coesite inclusions (Figs. 7a-d).

Stage II is constrained by the mantle-rim zoning (corresponding to Grt-M4, Grt-M5 and Grt-R in Fig. 7d, Table. 3) and the mineral assemblage

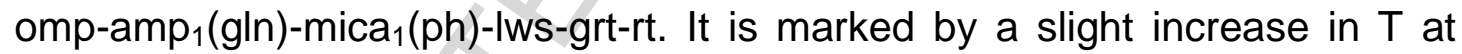
$550 \sim 560^{\circ} \mathrm{C}$ and a pressure decrease at 2.35 2.60 GPa, further constrained by the Si content of phengite included in garnet (3.43 p.f.u.; Table. 3). Later retrograde re-equilibration, based on the EBC-2 whole-rock composition, is estimated from measured $(\mathrm{Na})_{\mathrm{M} 4}$ contents in amphibole and $(\mathrm{Na})_{\mathrm{M} 4}$ isopleths modeled from pseudosection (Fig. 12c) at ca. $1.20 \mathrm{GPa}$ and $548^{\circ} \mathrm{C}$.

\section{Discussion}

\subsection{Nature of the protolith and P-T-(fluid) constraints}

The studied mafic eclogites show LREE-depleted and HREE-flat N-MORB 
patterns (Sun and McDonough, 1989), with enrichments in $\mathrm{Rb}, \mathrm{Ba}, \mathrm{U}, \mathrm{Pb}$, and Sr. $\delta^{18} \mathrm{O}$ values for multistage zircons $(\sim 9.13 \pm 0.09 \%$; Fig. 10b) with modelled bulk-rock $\delta^{18} \mathrm{O}_{\mathrm{p} \text { peak }}$ of ca. $8.47 \%$ (Table. 6 , oxygen fractionation factors from Zheng, 1991, 1993) are similar to those of typical altered ocean crust (AOC, 7.9 to $9.5 \%$ from Cocker et al., 1982; Miller and Cartwright, 2000), suggesting that the metamorphic zircons may have inherited the composition of the bulk (e.g., Rubatto and Angiboust, 2015) Some characteristic element patterns (e.g., in $\mathrm{Rb}$ vs $\mathrm{K}, \mathrm{Nb} / \mathrm{U}$ vs $\mathrm{U}, \mathrm{K} / \mathrm{Th}$ vs $\mathrm{Ba} / \mathrm{Th}$ and $\mathrm{Ba} / \mathrm{Nb}$ vs U/Nb diagrams, Bebout, 2007, 2013) suggest that the N-MORB protolith was later slightly enriched in LILE during metamorphism. By contrast, the meta-volcanosedimentary host rock yields an Upper Continental Crust-like trace-element and REE-distribution pattern, with notable $\mathrm{Nb}$ and Ta anomalies (Fig. 4).

The $\delta^{18} \mathrm{O}$ values of the various zircon domains are remarkably constant despite considerable multistage growth from ca. 318 to $280 \mathrm{Ma}$. This suggests that the rock system remained essentially closed over $\sim$ ca. $40 \mathrm{Ma}$, during metamorphic re-equilibration, with respective to potential external fluid infiltration, at both the $\mathrm{cm}$ - and $\mathrm{m}$-scale (zircon grains were collected from rock fragments from different parts of the outcrop), and/or that fluids were derived from (or equilibrated with) a similar source. External fluids derived from subduction-related lithologies would indeed have likely shifted the $\delta^{18} \mathrm{O}$ 
signature (unaltered slab mantle and oceanic crust $\sim 5.7 \%$, serpentinized slab mantle 1-8 \%o, metasediment 12-29 \%o from van der Straaten et al., 2012). We therefore hypothesize that external fluid infiltration was limited and/or $\delta^{18} \mathrm{O}$ was internally buffered (Martin et al., 2006; Martin et al., 2008).

The P-T evolution followed by mafic eclogites (Fig. 12) is characterized by burial along a typical subduction gradient $\left(\sim 7^{\circ} \mathrm{C} / \mathrm{km}\right)$ with a moderate heating (up to $50-80^{\circ} \mathrm{C}$ ) during decompression. This is consistent with recent results of thermodynamic modeling (Li et al., 2015; Li et al., 2016; Lü et al., 2009; Tian and Wei, 2013; Wei et al., 2003), though in contrast to some early claims of counterclockwise (Lin and Enami, 2006) or hairpin-shaped P-T trajectories (Gao et al., 1999).

Thermodynamic modelling of successive re-equilibration stages yield P-T

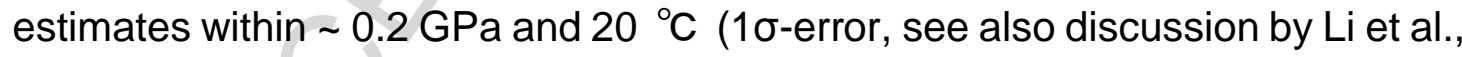
2016), considering uncertainties on solid solution models and thermodynamic properties (Dachs et al., 2012; Worley and Powell, 2000), effective bulk composition (Carson et al., 1999; Evans, 2004) and microprobe analyses (Lifshin and Gauvin, 2001; Williams and Jercinovic, 2006). Conventional thermobarometry give consistent and robust P-T results (Fig. 13a) but with larger uncertainties for the pressure peak (Fig. 12a, Table S1). When considering these uncertainties, most previous published P-T paths in fact will overlap (Fig. 13b, except for Li et al., 2015; Li et al., 2016; van der Straaten et 
al., 2008; Wei et al., 2003). Most studies concord on $T_{\max }$ conditions for peak burial in the range $510-570{ }^{\circ} \mathrm{C}$ (Fig. 13b). Our results $\left(520 \pm 30^{\circ} \mathrm{C}\right.$ for UHP peak burial and $550 \pm 30^{\circ} \mathrm{C}$ for the temperature peak) are consistent with the recent independent results obtained by Raman spectroscopy of carbonaceous matter (ca. $540 \pm 30^{\circ} \mathrm{C}$, Meyer et al., 2016).

Future studies should help clarify their contrasts in $P_{\max }$ estimates, which cluster in three distinct groups (dashed boxes; Fig. 13b): 1) a UHP group ranging from ca. 2.7 to 3.3 GPa (e.g., Tian and Wei, 2013; Wei et al., 2009; Xin et al., 2013) (and this study), 2) a HP group in the range of ca. 1.8-2.5 GPa (e.g., Beinlich et al., 2010; Du et al., 2014; Li et al., 2015; Li et al., 2016 ; Li et al., 2014; Meyer et al., 2016; Soldner et al., 2016) and 3) a blueschist-facies group ranging from ca. 1.3 to $1.9 \mathrm{GPa}$ (e.g., Gao et al., 1999; Klemd et al., 2002; van der Straaten et al., 2008; Wei et al., 2003).

\subsection{Linking garnet with zircon growth}

This section attempts to link the potential of garnet as thermobarometer (e.g., Konrad-Schmolke et al., 2008) with that of zircon as geochronometer (e.g., Rubatto, 2002) to closely tie U-Pb ages to metamorphic conditions and finally derive a precise P-T-time path. 
Figure 9b shows that REE patterns for successive garnet and zircon metamorphic growth are almost parallel, except for the zircon rim. Partitioning data for REE between zircon and garnet (Rubatto, 2002; Rubatto and Hermann, 2003) suggest that zircon preferentially sequesters $Y$ and HREE over garnet, with D-values of $2-4$ (Fig. 14a). Data show that only the zircon high HREE core and/or core domains (and not the zircon mantle and rim) have higher HREE contents than garnet (Fig. 14b, Table. 4) and may therefore have equilibrated with it.

Zircon high-HREE cores may have co-crystallized either with the garnet core or mantle domains (Fig. 14b), but the $D^{Y+H R E E s}$ zrn/grt pattern of the second option is more similar to the one reported in eclogite vein by Rubatto and Hermann (2003). For the zircon core domain, the most likely candidate would be the garnet rim. We thus tentatively propose (Figs. 14c, 15) that zircon high-HREE core grew in equilibrium with the garnet mantle at $~ c a .318 \mathrm{Ma}$ at UHP conditions ( ca. 2.6-3.1 GPa; Grt-M1 to M2 stages with coesite inclusions; Fig. 7), while zircon core grew in equilibrium with the garnet rim at ca. $316 \mathrm{Ma}$ ( ca. 2.3-2.7 GPa; Grt-M5 to R stage).

The zircon mantle domain ( ca. 303 Ma, Fig. 10f), with similar but lower HREE patterns (Fig. 9a), could have inherited its HREE content from the partial resorption of garnet (and/or zircon cores, i.e., Degeling et al., 2001), while garnet abundance was still buffering the HREE budget. By contrast, the 
different REE pattern of the last zircon rim overgrowth ( ca. 280 Ma, Fig. 10g), hints to the breakdown of another Zr-bearing mineral during greenschist/blueschist-facies exhumation, possibly rutile (Kohn et al., 2015; Lucassen et al., 2010). Similar multi-stage zircon growth from the Dabie mountain (but with zircon from separate eclogite and quartz vein, Liu et al., 2014b; Zheng et al., 2007) was interpreted as a witness of channelized fluid flow during exhumation.

\subsection{Age constraints and regional-scale tectonic implication}

Based on garnet-zircon equilibrium, ages of $~$ ca. 318 and ca. 316 Ma can be ascribed to the peak burial (UHP) and peak temperature (HP) metamorphic stages, respectively (Figs. $14 \mathrm{c}$ and 15). Whole rock-grt-omp and grt-omp Sm-Nd isochrons give additional, consistent age constraints at $\sim 312 \pm 2.5$ (Fig. 11; Table. 7). Although experimentally determined closure temperatures for $\mathrm{Nd}$ diffusion differ in garnet $\left(\sim 500-850^{\circ} \mathrm{C}\right.$, Li et al., 2000$)$ and omphacite $\left(\sim 1050^{\circ} \mathrm{C}\right.$, Sneeringer et al., 1984), questioning Nd equilibrium between these phases at a peak temperature of $530 \pm 30^{\circ} \mathrm{C}$, consistent mineral pair and whole rock Sm-Nd isochron were reported for similar fine-grained eclogites from distinct localities in the Dabie mountains (Li et al., 2000).

This WR-garnet-omphacite Sm-Nd age of ca. $312 \mathrm{Ma}$ (Fig. 11, Table. 7) can therefore be treated as constraining the post-peak eclogite-facies 
deformation event coeval with omphacite growth in the matrix (Fig. 6a, 6b), slightly after or coeval with the growth of zircon cores in equilibrium with garnet rims (i.e., ca. $316 \mathrm{Ma}$ ). These age constraints are broadly consistent with a recent Sm-Nd WR-grt-omp age of $~ 307 \pm 11 \mathrm{Ma}$ interpreted as dating the timing of HP metamorphism (Du et al., 2014) and a Sm-Nd WR-grt-gln age of $318.4 \pm 3.9 \mathrm{Ma}$ for a blueschist equilibrated close to HP peak metamorphism (Soldner et al., 2016). Ages between 318 and $312 \mathrm{Ma}$ are also consistent with the $320.4 \pm 3.7 \mathrm{Ma}$ zircon-rim U-Pb age obtained on coesite-bearing meta-volcanosedimentary rocks (Xin et al., 2013) and with the $315.2 \pm 1.6 \mathrm{Ma}$ garnet-multi-point Lu-Hf age obtained for eclogites (Klemd et al., 2011).

Overall, the present study allows to conclude that $315 \pm 5$ Ma can be taken as a reliable value for the attainment of HP to UHP conditions in the Chinese Southwestern Tianshan UHP-HP/LT metamorphic complex. The dispersion of $\mathrm{Ar} / \mathrm{Ar}$ ages (Fig. 16b, Gao and Zhang, 2000; Klemd et al., 2005; Wang et al., 2010; Xia et al., 2015) may therefore be due to a problem of excess argon, at least in some eclogite/blueschist samples. Indeed the same outcrop yielded very distinct Ar-Ar plateau ages (e.g., $401 \pm 1$ and $364 \pm 1$ Ma by Gao and Zhang, 2000 versus ca. 320 Ma by Klemd et al. 2005), and similar ages were obtained for $\mathrm{Rb} / \mathrm{Sr}$ and $\mathrm{Ar} / \mathrm{Ar}$ ages by Klemd et al. (2005), for which white mica closure temperatures (if strictly under fluid-assisted recrystallization-free assuming) differ by $100{ }^{\circ} \mathrm{C}$ or more (Li et al., 1994; Ruffet et al., 1997; Villa, 
1998; Villa and Puxeddu, 1994).

The $303 \mathrm{Ma}$ age derived from zircon mantle recrystallization (Fig. 10f) is here taken as a minimum age for the garnet-free or garnet resorption greenschist-facies metamorphism. This conclusion is strengthened by a greenschist-facies Ar-Ar plateau age of $\sim 293.1 \pm 1.7$ Ma reported by Xia et al. (2015). Later recrystallization of zircon rims at $\sim 280 \mathrm{Ma}$, though of poor quality (Fig. 10g) could correspond to the late exhumation movements, as similar ages were reported for the extensive ductile strike-slip deformation of the Southwestern Central Tianshan Suture zone (i.e., de Jong et al., 2009; Laurent - Charvet et al., 2003). Note that late, post-exhumation rodingitization was constrained at $291 \pm 15.0 \mathrm{Ma}$ ( $\mathrm{Li}$ et al., 2010c) and that crosscutting, undeformed leucogranites were dated at $\sim 284.9 \pm 2.0 \mathrm{Ma}$ (Gao et al., 2011).

These age constraints point to decreasing exhumation velocities, from ca. $12.0 \pm 6.5 \mathrm{~mm} / \mathrm{yr}$ for early UHP to HP exhumation (if $<2 \mathrm{Ma}$ ) to $3.6 \pm 2.0 \mathrm{~mm} / \mathrm{yr}$ for blueschist-facies exhumation (within ca. $13 \mathrm{Ma}$ ) and $0.8 \pm 0.4 \mathrm{~mm} / \mathrm{yr}$ for greenschist-facies exhumation (within ca. $22 \mathrm{Ma}$ ). The average exhumation rate, ca. $2.6 \mathrm{~mm} / \mathrm{yr}$, falls within the range of $1-5 \mathrm{~mm} / \mathrm{yr}$ for exhumed oceanic rocks worldwide (Agard et al., 2009). Importantly, the timing of HP-UHP metamorphism appears very restricted (at $315 \pm 5 \mathrm{Ma}$; i.e., < $10 \mathrm{Ma}$ ) compared to the likely duration of active subduction (> 50-100 My, since an oceanic 
domain existed in the region from at least $\sim 22 \pm 10 \mathrm{Ma}$ to ca. $280-300 \mathrm{Ma}$, Li et al., 2010c).

Although this study focuses on a single key exposure, a simple geodynamic reconstruction is provided (Figs. 17a, 17b) to set back our results in a tentative evolution of the Chinese Southwestern Tianshan metamorphic complex. HP-UHP/LT rocks were detached or exhumed after their peak burial only at about $315 \pm 5 \mathrm{Ma}$ (Figs. 16a, 16b) and brought back to the surface to greenschist-facies conditions between ca. 310 and 300 Ma (Fig. 17b). Pervasive north-trending shear senses deduced from eclogite-, blueschist- and greenschist-facies recrystallizations (this study, Fig. 6, see also in Lin et al., 2008; Wang et al., 2010) are interpreted to result from southwest-trending extrusion of the AMC (Figs. 17a, 17b).

At present, thorough large-scale structural studies and/or extensive P-T(-t) mapping across the whole HP/UHP complex are still missing to assess whether the ponctated exhumation at $315 \pm 5 \mathrm{Ma}$ is associated with chaotic block-in-matrix mixing, with heterogeneous P-T and/or fluid conditions (e.g., extremely complex zoning of both garnet and amphibole, Li et al., 2016) or to accretion of tectonic slices of volcanosedimentary material hosting stripped pieces from the seafloor (i.e., mafic meta-volcanics). 


\section{Conclusions}

This study provides P-T-radiometric-isotopic constraints on several eclogitic samples from a key coesite-bearing location in the Chinese Southwestern Tianshan UHP-HP/LT metamorphic complex. Together with an exhaustive review of available P-T (-time) constraints for the area, the following conclusions can be drawn from these new data:

(1) Mafic eclogites have slightly LILE-enriched N-MORB like features with

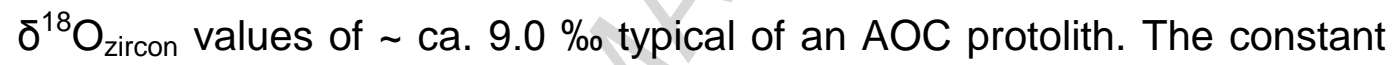
$\delta^{18} \mathrm{O}$ values for the successive zircon growths suggest a metamorphic system closed (or very limited) to external fluid infiltration.

(2) Thermodynamic modeling permits a complete recovery of their P-T trajectory from pre-peak burial to UHP conditions $(\sim 2.95 \mathrm{GPa} \pm 0.2$ and $\left.510^{\circ} \mathrm{C} \pm 20\right)$ and later exhumation. REE partitioning between multistage zircon and garnet growth domains allows for a critical assessment of the P-T-time path: the ca. $318 \mathrm{Ma}$ and $316 \mathrm{Ma}$ zircon ages are tied to UHP and HP metamorphism, respectively, along with a consistent ca. $312 \mathrm{Ma} \mathrm{Sm-Nd}$ age for HP eclogite-facies deformation. Thus, peak burial can be constrained at about $315 \pm 5 \mathrm{Ma}$. These P-T-t constraints point to decreasing exhumation velocities, from ca. $12.0 \pm 6.5 \mathrm{~mm} / \mathrm{yr}$ for early UHP to HP exhumation to $3.6 \pm 2.0 \mathrm{~mm} / \mathrm{yr}$ for blueschist facies exhumation and $0.8 \pm 0.4 \mathrm{~mm} / \mathrm{yr}$ for greenschist facies exhumation . 
(3) The comparison of P-T (-time) estimates between this study and the compilation of previous works outlines the existence of a short-lived detachment of subducted eclogites ( $<10 \mathrm{Ma}$ ) with respect to the "long-term" subduction duration (> 50-100 Ma).

\section{ACKNOWLEDGMENTS}

This study was essentially funded by the National Natural Science Foundation of China (41390440, 41390445, 41025008). Additional support was provided by project "Zooming in between plates" (Marie Curie International Training Network) to Prof. Philippe Agard. We would like to thank the editor Prof. Marco Scambelluri and anonymous reviewers for their constructive comments that greatly helped in improving the article. We further thank He Li and Bingyu Gao for helping the major and trace elements analysis, Qian Mao and Reiner Klemd for helps and data processing during microprobe analyses, Qiuli, Li, Yu Liu, Guoqiang Tang and Jiao Li for helps during SIMS zircon U-Pb dating and oxygen analyse, Yueheng Yang for help during zircon and garnet in situ trace elements analyse, and Zhuyin Chu for help during Sm-Nd isotope analyse. 


\section{APPENDIX}

\section{Analytical methods}

\section{Bulk-rock analyses}

Four bulk-rock chemical analyses were performed at the Institute of Geology and Geophysics, Chinese Academy of Sciences (IGGCAS) on three samples from one eclogite outcrop (see location in Fig. 4; 11AT06-1, 11AT06-2 and GJ01-6), and one sample from the wall-rock mica schist $\sim 3$ meters away (GJ01-1). Major oxides were determined by a PHILLIPS PW1480 X-ray fluorescence spectrometer (XRF) on fused glass discs. Loss on ignition (LOI) was measured after heating to $1,000{ }^{\circ} \mathrm{C}$. Uncertainties for most major oxides are ca. $2 \%$, for $\mathrm{MnO}$ and P2O5 ca. $5 \%$, and totals are within $100 \pm 1$ wt. $\%$. Whole rock $\mathrm{Fe}_{2} \mathrm{O}_{3}$ content is constrained by potassium permanganate titration. Trace element concentrations were analyzed by inductively coupled plasma mass spectrometry (ICP-MS) using a Finnigan MAT ELEMENT spectrometer at the IGGCAS. The detailed analytical procedure is identical to that used by Qian et al. (2006). Relative standard deviations (RSD) are within $\pm 10 \%$ for most trace elements but reach $\pm 20 \%$ for $\mathrm{V}, \mathrm{Cr}$, Co, Ni, Th and $\mathrm{U}$ according to analyses of rock standards. Detail major and trace elements analyses are 
presented in Table. 2.

\section{Mineral major elements}

In situ major element compositions of garnet and inclusion minerals were obtained from polished thin sections by electron microprobe analyses at the IGGCAS with the use of JEOL JXA 8100. Quantitative analyses were performed using wavelength dispersive spectrometers with an acceleration voltage of $15 \mathrm{kV}$, a beam current of $15 \mathrm{nA}$, a $3 \mu \mathrm{m}$ beam size and $30 \mathrm{~s}$ counting time. Natural minerals and synthetic oxides were used as standards, and a program based on the ZAF procedure was used for data correction. Representative microprobe analyses for pseudosection modeling and for Thermocalc averagePT calculations are presented in Table. 3 and Table. 8, respectively.

\section{Mineral trace elements}

In situ trace element analyses of zoned garnet and zircon were performed by LA-ICP-MS at the IGGCAS with a single collector quadrupole Agilent 7500a ICM-MS, equipped with an UP193Fx argon fluoride New Wave Research Excimer laser ablation system. The glass reference material NIST SRM 610 and NIST SRM 612 were used as standards for external calibration. LA-ICP-MS measurements were conducted using a spot size diameter of 40 to $60 \mu \mathrm{m}$, a laser frequency of $15 \mathrm{~Hz}$ and $0.63 \mathrm{GW} / \mathrm{cm} 2$ and a fluence of 3.32 
$\mathrm{J} / \mathrm{cm} 2$. Acquisition time was $20 \mathrm{~s}$ for the background and $120 \mathrm{~s}$ for the mineral analyses. The Ca-content of garnet determined by EMP analyses and the Si-content of zircon constrained by standard zircon 91500 were used as internal standards. Reproducibility and accuracy, which were determined for NIST SRM 610 and NIST SRM 612, are usually $<8 \%$ and $<6 \%$. Trace element concentrations were then calculated using GLITTER Version 3 (Van Achterbergh et al., 1999). Representative average trace element data of the relevant garnet and zircon domains are given in Table. 4.

\section{Raman analyses}

In order to identify coesite inclusions in garnet or small high-pressure mineral inclusions in zircon (e.g. omphactie or rutile), Raman spectroscopy was performed at IGGCAS using a Renishaw Raman MKI-1000 system equipped with a CCD detector and an Ar ion laser. The laser beam with a wavelength of $514.5 \mathrm{~nm}$ was focused on the coesite inclusion through $50 \times$ and $100 \times$ objectives of a light microscope. The laser spot size was focused to $1 \mu \mathrm{m}$. The reproduction of spectra for the same spot is better than $0.2 \mathrm{~cm}^{-1}$.

\section{Sm-Nd isotope chronology analyses}

Sm-Nd isotopic analyses were obtained at the Institute of Geology and Geophysics, Chinese Academy of Sciences, Beijing. $100 \mathrm{mg}$ of samples were first mixed with ${ }^{149} \mathrm{Sm}-{ }^{150} \mathrm{Nd}$ diluent, dissolved afterwards in a purified 
$\mathrm{HF}-\mathrm{HClO}^{4}-\mathrm{HNO}^{3}$-mixture, and finally heated on an electric hot plate for a week. Separation and purification of bulk REE were conducted by a silica-column with an AG50W-X12 exchange resin (200-400 mesh, 2ml), those of Sm and Nd by a silica-column with Teflon powder $(1 \mathrm{ml})$ as exchange medium. Isotopic ratios of Sm and Nd were measured using a Finnigan MAT-262 thermal ionization mass spectrometer. Nd isotopic data of unknowns were normalized to ${ }^{146} \mathrm{Nd} /{ }^{144} \mathrm{Nd}$ of 0.7219 , and corrected using Ames $\left({ }^{143} \mathrm{Nd} /{ }^{144} \mathrm{Nd}=0.512138\right)$ as external standard. Errors in element concentrations and $147 \mathrm{Sm} / 144 \mathrm{Nd}$-ratios are less than $0.5 \%(2 \sigma) . \mathrm{Sm}-\mathrm{Nd}$ data for the studied sample is shown in Table. 7.

\section{$\mathrm{U}-\mathrm{Pb}$ isotope chronology and Oxygen isotope of zircon}

For the preparation of zircon study, and considering the relative low $\mathrm{Zr}$ content (only ca. $50 \mathrm{ug} / \mathrm{g}$ ) of this N-MORB type meta-basalt (Table. 2), about 100 kilograms eclogite were sampled from outcrop (detailed sampling locations are shown in Figs. 3a, 3c. 11AT06-1, ca. 40 kg, sampled in 2011; 11AT06-2, ca. $60 \mathrm{~kg}$, sampled in 2013), and approximately 500 zircon grains were collected and mounted in three different epoxy mounts. Fifty point analyses on different zircon domains from grains selected via $C L$ images were chosen for investigating the $\mathrm{U}-\mathrm{Pb}$ isotopic chronology and Oxygen isotopic composition of the potential multistage growth of zircon. 
Zircon grains of sample 11AT06 were prepared by conventional crushing techniques and were hand-picked, mounted onto epoxy resin disks and polished with $0.25 \mu \mathrm{m}$ diamond paste. The zircon grains and zircon standards (Plesovice, Peng Lai and Qing Hu zircon were used here as standards) were mounted in epoxy mounts and then polished to section the crystals in half. Assessment of zircon grains and the choice of analytical sites were based on the transmitted and reflected light microscopy and cathodoluminescence (CL) images. CL imaging was processed on the LEO145VP scabbubg electron microscope with a Mini detector at the Institute of Geology and Geophysics, Chinese Academy of Sciences in Beijing (IGGCAS). The mount was vacuum-coated with high-purity gold prior to secondary ion mass spectrometry (SIMS) analyses. Measurements of $\mathrm{U}, \mathrm{Th}$ and $\mathrm{Pb}$ were conducted using the Cameca IMS-1280 SIMS. U-Th-Pb ratios and absolute abundances were determined relative to the standard zircon 91500 (Wiedenbeck et al., 1995), analyses of which were interspersed with those of unknown grains, using operating and data processing procedures similar to those described by Li et al. (2009). A long-term uncertainty of $1.5 \%$ (1 RSD) for ${ }^{206} \mathrm{~Pb} /{ }^{238} \mathrm{U}$ measurements of the standard zircons was propagated to the unknowns (Li et al., 2010a) despite that the measured ${ }^{206} \mathrm{~Pb} /{ }^{238} \mathrm{U}$ error in a specific session is generally around $1 \%$ ( 1 RSD) or less. Measured compositions were corrected for common $\mathrm{Pb}$ using non-radiogenic ${ }^{204} \mathrm{~Pb}$. Further details on instrument 
parameters, analytical method, calibration and correction procedures can be found in (Li et al., 2010b). Results of U-Pb isotopic chronology of zircon for sample 11 AT06 are listed in Table. 5.

Oxygen isotope analyses at the exact locations of $\mathrm{U}-\mathrm{Pb}$ isotope zircon were also processed with the use of the Cameca IMS-1280 SIMS at IGGCAS. After $\mathrm{U}-\mathrm{Pb}$ dating, the mount was carefully repolished for the $\mathrm{O}$ isotope analyses. The Gaussian focused $\mathrm{Cs}+$ ions are used as a primary beam to sputter zircon for O-isotope analyses. The primary beam size is $\sim 10$ um in diameter, and 2.5-3 nA in intensity. The ${ }^{16} \mathrm{O}$ and ${ }^{18} \mathrm{O}$ ions are detected simultaneously by two Faraday cups, and the currents are amplified by $10^{10}$ ohms and $10^{11}$ ohms resistors, respectively. Each spot analysis consists of pre-sputtering, beam centering in apertures, and a signal collecting process. A single spot analysis lasts 3 mins, including 2 mins for pre-sputtering and centering the secondary beam, and $1 \mathrm{~min}$ to collect 16 cycles of ${ }^{16} \mathrm{O}$ and ${ }^{18} \mathrm{O}$ signals. Oxygen isotopes were measured using the multi-collection mode. The instrumental mass fractionation (IMF) was corrected using an in-house zircon standard Penglai with $\delta^{18}$ OVSMOW $=5.31 \pm 0.10 \%$ (Li et al., 2010d). The measured ${ }^{18} \mathrm{O} /{ }^{16} \mathrm{O}$ ratios were normalized to the VSMOW composition, then corrected for IMF as described in (Li et al., 2010b): IMF $=\delta^{18} \mathrm{O}_{\mathrm{M}} \quad \delta^{18} \mathrm{O}_{\text {Standard, }}$ and $\delta^{18} \mathrm{O}_{\text {Sample }}=\delta 18 \mathrm{O}_{\mathrm{M}}+\mathrm{IMF}$, where $\delta^{18} \mathrm{O}_{\mathrm{M}}=\left[\left({ }^{18} \mathrm{O} /{ }^{16} \mathrm{O}\right)_{\mathrm{M}} / 0.0020052-1\right]$ $\times 1000(\%)$ and $\delta^{18} \mathrm{O}_{\text {Standard }}$ is the recommended $\delta^{18} \mathrm{O}$ value for the zircon 
standard on the VSMOW scale. Corrected $\delta^{18} \mathrm{O}$ values are reported in the standard per mil notation with $2 \sigma$ errors. Analytical conditions, instrumentation and operation conditions are similar to Li et al. (2010d); Tang et al. (2015), and the results of oxygen isotope for zircon in sample 11AT06 are listed in Table. 6.

\section{FIGURE AND TABLE CAPTIONS}

Fig. 1: Simplified geological map of (a) the Chinese Western Tianshan and (b) close-up map for the area (modified after Gao et al. (1999) with tagged locality distribution of previous radio-chronological data. Red stars mark the location of UHP reports (the finding of coesite). Green overlays indicate the inferred distribution of eclogites based on literature data. The dashed blue box marks the sample location (Fig. 3) of this study. Letters on the lower-left corner of the age boxes refer to lithology: "M" for mafic (typical eclogite), "m" for matrix (mainly meta-volcanic sediment with abundant amphibole) and " $m$ " for micaschist (mainly felsic). Numbers on the upper-right corner of the boxes correspond to publications listed in Table. S2. \#1: blueschist (used to be eclogite), Grt-GIn-WR Lu-Hf \& Grt-Gln-WR Sm-Nd isochron ages, Soldner et al. (2016); \#2: granitoids, zircon SHRIMP age, (LePu et al., 2011); \#3: calc-Alkaline granite and granodiorite, Zircon LA-ICP-MS and SHRIMP age, Gao et al. (2009); \#4: eclogite, rutile SIMS U-Pb age, Li et al. (2011); \#5: 
eclogite, Grt-Omp-WR Sm-Nd isochron age, (Du et al., 2014); \#6: eclogite, Grt-Omp-WR Lu-Hf isochron age, Klemd et al. (2011); \#7: eclogite, zircon SHRIMP U-Pb age, Zhang et al. (2007); \#8: blueschist, crosstie \& phengite Ar-Ar plateau age, Gao and Klemd (2003); \#9: eclogite, zircon SHRIMP U-Pb age, Zhang et al. (2007); \#10: eclogite \& micaschist, white-mica Ar-Ar plateau\& $\mathrm{Rb}-\mathrm{Sr}$ isochron age, Klemd et al. (2005); \#11: eclogite, zircon SHRIMP U-Pb age, Zhang et al. (2007); \#12: eclogite, glaucophane \& white-mica Ar-Ar plateau age, Gao and Zhang (2000); \#13: blueschist, white-mica Ar-Ar plateau age, Gao and Zhang (2000); \#14: blueschist, glaucophane Ar-Ar plateau age, Gao and Zhang (2000); \#15: Blueschist, white-mica \& glaucophane Ar-Ar plateau age, (Gao et al., 2006); \#16: eclogite, Grt-Gln Sm-Nd isochron age, Gao and Klemd (2003); \#17: eclogite, zircon SHRIMP U-Pb age, Zhang et al. (2007); \#18: micaschist, zircon SHRIMP U-Pb age, Xin et al. (2013); \#19 : eclogite, zircon SHRIMP U-Pb age, Su et al. (2010); \#20: eclogite (Terrigenous detrital material), zircon SIMS U-Pb age, Liu et al. (2014a);

Fig. 2: Compilation of age data (a) as a function of estimated $P_{\max }$ and (b) shown as a histogram (detail see Table. S2). Sources listed in the captions of Fig. 1 and Table. S2. "1": $P_{\max }$ range for previous "blueschist" ages lacking precise P-T constraint; "2": same for eclogites; "3": range of zircon U-Pb data from SP leucogranite dikes (Gao et al., 2011); "4": range of zircon (inherited core) U-Pb data from regional rodingite (Li et al., 2010c). 
Fig. 3: (a) Schematic outline of the studied outcrop; (b) field view of the sampling and (c) location of the samples in the layered eclogite.

Fig. 4: Whole-rock discrimination diagrams for the samples: (a) chondrite-normalized REE patterns, (b) primitive mantle-normalized spider diagram and (c) $\mathrm{Th} / \mathrm{Yb}$ versus $\mathrm{Nb} / \mathrm{Yb}$ diagram (Pearce, 2008). Reference curves for average N-MORB and OIB from Sun and McDonough (1989), and from Rudnick and Gao (2003) for upper continental crust.

Fig. 5: Mineral assemblages and microstructures of the studied eclogites. $(a, b)$ Typical eclogitic facies mineral assemblages in sample 11AT06: subhedral-anhedral omphacite matrix grains (partially replaced by euhedral-subeuhedral amphibole porphyroblasts and subeuhedral paragonite grains), idioblastic garnet porphyroblasts and minor rutile grains in the omphacite matrix (cross-polar view). (c,d) Idioblastic garnet porphyroblasts partially replaced by subhedral epidote group minerals. (e) typical texture of studied garnet porphyroblast (same as in Figs. 7a, 7d), with abundant mineral inclusions (showed both in cross polar and plane polar view) within the core-mantle domain and slightly replaced by chlorite. (f) Moderately foliated omphacite matrix in the oriented sample of the studied layered eclogite (cross polars). (g) Occurrence of rutile inclusions in paragonite porphyroblast. Note the amphibole with a glaucophane core (pale blue) and a more barroisitic greenish rim. (h) Glaucophane inclusions in the core of a garnet porphyroblast. 
(i) Omphacite inclusions in a paragonite porphyroblast. Mineral abbreviations: grt, garnet; omp, omphacite; brs, barroisite; gln, glaucophane; ph, phengite; pg, paragonite; ep, epidote; zo, zoisite; qz, quartz; rt, rutile; pyr, pyrite; chl, chlorite. Fig. 6: Thin-section scale shear senses in eclogite and greenschist facies for the UHP eclogite and its meta-volcano-sedimentary host-rock, respectively. (a, b) Foliated omphacite matrix and $\sigma$-type garnet porphyroclasts with epidote, omphacite and phengite recrystallized tails. (c) Foliated albite and amphibole matrix, and $\sigma$-type fractured porphyroclasts of garnet with quartz, albite, paragonite and amphibole recrystallized tails. Gray solid-circles show the location of EMPA analyses for Thermocalc averagePT calculations (see Table S1). Mineral abbreviations as for figure 5.

Fig. 7: Garnet porphyroblast and mineral inclusions: (a) BSE imaging and location of mineral inclusions in the garnet core-mantle domain (dashed blue boxes shown in Fig. S2); (b) Raman spectrum of the analysed coesite inclusion; (c) Close-up view of the coesite inclusion in the garnet mantle domain; (d) Sketch of mineral inclusion distribution and location of analyses. Black dashed circles: laser-ICP-MS spots (see Fig. 9b); thick dashed line: EMPA profile (see Fig. 7e; Table. 3); red dashed rectangles: region with coexisting mineral inclusions chosen for thermocalc averagePT calculations; (e) Composition profile across the center of the studied garnet porphyroblast (Fig. 7a, 7d); (f) composition of sodic clinopyroxene (Morimoto, 1988) outlining the distinct 
omphacite generations; (g) Chemical composition of amphiboles in studied eclogite after Hawthorne and Oberti (2006). Mineral abbreviations as for figure 5.

Fig. 8: Cathodoluminescence imaging and sketches of analyzed zircon grains, showing multistage growth features. The location of U-Pb, REEs, $\delta^{18} \mathrm{O}$ analyses is shown by red solid-ellipse $\left(10 \times 15\right.$ um $^{2}$ beam-size via SIMS), orange dash-circle (with $40 \times 40$ um $^{2}$ beam-size via Laser-ICP-MS) and blue solid-circle (with $20 \times 20$ um $^{2}$ beam-size via SIMS) respectively (see Table. 5). Other zircon grains are shown in Fig. S3.

Fig. 9: Chondrite-normalized (Sun and McDonough, 1989) REE abundances of the various zircon (a) and garnet domains (b) (Table. 4). Overlays outline the compositional range of the various generations observed (taking into account the 1- $\sigma$ uncertainty). For a better comparison of REEs patterns, average patterns of core, core with high HREEs, mantle and rim domains of zircon are labelled 1, 2, 3, 4. Circled numbers 1, 2, 3 in Fig. 9b correspond to REE patterns of the core, mantle and rim of garnet (e.g. marked as grt-c, R, 02), identified as potentially coexisting with metamorphic zircon domain (rim), in the eclogite-facies micaschist of Rubatto (2002).

Fig. 10: Results of SIMS U-Pb isotopic dating and $\delta^{18} \mathrm{O}$ compositions for various zircon domains: (a, b) All SIMS analyses of the four zircon domains. (c) concentrations of $\delta^{18} \mathrm{O}(\%)$ versus $\mathrm{U}-\mathrm{Pb}$ ages of multistage zircon domains. 
The results of SIMS U-Pb age and $\delta^{18} \mathrm{O}$ composition of ,respectively, (d, number "1" with square in Fig. 10b) zircon core domain with high HREEs content (corresponding to green contour in Fig. 9a), (e, number "2" with square in Fig. 10b) zircon core domain (corresponding to red contour in Fig. 9a), (f, number "3" with square in Fig. 10b) zircon mantle domain (corresponding to blue contour in Fig. 9a) and (g, number "4" with square in Fig. 10b) zircon rim domain (corresponding to yellow contour in Fig. 9a) are listed in Tables. 5 and 6.

Fig. 11: WR-garnet-omphacite Sm-Nd isochron age for the oriented sample (11AT06-2; Table. 7).

Fig. 12: P-T estimates for the studied UHP eclogites, inferred from Perple_X pseudosection modeling and Thermocalc averagePT calculation: (a) compilation of Thermocalc averagePT results (Table. S1); the pink arrow features the estimated trajectory, taking into account the uncertainties from avPT calculations. (b) P-T pseudosection in the system NMnCKFMASHTO for the studied UHP eclogite (effective bulk composition in Table. 2). Seven spots across the core-rim EMPA profile (Fig. 7e; Table. 3) were used to estimate PT conditions based on calculated isopleths. Blue boxes also consider ca. $5 \%$-calculated uncertainties. White arrow: estimated P-T trajectory from pseudosection modelling; dashed box: estimation of retrograde P-T conditions from the $(\mathrm{Na})_{\mathrm{M} 4}$ content of matrix amphibole. Mineral abbreviations as in figure 
5.

Fig. 13: P-T trajectory estimates from this study (a) and previous works (b). See text for details. Brown boxes mark: estimates of peak metamorphism for UHP mica schist (Wei et al. (2009) Xin et al. (2013). Light-green box: peak metamorphic UHP conditions for metabasite from Tian and Wei (2013). Ages shown in figure 13a are discussed in section 9.3.

Fig. 14: (a-b) Patterns of trace element distribution coefficients between various possibly coexisting zircon and garnet domains. (c) sketch summarizing the various growth zones observed in zircon and garnet.

Fig. 15: Sketch depicting the petrologic evolution of mineral growth within metabasalts and inferred mobility of elements (mainly REEs) within the garnet-zircon-matrix metamorphic system during subduction and exhumation.

Fig. 16: Previous radiometric data (see Table. S2) and results from this study place constraints on the main tectonic stages for the area (i.e., detachment, exhumation, etc), as well as on exhumation rates.

Fig. 17: Simplified geodynamic cartoon setting back the studied samples and the overall time constraints inferred from this study within the evolution of the Chinese Southwestern Tianshan HP-UHP/LT metamorphic belt.

Table 1: Mineral modes in the studied samples (vol.\%).

Table 2: Bulk rock major- and trace-element compositions of layered eclogite 
samples and their meta-volcano-sedimentary host rock. Estimated effective bulk rock compositions for pseudosection modelling are indicated (EBC1 and EBC2).

Table 3: Representative microprobe analyses.

Table 4: Average Laser-ICP-MS trace-element compositions of various garnet and zircon domains.

Table 5: SIMS zircon U-Pb isotopic data.

Table 6: SIMS zircon oxygen isotopic data and modeled mineral \& bulk-rock oxygen isotopic data at peak pressure conditions.

Table 7: TIMS Sm-Nd isotopic data.

\section{REFERENCES}

Agard, P., Yamato, P., Jolivet, L., and Burov, E., 2009, Exhumation of oceanic blueschists and eclogites in subduction zones: timing and mechanisms: Earth-Science Reviews, v. 92, no. 1, p. 53-79.

Allen, M., Windley, B., and Zhang, C., 1993, Palaeozoic collisional tectonics and magmatism of the Chinese Tien Shan, central Asia: Tectonophysics, v. 220 , no. 1 , p. $89-115$.

Bebout, G. E., 2007, Metamorphic chemical geodynamics of subduction zones: Earth and Planetary Science Letters, v. 260, no. 3-4, p. 373-393.

-, 2013, Metasomatism in Subduction Zones of Subducted Oceanic Slabs, Mantle Wedges, and the Slab-Mantle Interface, p. 289-349.

Beinlich, A., Klemd, R., John, T., and Gao, J., 2010, Trace-element mobilization during Ca-metasomatism along a major fluid conduit: Eclogitization of blueschist as a consequence of fluid-rock interaction: Geochimica et Cosmochimica Acta, v. 74, no. 6, p. 1892-1922. 
Bucher, K., and Grapes, R., 2011, Petrogenesis of metamorphic rocks, Springer Science \& Business Media.

Burov, E., Francois, T., Yamato, P., and Wolf, S., 2014, Mechanisms of continental subduction and exhumation of HP and UHP rocks: Gondwana Research, v. 25, no. 2, p. 464-493.

Carroll, A., Graham, S., Hendrix, M., Ying, D., and Zhou, D., 1995, Late Paleozoic tectonic amalgamation of northwestern China: sedimentary record of the northern Tarim, northwestern Turpan, and southern Junggar basins: Geological Society of America Bulletin, v. 107, no. 5, p. 571-594.

Carson, C., Powell, R., and Clarke, G., 1999, Calculated mineral equilibria for eclogites in $\mathrm{CaO}-\mathrm{Na} 2 \mathrm{O}-\mathrm{FeO}-\mathrm{MgO}-\mathrm{Al} 2 \mathrm{O} 3-\mathrm{SiO} 2-\mathrm{H} 2 \mathrm{O}$ : application to the Pouébo Terrane, Pam Peninsula, New Caledonia: Journal of Metamorphic Geology, v. 17, no. 1, p. 9-24.

Carswell, D. A., 1990, Eclogite facies rocks, Springer.

Chen, Y., Ye, K., Wu, T., and Guo, S., 2013, Exhumation of oceanic eclogites: thermodynamic constraints on pressure, temperature, bulk composition and density: Journal of Metamorphic Geology, v. 31, no. 5, p. 549-570.

Cocker, J., Griffin, B., and Muehlenbachs, K., 1982, Oxygen and carbon isotope evidence for seawater-hydrothermal alteration of the Macquarie Island ophiolite: Earth and Planetary Science Letters, v. 61, no. 1, p. 112-122.

Coggon, R., and Holland, T., 2002, Mixing properties of phengitic micas and revised garnet - phengite thermobarometers: Journal of Metamorphic Geology, v. 20, no. 7, p. 683-696.

Connolly, J., 1990, Multivariable phase diagrams; an algorithm based on generalized thermodynamics: American Journal of Science, v. 290, no. 6, p. 666-718.

-, 2005, Computation of phase equilibria by linear programming: a tool for geodynamic modeling and its application to subduction zone decarbonation: Earth and Planetary Science Letters, v. 236, no. 1, p. 524-541.

Connolly, J. A., and Trommsdorff, V., 1991, Petrogenetic grids for metacarbonate rocks: pressure-temperature phase-diagram projection for mixed-volatile systems: Contributions to Mineralogy and Petrology, v. 108, no. 1-2, p. 93-105.

Connolly, J. A. D., and Kerrick, D. M., 2002, Metamorphic controls on seismic velocity of subducted oceanic crust at 100-250 km depth: Earth \& Planetary Science Letters, v. 204, no. 1-2, p. 61-74.

Dachs, E., Geiger, C., and Benisek, A., The uncertainty of the standard entropy and its effect on petrological calculations, in Proceedings EGU General Assembly Conference Abstracts2012, Volume 14, p. 4439. 
de Jong, K., Wang, B., Faure, M., Shu, L., Cluzel, D., Charvet, J., Ruffet, G., and Chen, Y., 2009, New 40Ar/39Ar age constraints on the Late Palaeozoic tectonic evolution of the western Tianshan (Xinjiang, northwestern China), with emphasis on Permian fluid ingress: International Journal of Earth Sciences, v. 98, no. 6, p. 1239-1258.

Degeling, H., Eggins, S., and Ellis, D., 2001, Zr budgets for metamorphic reactions, and the formation of zircon from garnet breakdown: Mineralogical Magazine, v. 65, no. 6, p. 749-758.

Diener, J. F. A., Powell, R., White, R. W., and Holland, T. J. B., 2007, A new thermodynamic model for clino- and orthoamphiboles in the system $\mathrm{Na} 2 \mathrm{O}-\mathrm{CaO}-\mathrm{FeO}-\mathrm{MgO}-\mathrm{Al} 2 \mathrm{O} 3-\mathrm{SiO} 2-\mathrm{H} 2 \mathrm{O}-\mathrm{O}$ : Journal of Metamorphic Geology, v. 25, no. 6, p. 631-656.

Du, J., Zhang, L., Lü, Z., and Chu, X., 2011, Lawsonite-bearing chloritoid-glaucophane schist from SW Tianshan, China: Phase equilibria and P-T path: Journal of Asian Earth Sciences, v. 42, no. 4, p. 684-693.

Du, J.-X., Zhang, L.-F., Shen, X.-J., and Bader, T., 2014, A new PTt path of eclogites from Chinese southwestern Tianshan: constraints from PT pseudosections and Sm-Nd isochron dating: Lithos, v. 200, p. 258-272.

Evans, T., 2004, A method for calculating effective bulk composition modification due to crystal fractionation in garnet - bearing schist: implications for isopleth thermobarometry: Journal of Metamorphic Geology, v. 22, no. 6, p. 547-557.

Federico, L., Capponi, G., Crispini, L., Scambelluri, M., and Villa, I., 2005, $39 \mathrm{Ar} / 40 \mathrm{Ar}$ dating of high-pressure rocks from the Ligurian Alps: Evidence for a continuous subduction-exhumation cycle: Earth and Planetary Science Letters, v. 240, no. 3-4, p. 668-680.

Gao, J., He, G., Li, M., Xiao, X., Tang, Y., Wang, J., and Zhao, M., 1995, mineralogy, petrology, metamorphic PTDt trajectory and exhumation mechanism of blueschists, south Tianshan, northwestern China: Tectonophysics, v. 250, no. 1, p. 151-168.

Gao, J., and Klemd, R., 2000, Eclogite Occurrences in the Southern Tianshan High-Pressure Belt, Xinjiang, Western China: Gondwana Research, v. 3, no. 1, p. 33-38.

-, 2003, Formation of HP-LT rocks and their tectonic implications in the western Tianshan Orogen, NW China: geochemical and age constraints: Lithos, v. 66 , no. 1, p. 1-22.

Gao, J., Klemd, R., Qian, Q., Xi Zhang, J. L., Jiang, T., and Yang, Y., 2011, The collision between the Yili and Tarim blocks of the Southwestern Altaids: Geochemical and age constraints of a leucogranite dike crosscutting the HP-LT metamorphic belt in the Chinese Tianshan Orogen: Tectonophysics, v. 499, no. 1-4, p. 118-131. 
Gao, J., Klemd, R., Zhang, L., Wang, Z., and Xiao, X., 1999, PT path of high-pressure/low-temperature rocks and tectonic implications in the western Tianshan Mountains, NW China: Journal of Metamorphic Geology, v. 17, p. 621-636.

Gao, J., Long, L., Klemd, R., Qian, Q., Liu, D., Xiong, X., Su, W., Liu, W., Wang, Y., and Yang, F., 2009, Tectonic evolution of the South Tianshan orogen and adjacent regions, NW China: geochemical and age constraints of granitoid rocks: International Journal of Earth Sciences, v. 98, no. 6, p. 1221-1238.

Gao, J., Long, L., Qian, Q., Huang, D., Su, W., and KLEMD, R., 2006, South Tianshan: Late Paleozoic or Triassic collision orogenic belt?: Acta Petrologica Sinica (in Chinese), v. 22, no. 5, p. 1049-1061.

Gao, J., Maosong, L., Xuchang, X., Yaoqing, T., and Guoqi, H., 1998, Paleozoic tectonic evolution of the Tianshan Orogen, northwestern China: Tectonophysics, v. 287, no. 1, p. 213-231.

Gao, J., and Zhang, L., 2000, The formation of blueschist and eclogite in West tianshan mountains, China and its uplift history insight from the $\mathrm{Ar} / \mathrm{Ar}$ ages: Chinese Science Bulletin, v. 45, no. 1, p. 89-94.

Gerya, T. V., Stöckhert, B., and Perchuk, A. L., 2002, Exhumation of high pressure metamorphic rocks in a subduction channel: $A$ numerical simulation: Tectonics, v. 21, no. 6, p. 6-1-6-19.

Green, E., Holland, T., and Powell, R., 2007, An order-disorder model for omphacitic pyroxenes in the system jadeite-diopsidehedenbergite-acmite, with applications to eclogitic rocks: American Mineralogist, v. 92, no. 7, p. 1181-1189.

Guillot, S., Hattori, K., Agard, P., Schwartz, S., and Vidal, O., 2009, Exhumation processes in oceanic and continental subduction contexts: a review, Subduction zone geodynamics, Springer, p. 175-205.

Guillot, S., Schwartz, S., Reynard, B., Agard, P., and Prigent, C., 2015, Tectonic significance of serpentinites: Tectonophysics, v. 646, p. 1-19.

Hawthorne, F. C., and Oberti, R., 2006, On the classification of amphiboles: The Canadian Mineralogist, v. 44, no. 1, p. 1-21.

Hegner, E., Klemd, R., Kröner, A., Corsini, M., Alexeiev, D., laccheri, L., Zack, T., Dulski, P., Xia, X., and Windley, B., 2010, Mineral ages and PT conditions of Late Paleozoic high-pressure eclogite and provenance of mélange sediments from Atbashi in the south Tianshan orogen of Kyrgyzstan: American Journal of Science, v. 310, no. 9, p. 916-950.

Holland, T., and Powell, R., 1998, An internally consistent thermodynamic data set for phases of petrological interest: Journal of metamorphic Geology, v. 16 , no. 3 , p. 309-343.

Holland, T., and Powell, R., 2003, Activity-composition relations for phases in petrological calculations: an asymmetric multicomponent formulation: 
Contributions to Mineralogy and Petrology, v. 145, no. 4, p. 492-501.

Holland, T. J. B., and Powell, R., 2011, An improved and extended internally consistent thermodynamic dataset for phases of petrological interest, involving a new equation of state for solids: Journal of Metamorphic Geology, v. 29, no. 3, p. 333-383.

John, T., Gussone, N., Podladchikov, Y. Y., Bebout, G. E., Dohmen, R., Halama, R., Klemd, R., Magna, T., and Seitz, H.-M., 2012, Volcanic arcs fed by rapid pulsed fluid flow through subducting slabs: Nature Geoscience, v. 5, no. 7, p. 489-492.

John, T., Klemd, R., Gao, J., and Garbe-Schönberg, C.-D., 2008, Trace-element mobilization in slabs due to non steady-state fluid-rock interaction: constraints from an eclogite-facies transport vein in blueschist (Tianshan, China): Lithos, v. 103, no. 1, p. 1-24.

John, T., Scherer, E. E., Haase, K., and Schenk, V., 2004, Trace element fractionation during fluid-induced eclogitization in a subducting slab: trace element and $\mathrm{Lu}-\mathrm{Hf}-\mathrm{Sm}-\mathrm{Nd}$ isotope systematics: Earth and Planetary Science Letters, v. 227, no. 3-4, p. 441-456.

Kelley, K. A., Plank, T., Ludden, J., and Staudigel, H., 2003, Composition of altered oceanic crust at ODP Sites 801 and 1149: Geochemistry, Geophysics, Geosystems, v. 4, no. 6, p. 8910.

Klemd, R., Bröcker, M., Hacker, B., Gao, J., Gans, P., and Wemmer, K., 2005, New age constraints on the metamorphic evolution of the high pressure/low - temperature belt in the western Tianshan Mountains, NW China: The Journal of Geology, v. 113, no. 2, p. 157-168.

Klemd, R., Gao, J., Li, J.-L., and Meyer, M., 2014, Metamorphic evolution of (ultra)-high-pressure subduction-related transient crust in the South Tianshan Orogen (Central Asian Orogenic Belt): Geodynamic implications: Gondwana Research, v. 28, no. 1, p. 1-25.

Klemd, R., John, T., Scherer, E., E, Rondenay, S., and Gao, J., 2011, Changes in dip of subducted slabs at depth: Petrological and geochronological evidence from HP-UHP rocks (Tianshan, NW-China): EPSL, v. 310, no. 1, p. 9-20.

Klemd, R., Schroter, F., Will, T., and Gao, J., 2002, P-T evolution of glaucophane-omphacite bearing HP-LT rocks in the western Tianshan Orogen, NW China:new evidence for 'Alpine - type' tectonics: Journal of Metamorphic Geology, v. 20, no. 2, p. 239-254.

Kohn, M. J., Corrie, S. L., and Markley, C., 2015, The fall and rise of metamorphic zircon: American Mineralogist, v. 100, no. 4, p. 897-908.

Konrad-Schmolke, M., Zack, T., O'Brien, P. J., and Jacob, D. E., 2008, Combined thermodynamic and rare earth element modelling of garnet growth during subduction: Examples from ultrahigh-pressure eclogite of the Western Gneiss Region, Norway: Earth and Planetary Science 
Letters, v. 272, no. 1-2, p. 488-498.

Laurent - Charvet, S., Charvet, J., Monie, P., and Shu, L., 2003, Late Paleozoic strike - slip shear zones in eastern Central Asia (NW China): New structural and geochronological data: Tectonics, v. 22, no. 2, p. 237-241. Leake, B. E., 1978, Nomenclature of amphiboles: The Canadian Mineralogist, v. 16 , no. 4 , p. 501-520.

LePu, X., Song, S., Zhang, L., and Wei, C., 2011, Silurian arc volcanic slices and their tectonic implications in the southwestern Tianshan UHPM belt, NW China: Acta Petrologica Sinica, v. 27, no. 6, p. 1675-1687.

Li, J.-L., Klemd, R., Gao, J., Jiang, T., and Song, Y.-H., 2015, A common high-pressure metamorphic evolution of interlayered eclogites and metasediments from the 'ultrahigh-pressure unit'of the Tianshan metamorphic belt in China: Lithos, v. 226, p. 169-182.

Li, J.-L., Klemd, R., Gao, J., and John, T., 2016, Poly-cyclic Metamorphic Evolution of Eclogite: Evidence for Multistage Burial-Exhumation Cycling in a Subduction Channel: Journal of Petrology, v. 57, no. 1, p. 119-146.

Li, J.-L., Klemd, R., Gao, J., and Meyer, M., 2012, Coexisting carbonate-bearing eclogite and blueschist in SW Tianshan, China: petrology and phase equilibria: Journal of Asian Earth Sciences, v. 60, p. 174-187.

-, 2014, Compositional zoning in dolomite from lawsonite-bearing eclogite (SW Tianshan, China): Evidence for prograde metamorphism during subduction of oceanic crust: American Mineralogist, v. 99, no. 1, p. 206-217.

Li, Q.-L., Li, X.-H., Liu, Y., Tang, G.-Q., Yang, J.-H., and Zhu, W.-G., 2010a, Precise $\mathrm{U}-\mathrm{Pb}$ and $\mathrm{Pb}-\mathrm{Pb}$ dating of Phanerozoic baddeleyite by SIMS with oxygen flooding technique: Journal of Analytical Atomic Spectrometry, v. 25, no. 7, p. 1107-1113.

Li, Q.-I., Lin, W., Su, W., Li, X.-h., Shi, Y.-h., Liu, Y., and Tang, G.-q., 2011, SIMS $\mathrm{U}-\mathrm{Pb}$ rutile age of low-temperature eclogites from southwestern Chinese Tianshan, NW China: Lithos, v. 122, no. 1-2, p. 76-86.

Li, S., Jagoutz, E., Chen, Y., and Li, Q., 2000, Sm-Nd and Rb-Sr isotopic chronology and cooling history of ultrahigh pressure metamorphic rocks and their country rocks at Shuanghe in the Dabie Mountains, Central China: Geochimica et Cosmochimica Acta, v. 64, no. 6, p. 1077-1093.

Li, S., Wang, S., Chen, Y., Liu, D., Qiu, J., Zhou, H., and Zhang, Z., 1994, Excess argon in phengite from eclogite: Evidence from dating of eclogite minerals by Sm-Nd, Rb-Sr and 40Ar-39Ar methods: Chemical Geology, v. 112 , no. 3 , p. 343-350.

Li, X.-H., Li, W.-X., and Li, Q.-L., 2010b, Petrogenesis and tectonic significance of the $850 \mathrm{Ma}$ Gangbian alkaline complex in South China: evidence 
from in situ zircon $\mathrm{U}-\mathrm{Pb}$ dating, $\mathrm{Hf}-\mathrm{O}$ isotopes and whole-rock geochemistry: Lithos, v. 114, no. 1, p. 1-15.

Li, X.-P., Zhang, L.-F., A, W. S., Biao, S., and Liu, X.-M., 2010c, Zircons from rodingite in the Western Tianshan serpentinite complex: Mineral chemistry and $\mathrm{U}-\mathrm{Pb}$ ages define nature and timing of rodingitization: Lithos, v. 118, no. 1-2, p. 17-34.

Li, X. H., Liu, Y., Li, Q. L., Guo, C. H., and Chamberlain, K. R., 2009, Precise determination of Phanerozoic zircon $\mathrm{Pb} / \mathrm{Pb}$ age by multicollector SIMS without external standardization: Geochemistry, Geophysics, Geosystems, v. 10, no. 4, p. 573-575.

Li, X. H., Long, W. G., Li, Q. L., Liu, Y., Zheng, Y. F., Yang, Y. H., Chamberlain, K. R., Wan, D. F., Guo, C. H., and Wang, X. C., 2010d, Penglai zircon megacrysts: a potential new working reference material for microbeam determination of $\mathrm{Hf}-\mathrm{O}$ isotopes and $\mathrm{U}-\mathrm{Pb}$ age: Geostandards and Geoanalytical Research, v. 34, no. 2, p. 117-134.

Lifshin, E., and Gauvin, R., 2001, Minimizing errors in electron microprobe analysis: Microscopy and Microanalysis, v. 7, no. 02, p. 168-177.

Lin, W., and Enami, M., 2006, Prograde pressure-temperature path of jadeite-bearing eclogites and associated high-pressure/low-temperature rocks from western Tianshan, northwest China: Island Arc, v. 15, no. 4, p. 483-502.

Lin, W., Faure, M., Shi, Y., Wang, Q., and Li, Z., 2008, Palaeozoic tectonics of the south-western Chinese Tianshan: new insights from a structural study of the high-pressure/low-temperature metamorphic belt: International Journal of Earth Sciences, v. 98, no. 6, p. 1259-1274.

Liu, X., Su, W., Gao, J., Li, J., Jiang, T., Zhang, X., and Ge, X., 2014a, Paleozoic subduction erosion involving accretionary wedge sediments in the South Tianshan Orogen: Evidence from geochronological and geochemical studies on eclogites and their host metasediments: Lithos, v. 210-211, p. 89-110.

Liu, X.-C., Wu, Y.-B., Gao, S., Wang, H., Zheng, J.-P., Hu, Z.-C., Zhou, L., and Yang, S.-H., 2014b, Record of multiple stage channelized fluid and melt activities in deeply subducted slab from zircon $\mathrm{U}-\mathrm{Pb}$ age and $\mathrm{Hf}-\mathrm{O}$ isotope compositions: Geochimica et Cosmochimica Acta, v. 144, p. 1-24.

Lü, Z., and Zhang, L., 2012, Coesite in the eclogite and schist of the Atantayi Valley, southwestern Tianshan, China: Chinese Science Bulletin, v. 57, no. 13, p. 1467-1472.

Lü, Z., Zhang, L., Du, J., and Bucher, K., 2008, Coesite inclusions in garnet from eclogitic rocks in western Tianshan, northwest China: convincing proof of UHP metamorphism: American Mineralogist, v. 93, no. 11-12, p. 1845-1850. 
-, 2009, Petrology of coesite-bearing eclogite from Habutengsu Valley, western Tianshan, NW China and its tectonometamorphic implication: Journal of Metamorphic Geology, v. 27, no. 9, p. 773-787.

Lü, Z., Zhang, L., Du, J., Yang, X., Tian, Z., and Xia, B., 2012, The Habutengsu metapelites and metagreywackes in western Tianshan, China: metamorphic evolution and tectonic implications: Journal of Metamorphic Geology, v. 30, no. 9, p. 907-926.

Lucassen, F., Dulski, P., Abart, R., Franz, G., Rhede, D., and Romer, R. L., 2010, Redistribution of HFSE elements during rutile replacement by titanite: Contributions to Mineralogy and Petrology, v. 160, no. 2, p. 279-295.

Martin, L., Duchêne, S., Deloule, E., and Vanderhaeghe, O., 2006, The isotopic composition of zircon and garnet: A record of the metamorphic history of Naxos, Greece: Lithos, v. 87, no. 3-4, p. 174-192.

Martin, L. A. J., Duchêne, S., Deloule, E., and Vanderhaeghe, O., 2008, Mobility of trace elements and oxygen in zircon during metamorphism: Consequences for geochemical tracing: Earth and Planetary Science Letters, v. 267, no. 1-2, p. 161-174.

Meyer, M., Klemd, R., John, T., Gao, J., and Menneken, M., 2016, An (in - ) coherent metamorphic evolution of high - pressure eclogites and their host rocks in the Chinese southwest Tianshan?: Journal of Metamorphic Geology, v. 34, no. 2, p. 121-146.

Miller, J., and Cartwright, I., 2000, Distinguishing between seafloor alteration and fluid flow during subduction using stable isotope geochemistry: examples from Tethyan ophiolites in the Western Alps: Journal of Metamorphic Geology, v. 18, no. 5, p. 467-482.

Morimoto, N., 1988, Nomenclature of pyroxenes: Mineralogy and Petrology, v. 39 , no. 1 , p. 55-76.

Pearce, J. A., 2008, Geochemical fingerprinting of oceanic basalts with applications to ophiolite classification and the search for Archean oceanic crust: Lithos, v. 100, no. 1-4, p. 14-48.

Qian, Q., Gao, J., Xiong, X., Long, L., and Huang, D., 2006, Petrogenesis and tectonic settings of Carboniferous volcanic rocks from north Zhaosu, western Tianshan Mountains: constraints from petrology and geochemistry: Acta Petrol Sin, v. 22, no. 5, p. 1307-1323.

Rubatto, D., 2002, Zircon trace element geochemistry: partitioning with garnet and the link between $\mathrm{U}-\mathrm{Pb}$ ages and metamorphism: Chemical Geology, v. 184 , no. 1 , p. $123-138$.

Rubatto, D., and Angiboust, S., 2015, Oxygen isotope record of oceanic and high-pressure metasomatism: a P-T-time-fluid path for the Monviso eclogites (Italy): Contributions to Mineralogy and Petrology, v. 170, no. 5-6. 
Rubatto, D., and Hermann, J., 2003, Zircon formation during fluid circulation in eclogites (Monviso, Western Alps): implications for $\mathrm{Zr}$ and $\mathrm{Hf}$ budget in subduction zones: Geochimica et Cosmochimica Acta, v. 67, no. 12, p. 2173-2187.

Rudnick, R., and Gao, S., 2003, Composition of the continental crust: Treatise on geochemistry, v. 3, p. 1-64.

Ruffet, G., Gruau, G., Ballèvre, M., Féraud, G., and Philippot, P., 1997, Rb-Sr and 40Ar-39Ar laser probe dating of high-pressure phengites from the Sesia zone (Western Alps): underscoring of excess argon and new age constraints on the high-pressure metamorphism: Chemical Geology, v. 141 , no. 1 , p. 1-18.

Shen, T., Hermann, J., Zhang, L., Lü, Z., Padrón-Navarta, J. A., Xia, B., and Bader, T., 2015, UHP Metamorphism Documented in Ti-chondroditeand Ti-clinohumite-bearing Serpentinized Ultramafic Rocks from Chinese Southwestern Tianshan: Journal of Petrology, v. 56, no. 7, p. 1425-1458.

Sneeringer, M., Hart, S. R., and Shimizu, N., 1984, Strontium and samarium diffusion in diopside: Geochimica et Cosmochimica Acta, v. 48, no. 8, p. 1589-1608.

Soldner, J., Oliot, E., Schulmann, K., Štípská, P., Kusbach, V., and Anczkiewicz, R., 2016, Metamorphic P-T-t-d evolution of (U)HP metabasites from the South Tianshan accretionary complex (NW China) - Implications for rock deformation during exhumation in a subduction channel: Gondwana Research, v. in press.

Sorensen, S. S., Grossman, J. N., and Perfit, M. R., 1997, Phengite-hosted LILE enrichment in eclogite and related rocks: implications for fluid-mediated mass transfer in subduction zones and arc magma genesis: Journal of Petrology, v. 38, no. 1, p. 3-34.

Stacey, J. t., and Kramers, J., 1975, Approximation of terrestrial lead isotope evolution by a two-stage model: Earth and Planetary Science Letters, v. 26, no. 2, p. 207-221.

Su, W., Gao, J., Klemd, R., Li, J.-L., Zhang, X., Li, X.-H., Chen, N.-S., and Zhang, L., 2010, U-Pb zircon geochronology of Tianshan eclogites in NW China: implication for the collision between the Yili and Tarim blocks of the southwestern Altaids: European Journal of Mineralogy, v. 22, no. 4, p. 473-478.

Sun, S. s., and McDonough, W. F., 1989, Chemical and isotopic systematics of oceanic basalts: implications for mantle composition and processes: Geological Society, London, Special Publications, v. 42, no. 1, p. 313-345.

Tang, G.-Q., Li, X.-H., Li, Q.-L., Liu, Y., Ling, X.-X., and Yin, Q.-Z., 2015, Deciphering the physical mechanism of the topography effect for oxygen 
isotope measurements using a Cameca IMS-1280 SIMS: J. Anal. At. Spectrom., v. 30, no. 4, p. 950-956.

Tian, Z., and Wei, C., 2013, Metamorphism of ultrahigh-pressure eclogites from the Kebuerte Valley, South Tianshan, NW China: phase equilibria and P-T path: Journal of Metamorphic Geology, v. 31, no. 3, p. 281-300.

Van Achterbergh, E., Ryan, C., and Griffin, W., GLITTER: On-line Interactive Data Reduction for the Laser Ablation Inductively Coupled Plasma Mass Spectrometry Microprobe, in Proceedings Ninth Annual VM Goldschmidt Conference1999, Volume 1, p. 7215.

van der Straaten, F., Ralf Halama, T. J., Volker Schenk, F. H., and Andersen, N., 2008, Blueschist-facies rehydration of eclogites (Tian Shan, NW-China): Implications for fluid-rock interaction in the subduction channel: Chemical Geology, v. 255, no. 1, p. 195-219.

-, 2012, Tracing the effects of high-pressure metasomatic fluids and seawater alteration in blueschist-facies overprinted eclogites: Implications for subduction channel processes: Chemical Geology, v. 292, p. 69-87.

Villa, I. M., 1998, Isotopic closure: Terra Nova-Oxford, v. 10, no. 1, p. 42-47.

Villa, I. M., and Puxeddu, M., 1994, Geochronology of the Larderello geothermal field: new data and the "closure temperature" issue: Contributions to Mineralogy and Petrology, v. 115, no. 4, p. 415-426.

Volkova, N., and Budanov, V., 1999, Geochemical discrimination of metabasalt rocks of the Fan-Karategin transitional blueschist/greenschist belt, South Tianshan, Tajikistan: seamount volcanism and accretionary tectonics: Lithos, v. 47, no. 3, p. 201-216.

Wang, B., Faure, M., Shu, L., de Jong, K., Charvet, J., Cluzel, D., Jahn, B. m., Chen, Y., and Ruffet, G., 2010, Structural and geochronological study of high - pressure metamorphic rocks in the Kekesu section (northwestern China): Implications for the late Paleozoic tectonics of the Southern Tianshan: The Journal of Geology, v. 118, no. 1, p. 59-77.

Warren, C., and Waters, D., 2006, Oxidized eclogites and garnet - blueschists from Oman: P-T path modelling in the NCFMASHO system: Journal of Metamorphic Geology, v. 24, no. 9, p. 783-802.

Warren, C. J., 2013, Exhumation of (ultra-)high-pressure terranes: concepts and mechanisms: Solid Earth, v. 4, no. 1, p. 75-92.

Warren, C. J., Beaumont, C., and Jamieson, R. A., 2008, Modelling tectonic styles and ultra-high pressure (UHP) rock exhumation during the transition from oceanic subduction to continental collision: Earth and Planetary Science Letters, v. 267, no. 1-2, p. 129-145.

Wei, C., Powell, R., and Zhang, L., 2003, Eclogites from the south Tianshan, NW China: petrological characteristic and calculated mineral equilibria in the Na2O-CaO-FeO-MgO-Al2O3-SiO2-H2O system: Journal of Metamorphic Geology, v. 21, no. 2, p. 163-179. 
Wei, C., Wang, W., Clarke, G. L., Zhang, L., and Song, S., 2009, Metamorphism of high/ultrahigh-pressure pelitic-felsic schist in the South Tianshan Orogen, NW China: phase equilibria and P-T path: Journal of Petrology, v. 50, no. 10, p. 1973-1991.

Wei, C. J., and Clarke, G. L., 2011, Calculated phase equilibria for MORB compositions: a reappraisal of the metamorphic evolution of lawsonite eclogite: Journal of Metamorphic Geology, v. 29, no. 9, p. 939-952.

Whitney, D. L., and Evans, B. W., 2010, Abbreviations for names of rock-forming minerals: American Mineralogist, v. 95, no. 1, p. 185-187.

Wiedenbeck, M., Alle, P., Corfu, F., Griffin, W., Meier, M., Oberli, F., Quadt, A. v., Roddick, J., and Spiegel, W., 1995, Three natural zircon standards for U - Th - Pb, Lu - Hf, trace element and REE analyses: Geostandards newsletter, v. 19, no. 1, p. 1-23.

Williams, I. S., 1998, U-Th-Pb geochronology by ion microprobe: Reviews in Economic Geology, v. 7, no. 1, p. 1-35.

Williams, M., and Jercinovic, M., The Assessment of Error in Electron Microprobe Trace Element Analysis, in Proceedings AGU Spring Meeting Abstracts2006, Volume 1, p. 08.

Worley, B., and Powell, R., 2000, High-precision relative thermobarometry: theory and a worked example: Journal of Metamorphic Geology, v. 18, no. 1, p. 91-102.

Xia, B., Zhang, L., and Bader, T., 2014, Zircon U-Pb ages and Hf isotopic analyses of migmatite from the 'paired metamorphic belt' in Chinese SW Tianshan: Constraints on partial melting associated with orogeny: Lithos, v. 192-195, p. 158-179.

Xia, B., Zhang, L., Bader, T., Shen, T., and Chen, N., 2015, Late Palaeozoic40Ar/39Ar ages of the HP-LT metamorphic rocks from the Kekesu Valley, Chinese southwestern Tianshan: new constraints on exhumation tectonics: International Geology Review, p. 1-16.

Xin, Y., Lifei, Z., Zuolin, T., and Thomas, B., 2013, Petrology and U-Pb zircon dating of coesite-bearing metapelite from the Kebuerte Valley, western Tianshan, China: Journal of Asian Earth Sciences, v. 70-71, p. 295-307.

Zhang, L., Ai, Y., Li, X., Rubatto, D., Song, B., Williams, S., Song, S., Ellis, D., and Liou, J. G., 2007, Triassic collision of western Tianshan orogenic belt, China: Evidence from SHRIMP U-Pb dating of zircon from HP/UHP eclogitic rocks: Lithos, v. 96, no. 1-2, p. 266-280.

Zheng, Y.-f., 1991, Calculation of oxygen isotope fractionation in metal oxides: Geochimica et Cosmochimica Acta, v. 55, no. 8, p. 2299-2307.

-, 1993, Calculation of oxygen isotope fractionation in anhydrous silicate minerals: Geochimica et Cosmochimica Acta, v. 57, p. 1079-1079.

Zheng, Y. F., Gao, T. S., Wu, Y. B., Gong, B., and Liu, X. M., 2007, Fluid flow during exhumation of deeply subducted continental crust: zircon $\mathrm{U}-\mathrm{Pb}$ 
age and O-isotope studies of a quartz vein within ultrahigh-pressure eclogite: Journal of Metamorphic Geology, v. 25, no. 2, p. 267-283. 


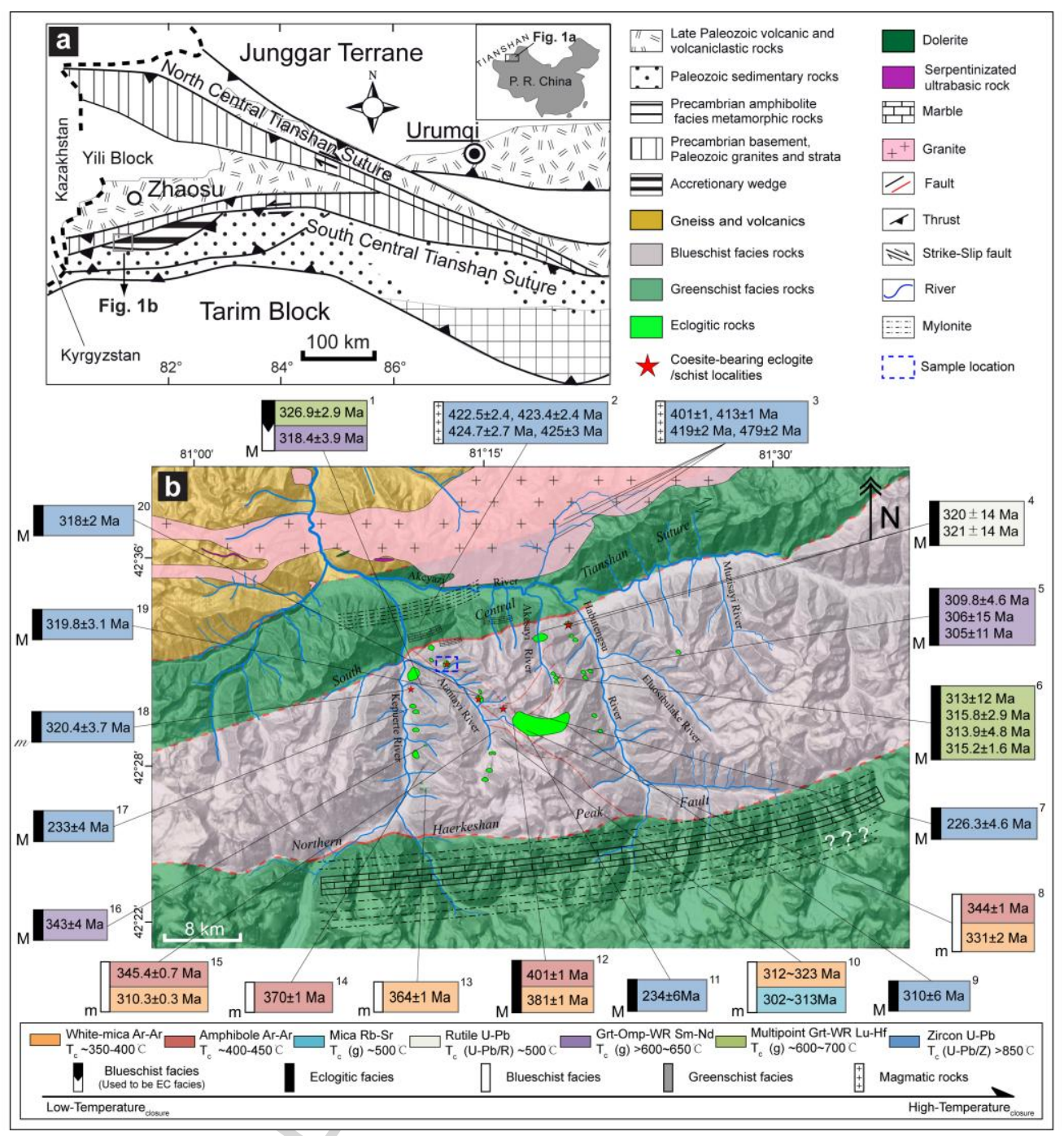

Figure 1 


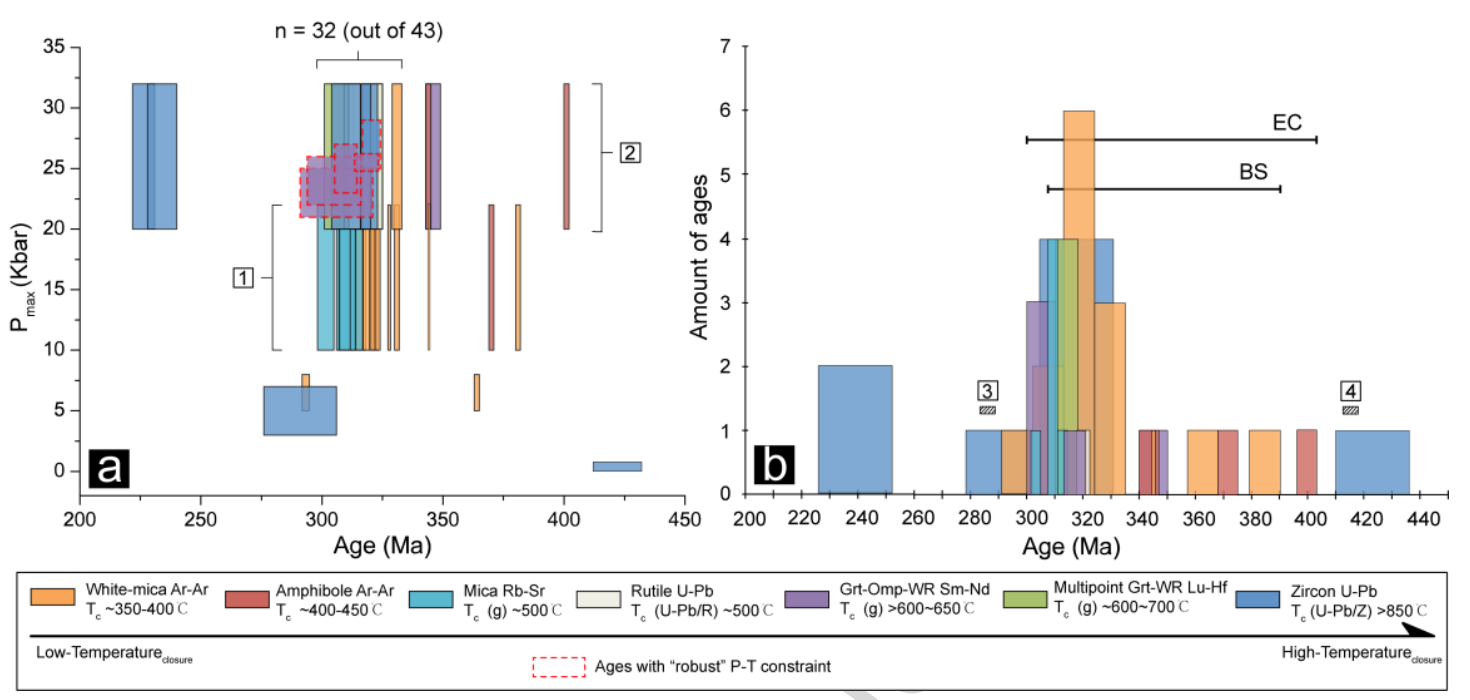

Figure 2 


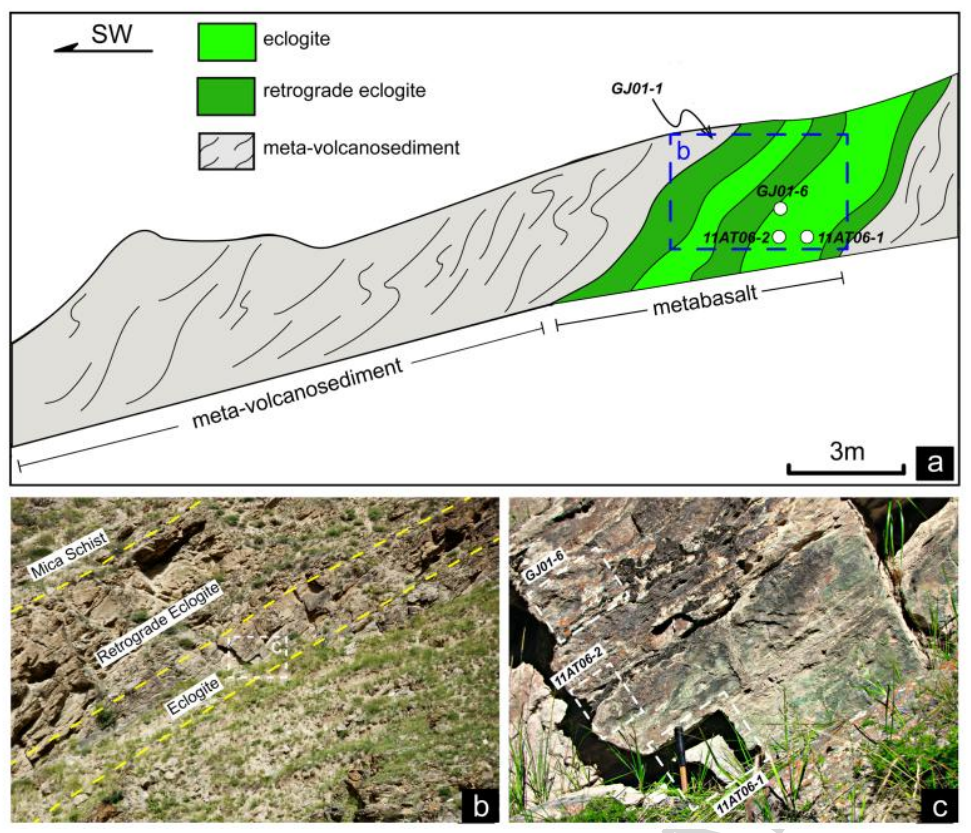

Figure 3 

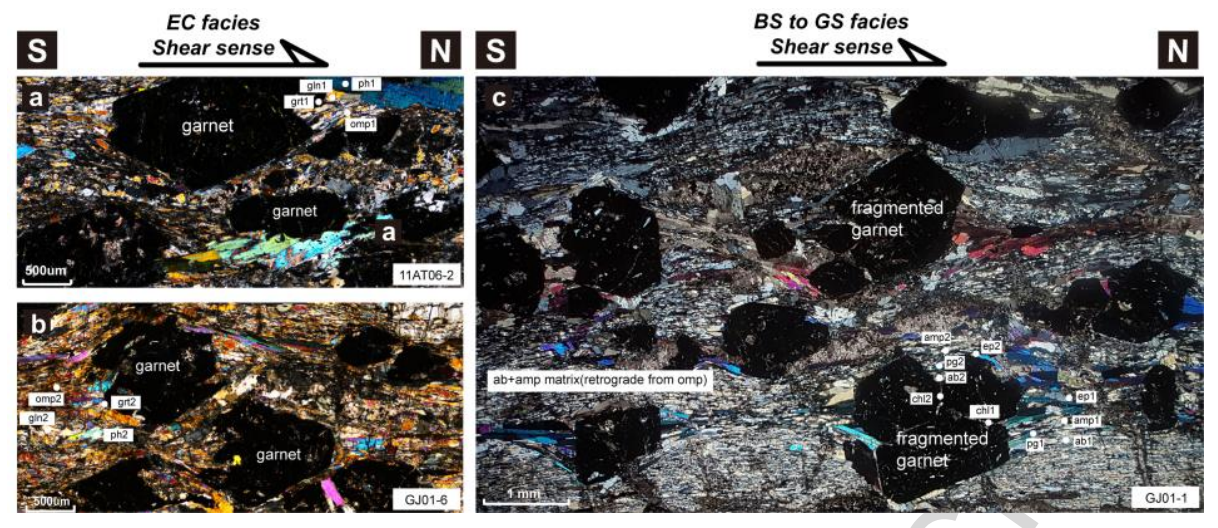

Figure 4 


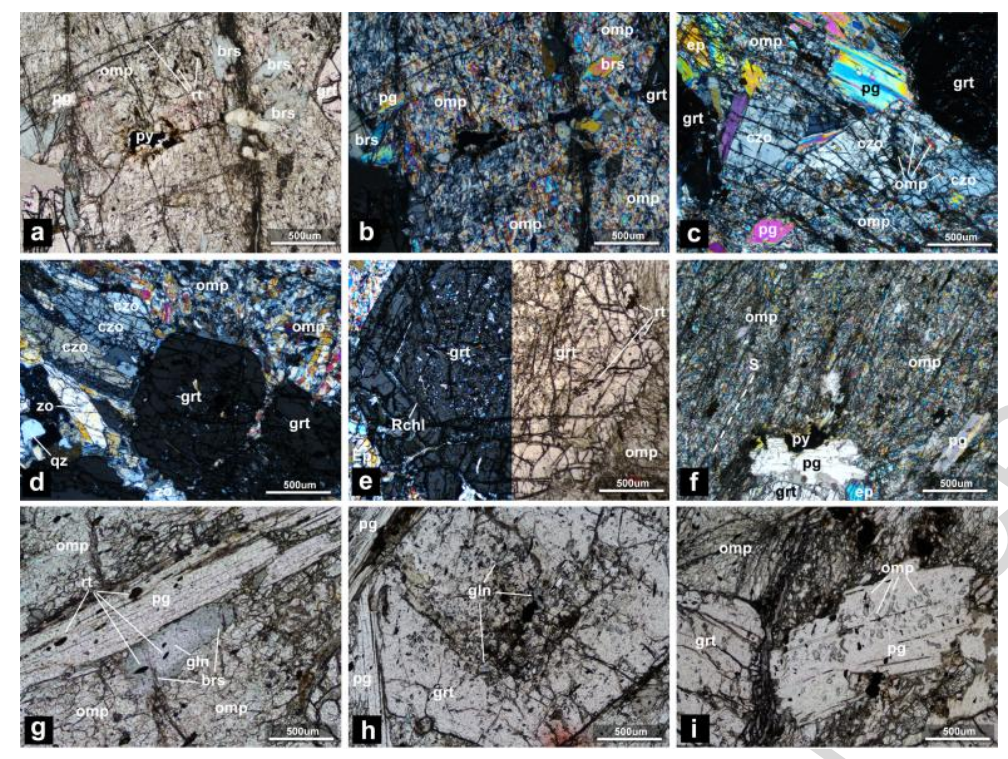

Figure 5 


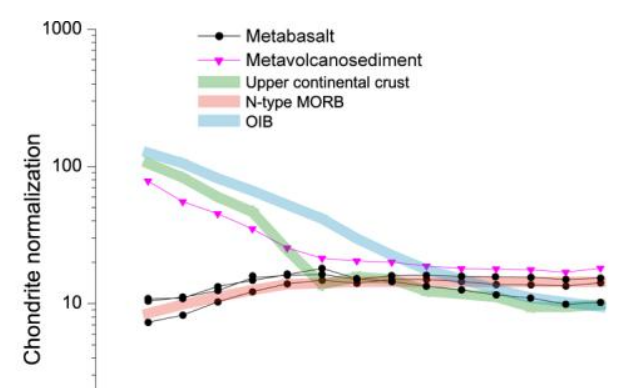

a
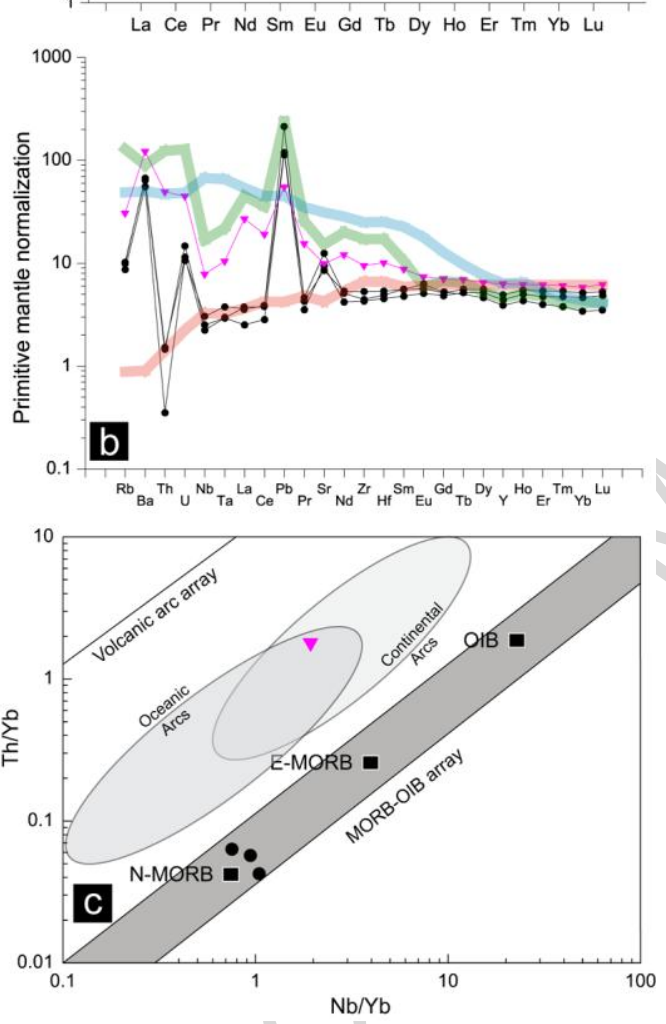

Figure 6 

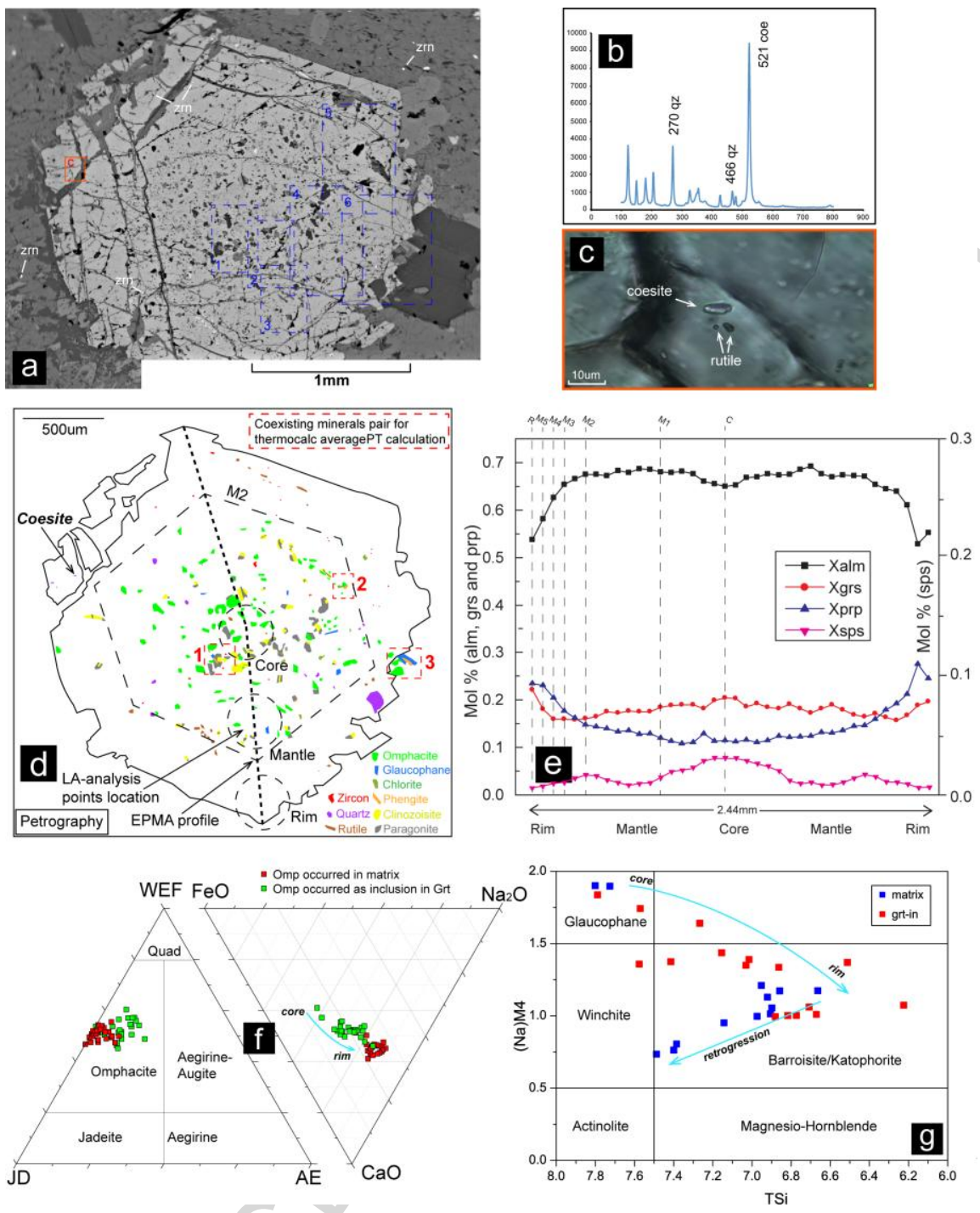

Figure 7 

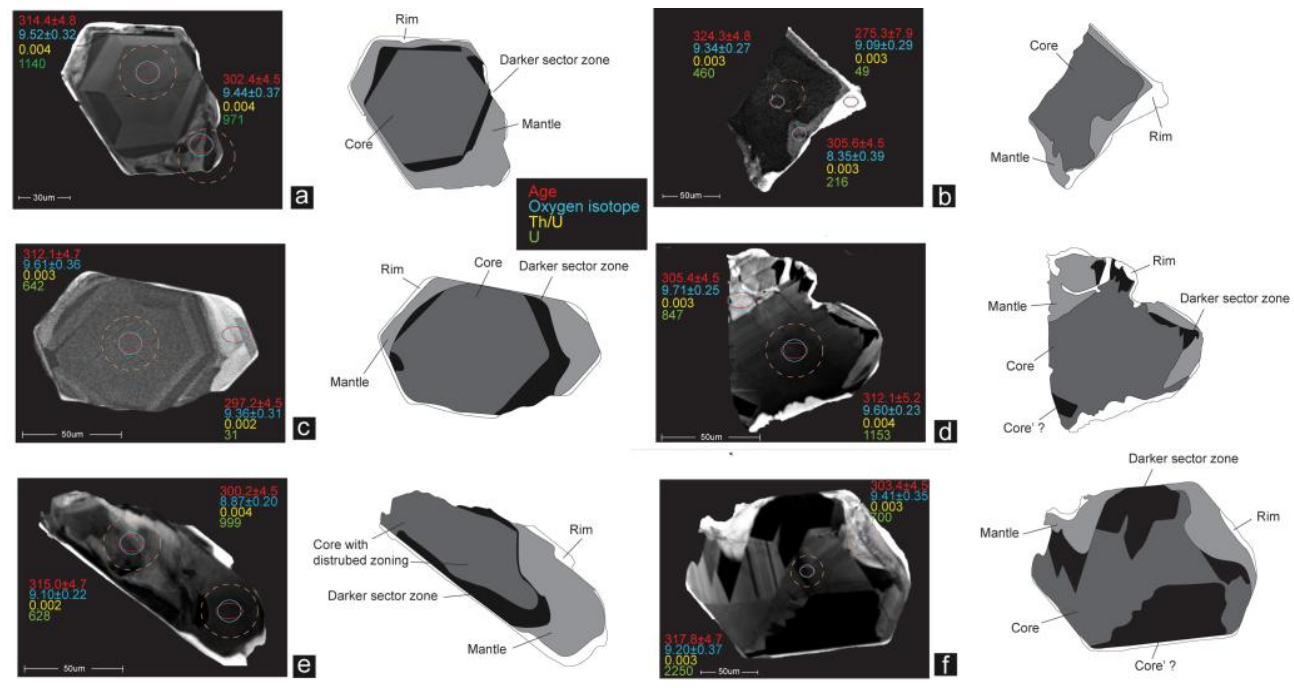

Figure 8 


\section{a zircon domains}
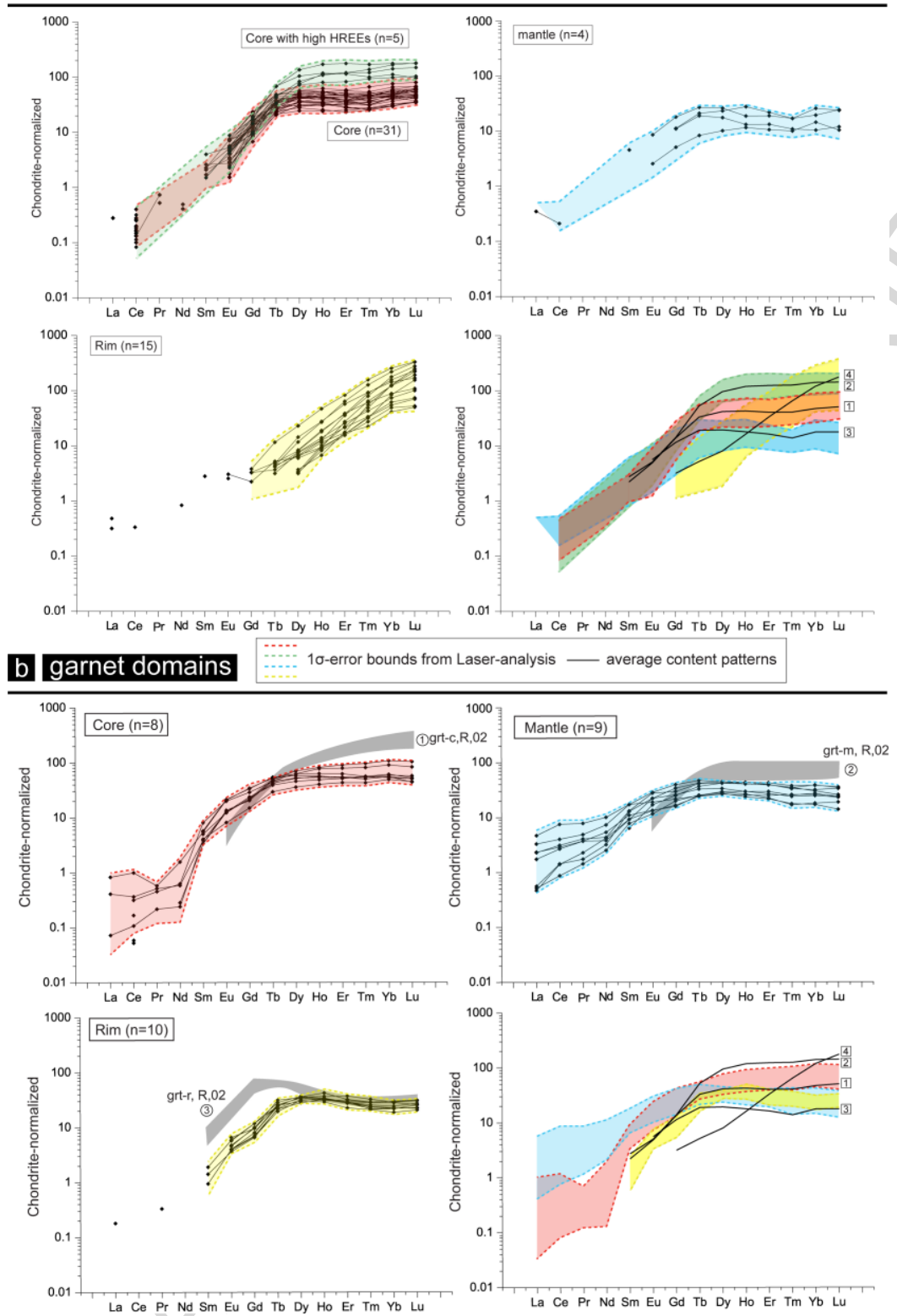

Figure 9 

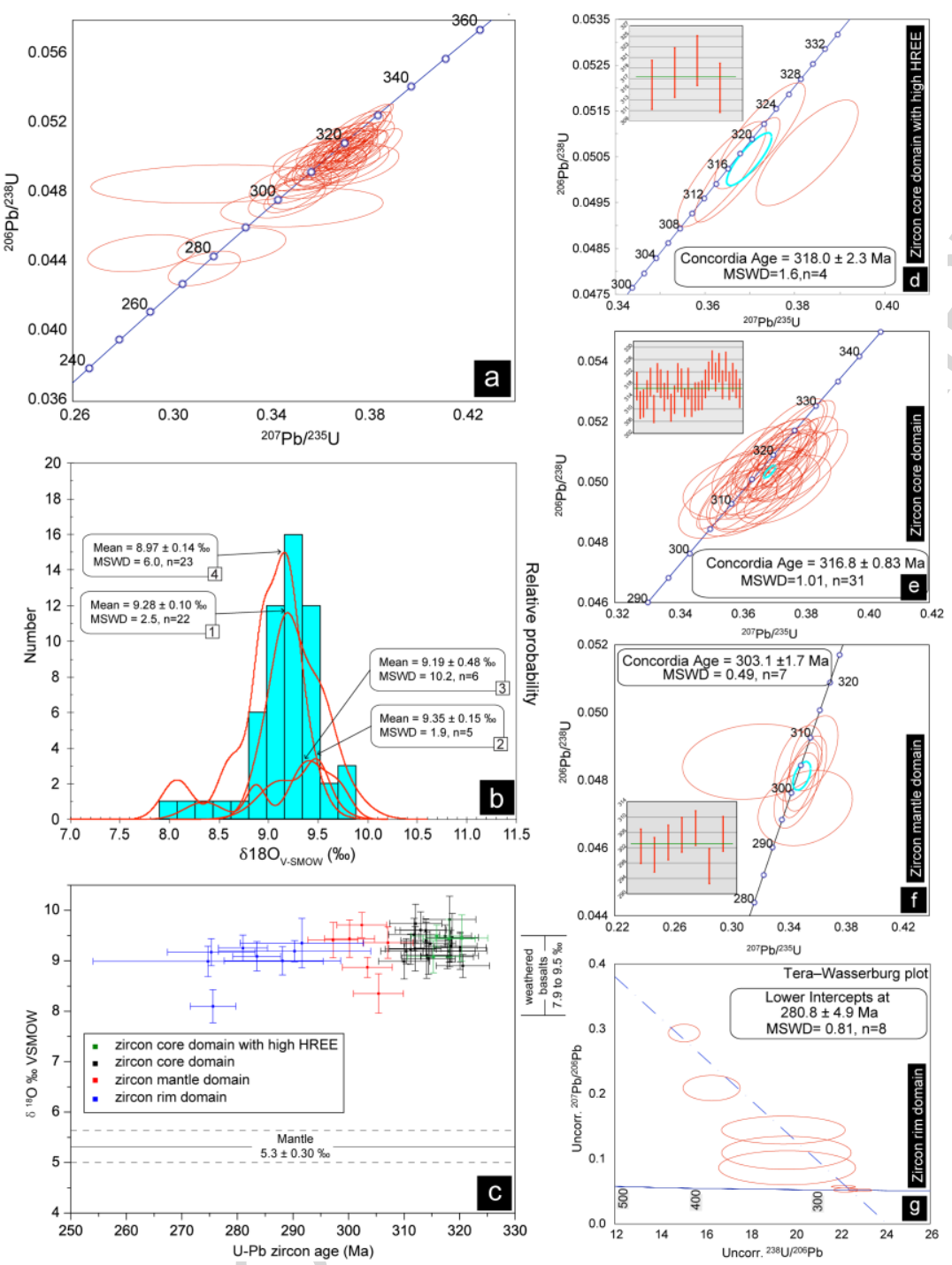

Figure 10 


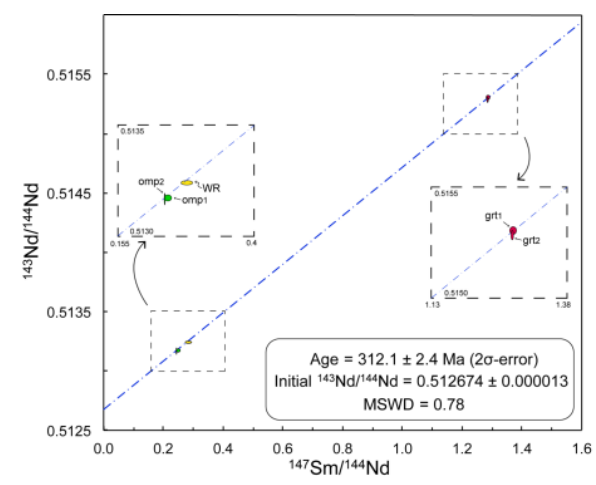

Figure 11 


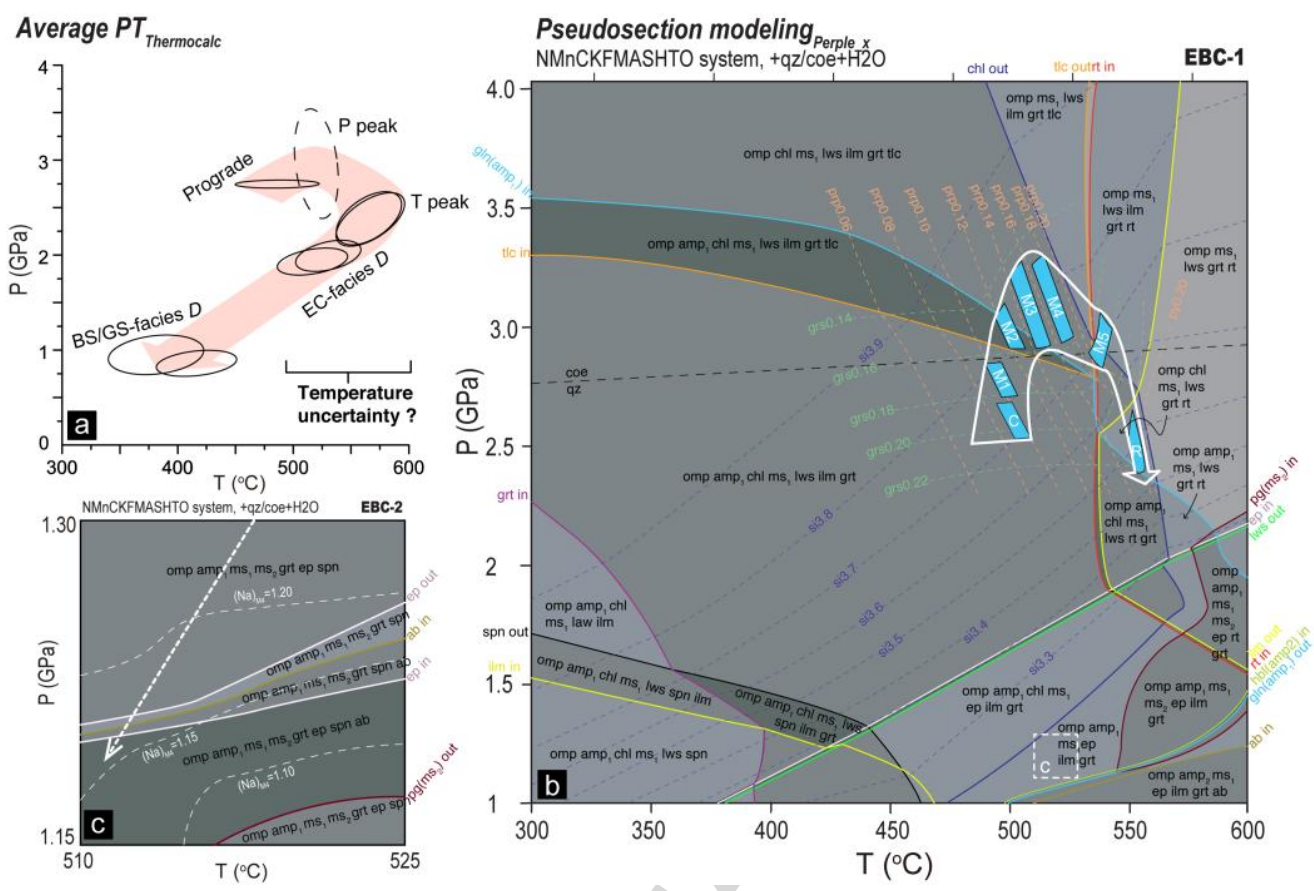

Figure 12 
a

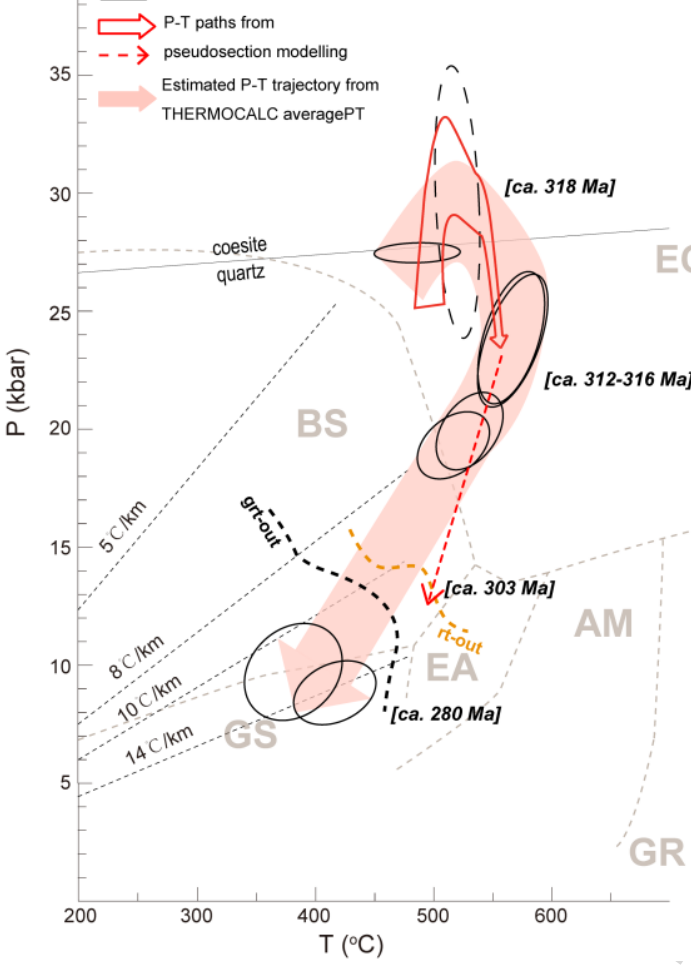

\section{b}

Eclogite/blueschist

- - - - Metasediment

$\longrightarrow$ Combined P-T trejectory

from this study Wei et al. 2009

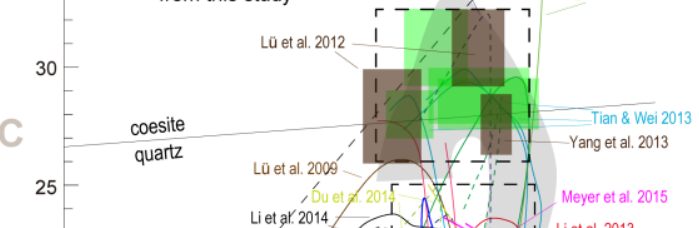

25 - Lü etal. 2009

20 - '

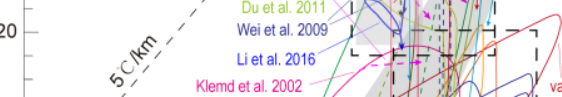

- ¿i, Klemd et al. 2002

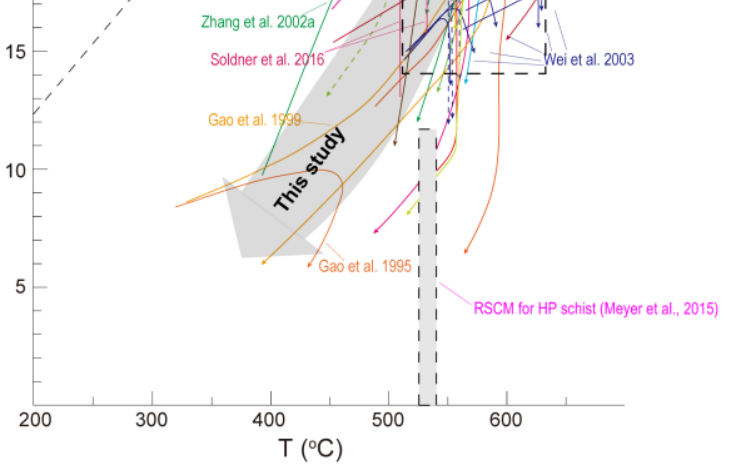

Figure 13 

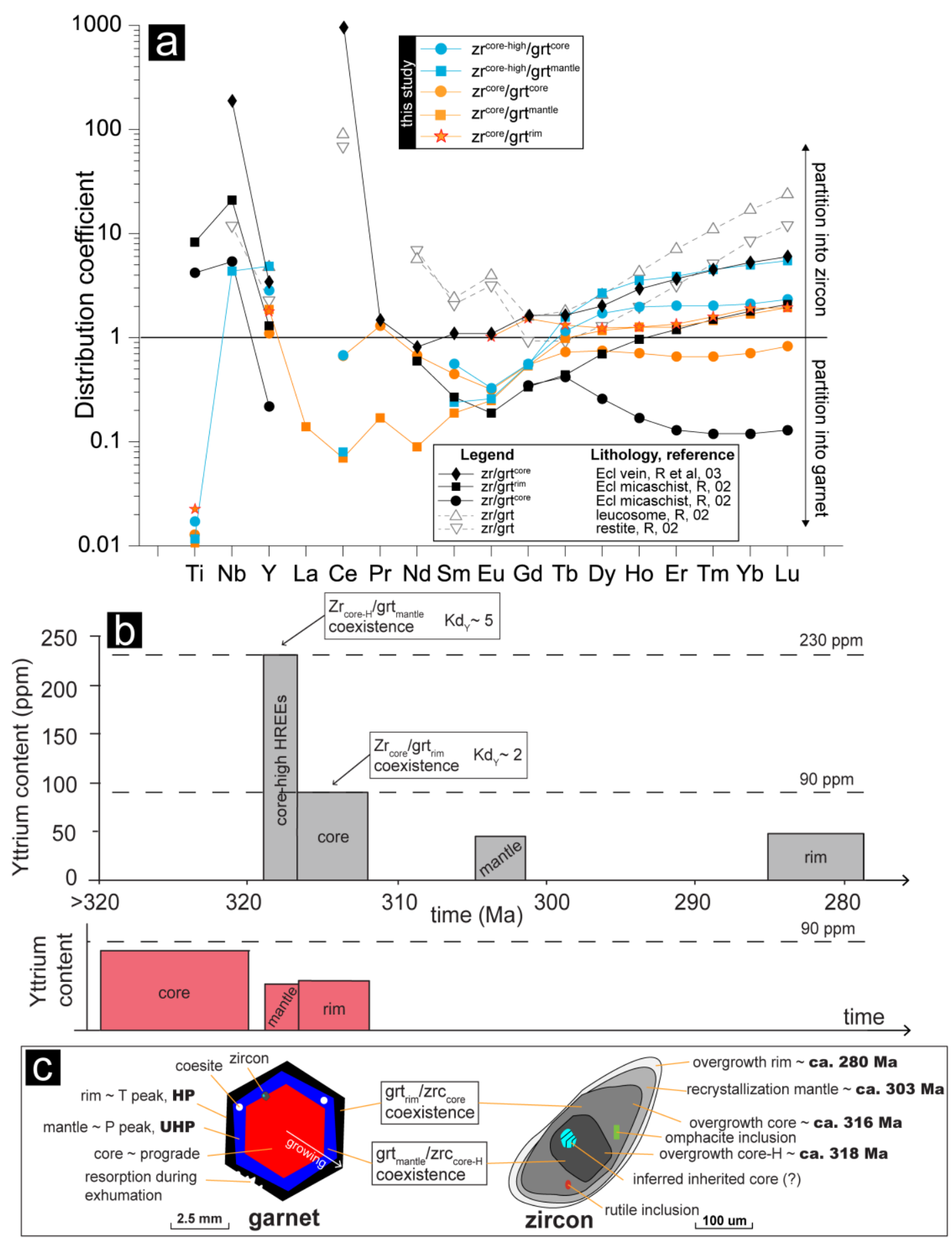

Figure 14 


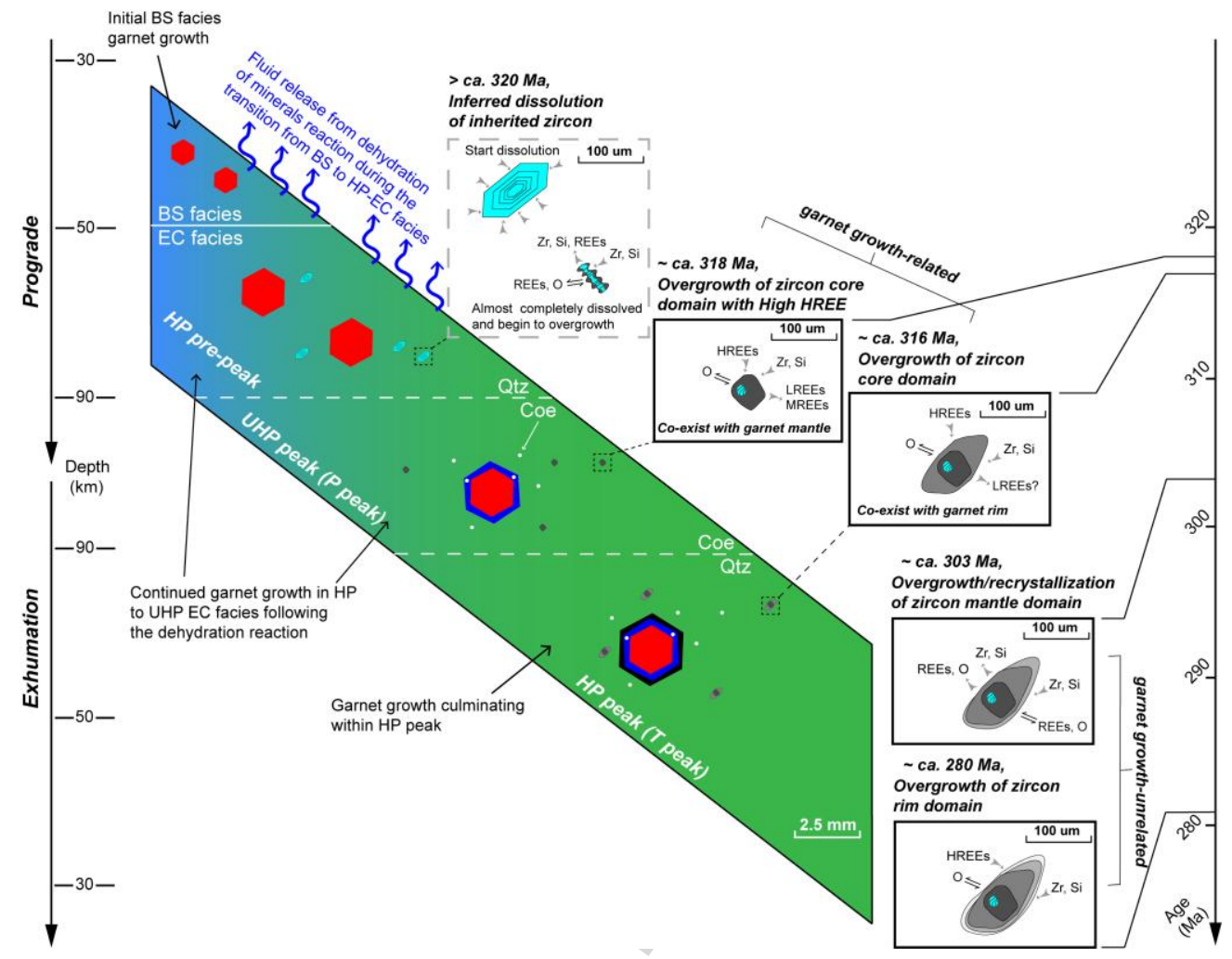

Figure 15 

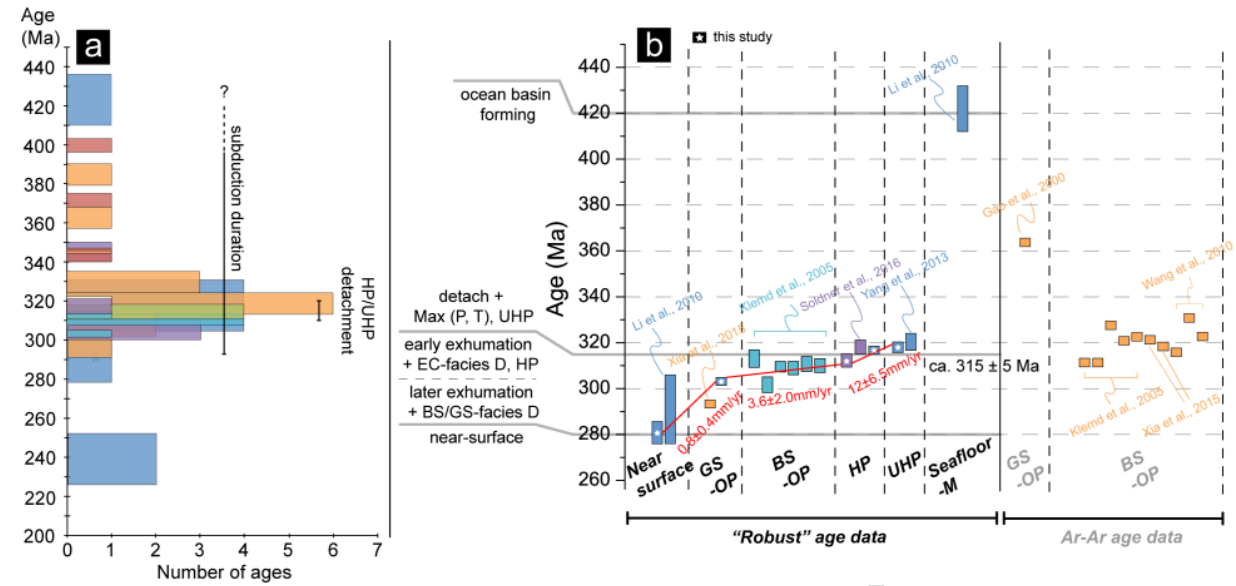

Figure 16 
ca. $318 \mathrm{Ma}$

Detachment + UHP metamorphism

S

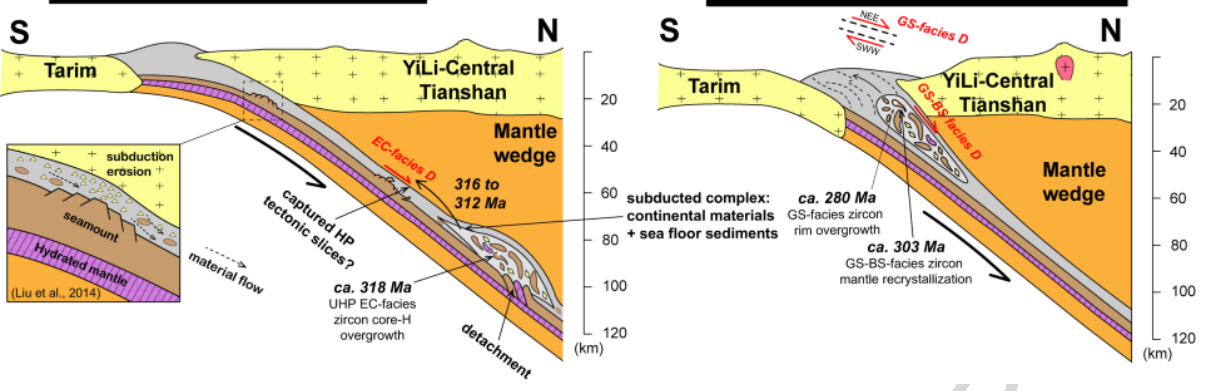

Figure 17 
Table 1

Modal abundances of mineral assemblage in vol.\%

\begin{tabular}{|c|c|c|c|c|c|c|c|c|c|c|c|c|}
\hline Samples & Grt & Omp & Amp & $\mathrm{Ph}$ & $\mathrm{Pg}$ & $\mathrm{Ep} / \mathrm{Zo}$ & Qz & Ap & Rt & Ttn & Lws & Fe-Ti oxide \\
\hline \multicolumn{13}{|l|}{ eclogite } \\
\hline 11AT06-1 & 18 & 58 & 5 & 0.5 & 5.5 & 8 & 1 & 1 & 1.5 & 0.5 & - & 1 \\
\hline 11AT06-2 & 19 & 55 & 7 & 1 & 4 & 6 & 3 & 2 & 1 & 1 & - & 1 \\
\hline GJ01-6 & 22 & 56 & 6 & 0.5 & 3.5 & 7 & 2 & 1 & 1 & 0.5 & - & 0.5 \\
\hline $\begin{array}{l}\text { Modeled abundances for Peak } \mathrm{T} \\
\text { condition (ca. } 550^{\circ} \mathrm{C}+2.5 \mathrm{GPa} \text { ) }\end{array}$ & 18.4 & 71 & - & 0.8 & & - & 1 & - & 0.9 & - & 7.4 & - \\
\hline \multicolumn{13}{|l|}{ Wall-rock mica schist } \\
\hline GJ01-1 & 20 & 29 & 2 & 5 & 15 & 1 & 22 & 5 & 0.5 & 0.5 & - & 0.1 \\
\hline
\end{tabular}

(hineral modes were determined from the thin section by point counting on the basis of petrographic observations. The uncertainty of modal abundances of minerals was estimated to be less than $10 \%$ by repeating the same operations. Modeled abundances of mineral assemblage for peak $T$ condition are calculated by pseudosection modeling with EBC-1. 
Table 2

\begin{tabular}{|c|c|c|c|c|c|c|}
\hline & \multicolumn{4}{|c|}{ XRF data } & \multirow{2}{*}{$\frac{\text { EBC-1 }}{\text { eclogite }}$} & \multirow{2}{*}{$\frac{\text { EBC-2 }}{\text { eclogite }}$} \\
\hline \multicolumn{2}{|l|}{ Lithology } & \multicolumn{2}{|l|}{ eclogite } & \multirow{2}{*}{$\frac{\text { Mica schist }}{\text { GJ01-1 }}$} & & \\
\hline Sample & 11AT06-1 & 11AT06-2 & GJ01-6 & & 11AT06-1 & 11AT06-1 \\
\hline \multicolumn{7}{|c|}{ Major elements (wt \%) } \\
\hline $\mathrm{SiO}_{2}$ & 47.97 & 47.62 & 46.92 & 54.33 & 50.63 & 52.47 \\
\hline $\mathrm{TiO}_{2}$ & 0.86 & 0.87 & 1.01 & 0.65 & 1.15 & 1.27 \\
\hline $\mathrm{Al}_{2} \mathrm{O}_{3}$ & 14.87 & 14.55 & 15.23 & 14.65 & 14.62 & 14.06 \\
\hline $\mathrm{MnO}$ & 0.23 & 0.14 & 0.14 & 0.14 & 0.10 & 0.05 \\
\hline $\mathrm{MgO}$ & 7.22 & 6.38 & 6.75 & 4.03 & 6.28 & 6.65 \\
\hline $\mathrm{CaO}$ & 10.05 & 11.75 & 10.69 & 7.18 & 11.53 & 12.15 \\
\hline $\mathrm{Na}_{2} \mathrm{O}$ & 4.15 & 4.60 & 5.10 & 3.96 & 5.31 & 5.92 \\
\hline $\mathrm{K}_{2} \mathrm{O}$ & 0.18 & 0.30 & 0.12 & 0.84 & 0.08 & 0.09 \\
\hline $\mathrm{P}_{2} \mathrm{O}_{5}$ & 0.42 & 0.08 & 0.20 & 0.14 & - & - \\
\hline Fetot $_{a}$ & 11.88 & 10.23 & 10.68 & 9.09 & - & - \\
\hline $\mathrm{FeO}$ & 8.72 & 7.28 & 7.80 & - & 8.23 & 5.87 \\
\hline $\mathrm{Fe}_{2} \mathrm{O}_{3}$ & 2.19 & 2.14 & 2.01 & - & 2.06 & 1.47 \\
\hline LOI & 1.86 & 3.34 & 2.68 & 4.86 & - & - \\
\hline Sum & 99.69 & 99.86 & 99.52 & 99.87 & 100.00 & 100.00 \\
\hline \multicolumn{7}{|c|}{ Trace elements (ug/g) } \\
\hline $\mathrm{Li}$ & 33.2 & 34.8 & 34.5 & 21.7 & & \\
\hline $\mathrm{Be}$ & 0.537 & 0.370 & 0.480 & 0.680 & & \\
\hline
\end{tabular}




$\begin{array}{lcccc}\mathrm{Sc} & 43.9 & 42.7 & 44.4 & 32.7 \\ \mathrm{~V} & 263 & 263 & 273 & 179 \\ \mathrm{Cr} & 290 & 299 & 320 & 104 \\ \mathrm{Co} & 43.8 & 39.7 & 34.4 & 25.0 \\ \mathrm{Ni} & 137 & 128 & 103 & 86.6 \\ \mathrm{Cu} & 86.7 & 103 & 62.1 & 105 \\ \mathrm{Zn} & 172 & 144 & 156 & 94 \\ \mathrm{Ga} & 14.8 & 14.9 & 16.6 & 19.1 \\ \mathrm{Rb} & 6.28 & 5.51 & 6.50 & 19.6 \\ \mathrm{Sr} & 180 & 200 & 263 & 209 \\ \mathrm{Y} & 22.5 & 20.1 & 17.8 & 28.6 \\ \mathrm{Zr} & 59.3 & 48.1 & 50.0 & 106 \\ \mathrm{Nb} & 2.17 & 1.60 & 1.79 & 5.57 \\ \mathrm{Cs} & 1.03 & 0.610 & 0.580 & 1.53 \\ \mathrm{Ba} & 10.0 & 386 & 454 & 853 \\ \mathrm{La} & 2.47 & 1.73 & 2.57 & 18.6 \\ \mathrm{Ce} & 6.81 & 5.05 & 6.69 & 33.9 \\ \mathrm{Pr} & 1.18 & 0.980 & 1.27 & 4.29 \\ \mathrm{Nd} & 7.20 & 5.69 & 6.90 & 16.4 \\ \mathrm{Sm} & 2.46 & 2.13 & 2.49 & 3.89 \\ \mathrm{Eu} & 0.949 & 0.860 & 1.05 & 1.24 \\ \mathrm{Gd} & 3.08 & 2.89 & 3.12 & 4.20 \\ \mathrm{~Tb} & 0.599 & 0.560 & 0.540 & 0.750 \\ \mathrm{Dy} & 4.08 & 3.81 & 3.40 & 4.78 \\ & & & & \end{array}$




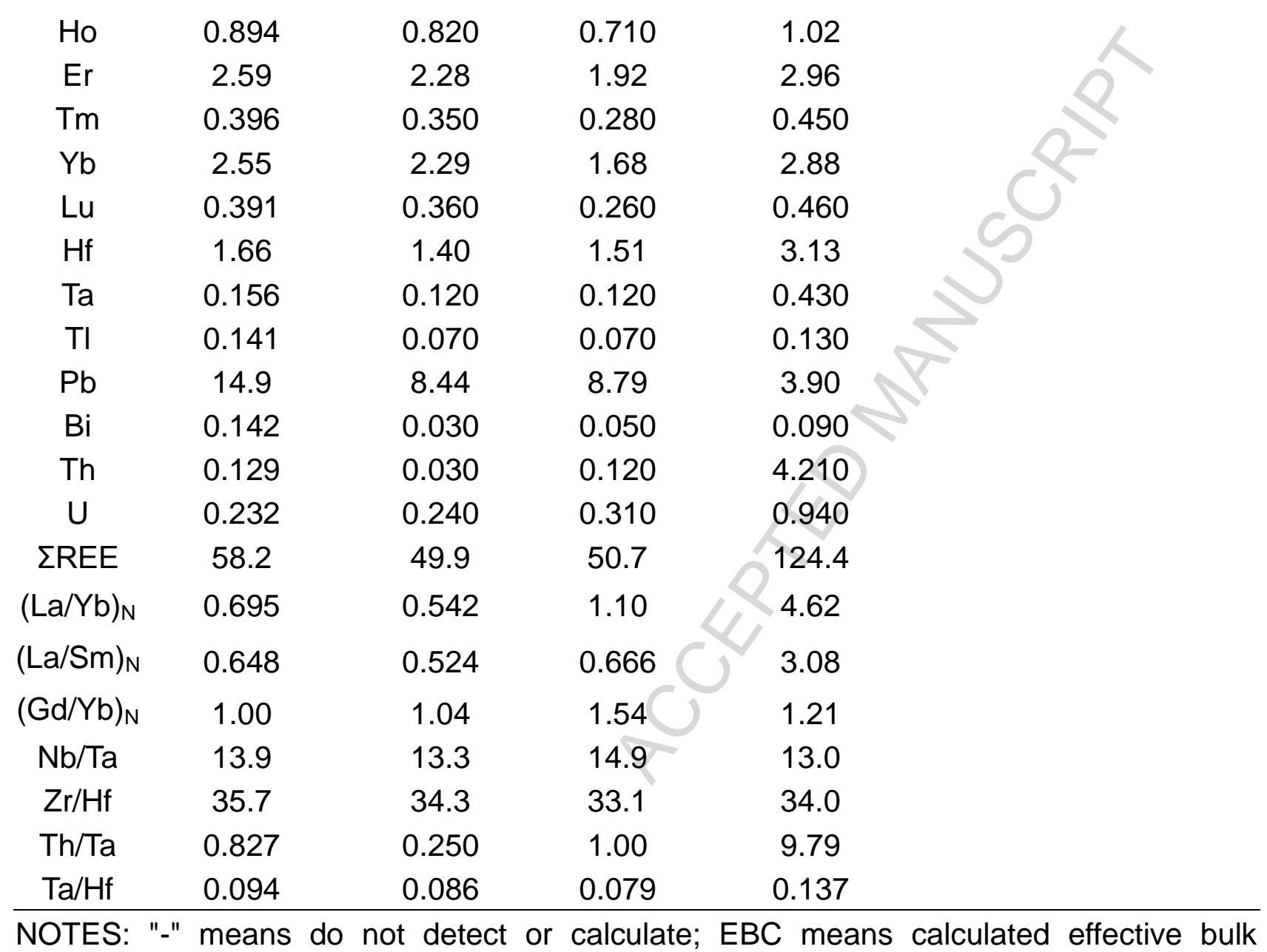


composition for pseudosection modeling; "Fetot $a$ " means the total amount of iron oxide analysed from XRF; The $\mathrm{Fe}_{2} \mathrm{O}_{3}$ content of bulk-rock is constrained from potassium permanganate titration method; The $\mathrm{Fe}_{2} \mathrm{O}_{3}$ and $\mathrm{FeO}$ contents of $\mathrm{EBCs}$ were calculated based on the constant ratio of $\mathrm{Fe}^{3+} / \mathrm{Fe}^{2+}$ from XRF data for evaluated composition; 
Table 3

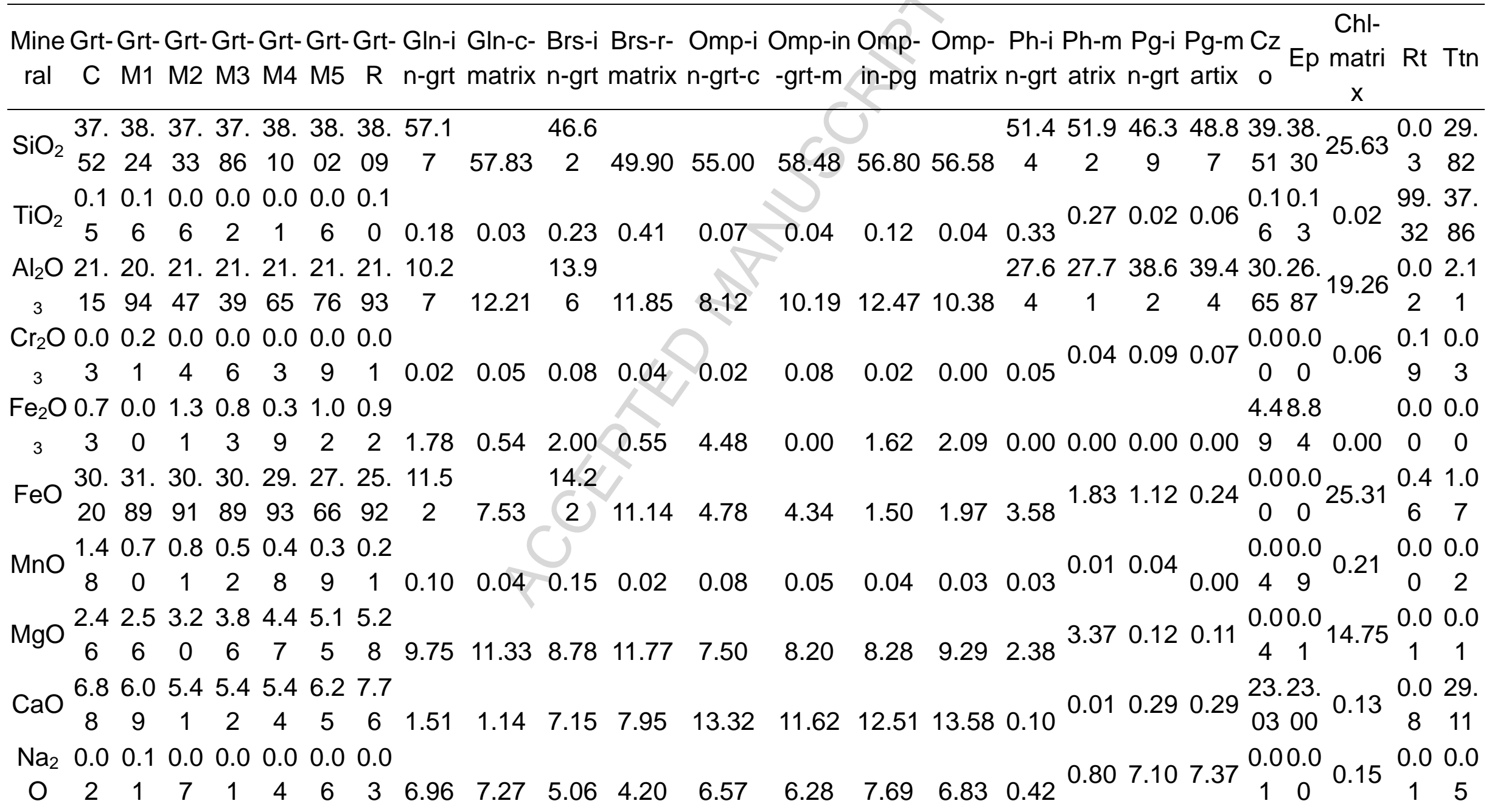


$\mathrm{K}_{2} \mathrm{O} \quad \begin{array}{llllllll}0.0 & 0.0 & 0.0 & 0.0 & 0.0 & 0.0 & 0.0\end{array}$

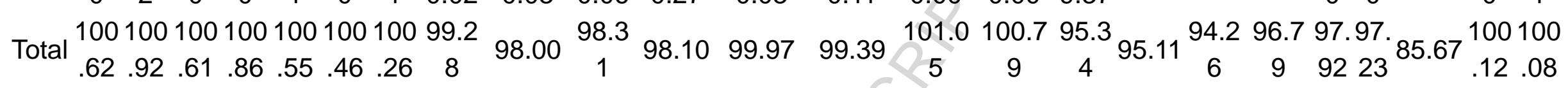

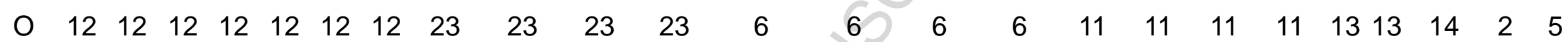

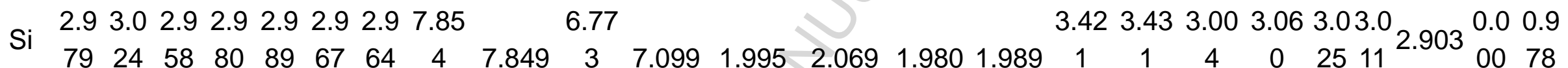

$\mathrm{Ti} \quad \begin{array}{llllllllllllllllll}0.0 & 0.0 & 0.0 & 0.0 & 0.0 & 0.0 & 0.0 & 0.01 & 0.02 & 0.01 & 0.01 & 0.00 & 0.00 & 0.00 .0 & 0.003 & 0.9 & 0.9\end{array}$

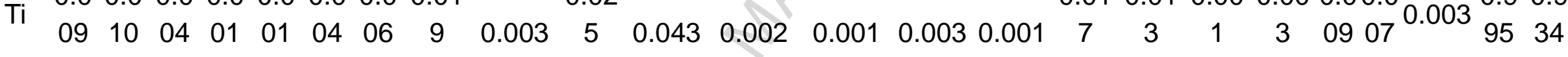

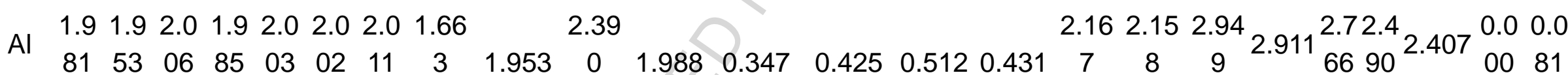

Cr $\begin{array}{llllllllllllllllllll}0.0 & 0.0 & 0.0 & 0.0 & 0.0 & 0.0 & 0.0 & 0.00 & 0.00 & 0.00 & 0.00 & 0.00 & 0.00 & 0.00 .0 & 0.010 & 0.0 & 0.0\end{array}$

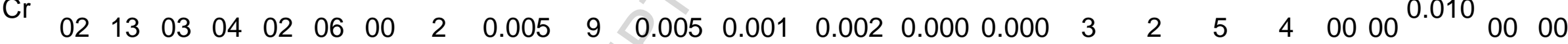

$\begin{array}{lllllllllllllllll}\mathrm{Fe}^{3+} & 0.0 & 0.0 & 0.0 & 0.0 & 0.0 & 0.0 & 0.0 & 0.18 & 0.21 & 0.00 & 0.00 & 0.00 & 0.00 & 0.20 .5 & 0.0 & 0.0\end{array}$

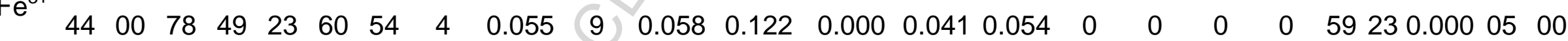
\begin{tabular}{c}
$\mathrm{Fe}^{2+}$ \\
\hline
\end{tabular} $\begin{array}{lllllllllllllllllllllllll}00 & 47 & 54 & 35 & 32 & 26 & 14 & 1 & 0.004 & 8 & 0.003 & 0.002 & 0.001 & 0.001 & 0.001 & 2 & 1 & 2 & 0 & 03 & 06 & 0.023 & 00 & 00\end{array}$

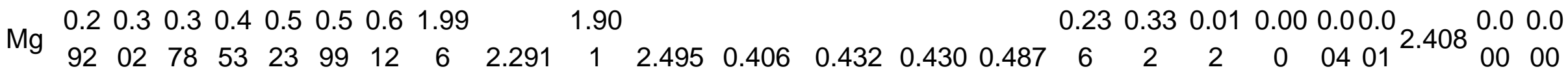

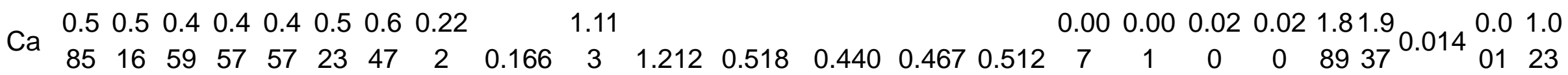




\begin{tabular}{|c|c|c|c|c|c|c|c|c|c|c|c|c|c|c|c|c|c|c|c|c|c|c|}
\hline & 03 & 17 & 11 & 02 & 06 & 09 & 04 & 3 & & 5 & & & & & & 4 & 2 & 2 & 4 & 0100 & 00 & 03 \\
\hline K & 0.0 & 0.0 & 0.0 & 0.0 & 0.0 & 0.0 & 0.0 & 0.00 & $0 \cap 05$ & 0.01 & 0049 & $\cap \cap \cap 1$ & $\cap \cap 0$ & & & 0.69 & 0.77 & 0.03 & 0.02 & 0.00 .0 & 0.0 & 0.0 \\
\hline$n$ & 00 & 02 & 00 & 00 & 01 & 00 & 01 & 3 & 0.005 & 1 & 0.049 & 0.001 & 0.00 & 0.000 & .000 & 6 & 1 & 8 & 7 & 0000 & 00 & 01 \\
\hline$X(p h$ & 0.0 & 0.1 & 0.1 & 0.1 & 0.1 & 0.2 & 0.2 & 0.39 & ר? & 0.47 & 0347 & 0340 & 042 & 4 & 420 & 0.23 & 0.33 & 0.01 & 0.00 & & & \\
\hline ase) & 98 & 02 & 29 & 52 & 76 & 03 & 07 & 9 & 0.272 & 6 & 0.347 & 0.040 & & .4 & $4<U$ & 6 & 2 & 2 & 0 & & - & \\
\hline$Y(p h$ & 0.1 & 0.1 & 0.1 & 0.1 & 0.1 & 0.1 & 0.2 & 0.10 & 0.027 & 1.42 & 1159 & 0.471 & 0495 & 0.527 & 0.476 & 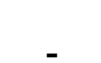 & - & - & & 0.00 .1 & & \\
\hline ase) & 96 & 74 & 56 & 53 & 54 & 77 & 19 & 0 & & 5 & & ו וד. & 0.75 & & & & & & & 8674 & & \\
\hline
\end{tabular}
NOTES: Microprobe data presented here are calculated from RAW data via AX_2 program (Holland; http://www.esc.cam.ac.uk/research/research-groups/holland/ax); X (grt) $=\mathrm{Xpy}=\mathrm{Mg}\left(\mathrm{Fe}^{2+}+\mathrm{Mn}+\mathrm{Mg}+\mathrm{Ca}\right), \mathrm{X}(\mathrm{omp})=\mathrm{Xjd}, \mathrm{X}(\mathrm{Brs}$, gln, chl $)=\mathrm{Fe}^{2+} /\left(\mathrm{F}^{\mathrm{e} 2+}+\mathrm{Mg}\right), \mathrm{X}(\mathrm{Ph}, \mathrm{pa})=\mathrm{Mg}^{2+} ; \mathrm{Y}(\mathrm{grt})=\mathrm{Xgr}=\mathrm{Ca} /(\mathrm{Fe} 2++\mathrm{Mn}+\mathrm{Mg}+\mathrm{Ca}), \mathrm{Y}(\mathrm{omp})=\mathrm{j}(\mathrm{o})=\mathrm{Na} /(\mathrm{Na}+\mathrm{Ca}), \mathrm{Y}$ $(\mathrm{gln}, \mathrm{ep}, \mathrm{czo})=\mathrm{Fe}^{3+} /\left(\mathrm{Fe}^{3+}+\mathrm{AlVI}\right), \mathrm{Y}(\mathrm{Brs})=(\mathrm{Na}) \mathrm{M} 4$; c, core; $\mathrm{m}$, mantle; $r$, rim; -in-phase: inclusion mineral in phase, -matrix: mineral in the matrix; "-" means did not calculate. 
Table 4

\begin{tabular}{|c|c|c|c|c|c|c|c|c|c|c|c|c|c|c|}
\hline \multirow[b]{3}{*}{$\begin{array}{c}\text { Eleme } \\
\mathrm{nt}\end{array}$} & & & \multirow{2}{*}{\multicolumn{2}{|c|}{$\begin{array}{l}\text { Garnet } \\
\text { Mantle }\end{array}$}} & \multirow{2}{*}{\multicolumn{2}{|c|}{ Rim }} & \multicolumn{6}{|c|}{ Zircon } & & \\
\hline & \multicolumn{2}{|c|}{ Core } & & & & & \multicolumn{2}{|c|}{ Core } & \multicolumn{2}{|c|}{$\begin{array}{c}\text { Core high } \\
\text { HREEs }\end{array}$} & \multicolumn{2}{|c|}{ Mantle } & \multicolumn{2}{|c|}{$\operatorname{Rim}$} \\
\hline & $\begin{array}{c}\text { Avera } \\
\text { ge }\end{array}$ & $\begin{array}{c}\text { Std }(N \\
=8)\end{array}$ & $\begin{array}{c}\text { Avera } \\
\text { ge }\end{array}$ & $\begin{array}{c}\text { Std }(N \\
=9)\end{array}$ & $\begin{array}{c}\text { Avera } \\
\text { ge }\end{array}$ & $\begin{array}{c}\mathrm{Std}(\mathrm{N}= \\
10)\end{array}$ & $\begin{array}{c}\text { Avera } \\
\text { ge }\end{array}$ & $\begin{array}{c}\mathrm{Std}(\mathrm{N}= \\
30)\end{array}$ & $\begin{array}{c}\text { Avera } \\
\text { ge }\end{array}$ & $\begin{array}{c}\text { Std(N } \\
=5)\end{array}$ & $\begin{array}{c}\text { Avera } \\
\text { ge }\end{array}$ & $\begin{array}{c}\text { Std }(N \\
=4)\end{array}$ & $\begin{array}{c}\text { Avera } \\
\text { ge }\end{array}$ & $\begin{array}{c}\operatorname{Std}(N= \\
15)\end{array}$ \\
\hline$P$ & 53.5 & 31.9 & 117 & 155 & 13.9 & 2.84 & 27.2 & 9.92 & 34.6 & 10.4 & - & - & 21.2 & 6.27 \\
\hline $\mathrm{Ti}$ & 681 & 152 & 1661 & 979 & 106 & 17.5 & 2.89 & 1.04 & 10.6 & 3.77 & 1.55 & 0.140 & 1.93 & 0.930 \\
\hline $\mathrm{La}$ & bd & bd & 0.471 & 0.356 & bd & bd & bd & bd & bd & bd & bd & bd & bd & bd \\
\hline $\mathrm{Ce}$ & 0.181 & 0.204 & 1.63 & 1.35 & bd & $\mathrm{bd}$ & 0.121 & 0.060 & 0.123 & 0.064 & bd & bd & bd & bd \\
\hline $\mathrm{Pr}$ & 0.042 & 0.015 & 0.314 & 0.214 & $\mathrm{bd}$ & $\mathrm{bd}$ & $\mathrm{bd}$ & $\mathrm{bd}$ & bd & $\mathrm{bd}$ & bd & $\mathrm{bd}$ & bd & bd \\
\hline $\mathrm{Nd}$ & 0.308 & 0.249 & 2.38 & 1.16 & $\mathrm{bd}$ & $b d$ & $\mathrm{bd}$ & bd & bd & $\mathrm{bd}$ & bd & $\mathrm{bd}$ & bd & bd \\
\hline $\mathrm{Sm}$ & 0.746 & 0.245 & 1.77 & 0.590 & $\mathrm{bd}$ & $\mathrm{bd}$ & 0.336 & 0.051 & 0.420 & 0.269 & $\mathrm{bd}$ & $\mathrm{bd}$ & $\mathrm{bd}$ & $\mathrm{bd}$ \\
\hline Dy & 13.9 & 2.74 & 8.91 & 1.95 & 8.46 & 0.772 & 10.5 & 2.14 & 24.0 & 6.72 & 4.91 & 1.80 & 2.03 & 1.32 \\
\hline $\mathrm{Ho}$ & 3.38 & 0.788 & 1.89 & 0.458 & 1.89 & 0.208 & 2.40 & 0.539 & 6.70 & 1.86 & 1.01 & 0.411 & 0.913 & 0.603 \\
\hline $\mathrm{Er}$ & 10.0 & 2.64 & 5.23 & 1.37 & 4.87 & 0.614 & 6.63 & 1.62 & 20.37 & 5.64 & 2.69 & 0.853 & 5.48 & 3.38 \\
\hline $\mathrm{Tm}$ & 1.56 & 0.455 & 0.703 & 0.193 & 0.646 & 0.096 & 1.03 & 0.271 & 3.18 & 0.791 & 0.351 & 0.096 & 1.65 & 0.994 \\
\hline $\mathrm{Yb}$ & 11.2 & 3.58 & 4.72 & 1.29 & 4.19 & 0.660 & 8.00 & 2.00 & 23.72 & 5.80 & 3.00 & 1.13 & 20.2 & 10.9 \\
\hline $\mathrm{Lu}$ & 1.54 & 0.535 & 0.654 & 0.187 & 0.654 & 0.098 & 1.28 & 0.331 & 3.61 & 1.01 & 0.450 & 0.190 & 4.42 & 2.47 \\
\hline
\end{tabular}




\begin{tabular}{|c|c|c|c|c|c|c|c|c|c|c|c|c|c|c|}
\hline $\mathrm{Ta}$ & $\mathrm{bd}$ & $\mathrm{bd}$ & $b d$ & $\mathrm{bd}$ & $b d$ & bd & 0.071 & 0.044 & 0.077 & 0.026 & 0.095 & 0.042 & 0.099 & 0.054 \\
\hline $\mathrm{Hf}$ & $\mathrm{bd}$ & $\mathrm{bd}$ & $\mathrm{bd}$ & $\mathrm{bd}$ & $\mathrm{bd}$ & bd & 10127 & 366 & 10306 & 359 & 10553 & 317 & 10341 & 671 \\
\hline Th & bd & $\mathrm{bd}$ & bd & $\mathrm{bd}$ & bd & $\mathrm{bd}$ & 3.59 & 3.00 & 5.39 & 5.27 & 2.86 & 1.57 & 0.174 & 0.107 \\
\hline U & bd & $\mathrm{bd}$ & bd & $\mathrm{bd}$ & bd & $\mathrm{bd}$ & 982 & 660 & 982 & 657 & 740 & 255 & 30.6 & 34.9 \\
\hline $\begin{array}{c}(\mathrm{Lu} / \mathrm{S} \\
\mathrm{m})_{\mathrm{N}}\end{array}$ & 12.4 & & 2.23 & & - & & 22.9 & & 51.7 & & - & & - & \\
\hline $\begin{array}{c}(\mathrm{Lu} / \mathrm{Tb} \\
)_{\mathrm{N}} \\
\end{array}$ & 1.35 & & 0.779 & & 1.04 & & 1.53 & & 2.71 & & 0.940 & & 33.9 & \\
\hline
\end{tabular}

NOTES: "bd" means below detected; "-" do not calculated; Here the Std-dev is 1 sigma; 
Table 5

\begin{tabular}{|c|c|c|c|c|c|c|c|c|c|c|c|}
\hline Zircon core $(n=31)$ & $\begin{array}{c}\mathrm{U} \\
(\mathrm{ug} / \mathrm{g})(\end{array}$ & $\begin{array}{l}\text { Th } \\
(\mathrm{ug} / \mathrm{g})\end{array}$ & ${ }^{207} \underline{\mathrm{Pb}}$ & $\begin{array}{c} \pm 1 s \\
\%\end{array}$ & ${ }^{206} \mathrm{~Pb}$ & $\begin{array}{c} \pm 1 s \\
\%\end{array}$ & $\rho$ & ${ }^{207} \underline{\mathrm{Pb}}$ & $\pm 1 \mathrm{~s}$ & ${ }^{206} \underline{\mathrm{Pb}}$ & $\pm 1 \mathrm{~s}$ \\
\hline 11AT06-1a@10 & 631 & 1.690 .003 & 0.330 .36991 & 2.56 & 0.0505 & 1.50 & 0.5882 & 319.6 & 7.0 & 317.4 & 4.7 \\
\hline 11AT06-1a@14 & 659 & 2.440 .004 & 0.130 .36494 & 2.68 & 0.0495 & 1.50 & 0.5614 & 315.9 & 7.3 & 311.2 & 4.6 \\
\hline 11AT06-1a@15 & 750 & 2.940 .004 & 0.230 .36427 & 2.73 & 0.0496 & 1.50 & 0.5500 & 315.4 & 7.4 & 311.8 & 4.6 \\
\hline 11AT06-1a@18 & 612 & 1.290 .002 & 0.430 .36714 & 2.53 & 0.0500 & 1.50 & 0.5956 & 317.5 & 6.9 & 314.7 & 4.6 \\
\hline 11AT06-1a@2 & 746 & 1.940 .003 & 0.030 .36225 & 2.07 & 0.0507 & 1.50 & 0.7258 & 313.9 & 5.6 & 318.7 & 4.7 \\
\hline 11AT06-1a@20 & 795 & 2.690 .003 & 0.230 .35596 & 2.91 & 0.0493 & 1.51 & 0.5199 & 309.2 & 7.8 & 310.0 & 4.6 \\
\hline 11AT06-1a@28 & 653 & 1.570 .002 & 0.090 .37086 & 2.39 & 0.0509 & 1.54 & 0.6442 & 320.3 & 6.6 & 320.1 & 4.8 \\
\hline 11AT06-1a@29 & 1114 & 4.020 .004 & 0.110 .37306 & 1.96 & 0.0506 & 1.50 & 0.7682 & 321.9 & 5.4 & 318.2 & 4.7 \\
\hline 11AT06-1a@32 & 671 & 1.160 .002 & 0.290 .35594 & 2.25 & 0.0499 & 1.50 & 0.6686 & 309.2 & 6.0 & 313.9 & 4.6 \\
\hline 11AT06-1a@36 & 870 & 4.550 .005 & 0.220 .37544 & 2.29 & 0.0505 & 1.50 & 0.6566 & 323.7 & 6.4 & 317.8 & 4.7 \\
\hline 11AT06-1a@38 & 1034 & 3.460 .003 & 0.210 .36159 & 2.69 & 0.0493 & 1.51 & 0.5630 & 313.4 & 7.3 & 310.4 & 4.6 \\
\hline 11AT06-1a@39 & 624 & 2.030 .003 & 0.110 .37371 & 2.64 & 0.0497 & 1.51 & 0.5699 & 322.4 & 7.3 & 313.0 & 4.6 \\
\hline 11AT06-1a@6 & 731 & 3.470 .005 & 0.190 .37025 & 2.14 & 0.0509 & 1.51 & 0.7046 & 319.8 & 5.9 & 320.1 & 4.7 \\
\hline 11AT06-1b@6 & 992 & 3.080 .003 & 0.090 .36843 & 1.82 & 0.0506 & 1.50 & 0.8259 & 318.5 & 5.0 & 318.4 & 4.7 \\
\hline 11AT06-1c @2 & 642 & 2.000 .003 & 0.000 .35589 & 1.82 & 0.0496 & 1.55 & 0.8485 & 309.1 & 4.9 & 312.1 & 4.7 \\
\hline 11AT06-1c @6 & 1021 & 3.930 .004 & 0.480 .37138 & 2.05 & 0.0506 & 1.67 & 0.8115 & 320.7 & 5.7 & 318.2 & 5.2 \\
\hline 11AT06-1d@1 & 582 & 1.770 .003 & 0.000 .36228 & 1.86 & 0.0496 & 1.53 & 0.8221 & 313.9 & 5.0 & 312.0 & 4.7 \\
\hline 11AT06-1d@33 & 180 & 0.450 .003 & 0.820 .36347 & 3.96 & 0.0499 & 1.51 & 0.3817 & 314.8 & 10.8 & 314.0 & 4.6 \\
\hline 11AT06-1d @22 & 571 & 1.290 .002 & 0.040 .37170 & 1.86 & 0.0499 & 1.50 & 0.8071 & 320.9 & 5.1 & 314.1 & 4.6 \\
\hline 11AT06-1d@6 & 1140 & 4.000 .004 & 0.000 .36469 & 1.72 & 0.0500 & 1.56 & 0.9084 & 315.7 & 4.7 & 314.4 & 4.8 \\
\hline 11AT06-1d@19 & 439 & 0.650 .001 & 0.060 .36804 & 2.00 & 0.0506 & 1.50 & 0.7510 & 318.2 & 5.5 & 318.1 & 4.7 \\
\hline
\end{tabular}


11AT06-1d@30

11AT06-1d@7

11AT06-1a@23

11AT06-1d@10

11AT06-1a@35

11AT06-1b@34

11AT06-1d@13

11AT06-1a@33

11AT06-1d@14

11AT06-1e@2

Zircon core with high HREEs $(n=4)$

11AT06-1b @1

11AT06-1d@29

11AT06-1a@42

11AT06-1b@5

Zircon mantle $(\mathrm{n}=7)$

11AT06-1a@1

11AT06-1a@11

11AT06-1a@21

11AT06-1a@9

11AT06-1a@37

11AT06-1c@1

11AT06-1d@8 $\begin{array}{lllll}751 & 3.540 .005 & 0.020 .37868 & 2.13 & 0.0510\end{array}$ $\begin{array}{llllll}460 & 1.190 .003 & 0.200 .37550 & 2.12 & 0.0516\end{array}$ $\begin{array}{llllll}1347 & 3.370 .002 & 0.030 .37595 & 1.85 & 0.0514\end{array}$ $\begin{array}{llllll}2250 & 6.570 .003 & 0.010 .37210 & 1.60 & 0.0505\end{array}$ $\begin{array}{llllll}1051 & 4.760 .005 & 0.040 .37629 & 2.00 & 0.0505\end{array}$ $\begin{array}{lllll}335425.690 .008 & 0.150 .37570 & 1.59 & 0.0509\end{array}$ $\begin{array}{llllll}2740 & 11.910 .004 & 0.240 .37897 & 1.92 & 0.0515\end{array}$ $\begin{array}{llllll}628 & 1.390 .002 & 0.100 .36444 & 2.48 & 0.0501\end{array}$ $\begin{array}{llllll}573 & 1.720 .003 & 0.000 .37136 & 1.97 & 0.0503\end{array}$ $\begin{array}{llllll}1153 & 4.640 .004 & 1.600 .37476 & 3.16 & 0.0496\end{array}$

$\begin{array}{lllll}991 & 2.230 .002 & 0.060 .36720 & 1.71 & 0.0502\end{array}$ $\begin{array}{llllll}476 & 1.010 .002 & 0.020 .38270 & 1.96 & 0.0506\end{array}$ $\begin{array}{lllll}3392 & 14.140 .004 & 0.030 .37221 & 1.79 & 0.0510\end{array}$ $\begin{array}{llllll}605 & 1.620 .003 & 0.180 .36372 & 1.79 & 0.0501\end{array}$

$9714.000 .004\{0.28\} 0.35010 \quad 2.32 \quad 0.0480$ $\begin{array}{lllll}999 & 4.000 .004\{0.30\} 0.34716 & 2.98 & 0.0477\end{array}$ $\begin{array}{lllll}700 & 2.000 .003\{0.13\} 0.35383 & 2.70 & 0.0482\end{array}$

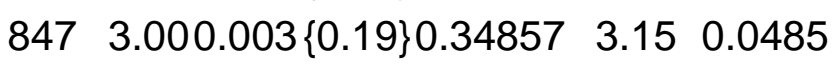
$\begin{array}{lllll}661 & 3.000 .004\{0.50\} & 0.35923 & 3.12 & 0.0488\end{array}$ $\begin{array}{lllll}31 & 0.060 .002\{0.00\} & 0.35326 & 6.18 & 0.0472\end{array}$ $2160.580 .003\{1.43\} 0.3163310 .200 .0486$

\begin{tabular}{rrrrrr}
1.52 & 0.7131 & 326.1 & 6.0 & 320.6 & 4.8 \\
1.50 & 0.7079 & 323.7 & 5.9 & 324.3 & 4.8 \\
1.50 & 0.8098 & 324.1 & 5.2 & 323.4 & 4.7 \\
1.52 & 0.9451 & 321.2 & 4.4 & 317.8 & 4.7 \\
1.50 & 0.7528 & 324.3 & 5.6 & 317.5 & 4.7 \\
1.51 & 0.9441 & 323.9 & 4.4 & 320.2 & 4.7 \\
1.53 & 0.8000 & 326.3 & 5.4 & 323.8 & 4.8 \\
1.53 & 0.6188 & 315.5 & 6.7 & 315.0 & 4.7 \\
1.51 & 0.7661 & 320.7 & 5.4 & 316.4 & 4.7 \\
1.51 & 0.4790 & 323.2 & 8.8 & 312.1 & 4.6 \\
& & & & & \\
1.50 & 0.8780 & 317.6 & 4.7 & 315.9 & 4.6 \\
1.50 & 0.7666 & 329.0 & 5.5 & 318.1 & 4.7 \\
1.50 & 0.8395 & 321.3 & 4.9 & 320.4 & 4.7 \\
1.51 & 0.8451 & 315.0 & 4.9 & 315.3 & 4.7 \\
& & & & & \\
1.52 & 0.6532 & 304.8 & 6.1 & 302.4 & 4.5 \\
1.54 & 0.5181 & 302.6 & 7.8 & 300.2 & 4.5 \\
1.52 & 0.5613 & 307.6 & 7.2 & 303.4 & 4.5 \\
1.52 & 0.4813 & 303.6 & 8.3 & 305.4 & 4.5 \\
1.50 & 0.4823 & 311.6 & 8.4 & 307.1 & 4.5 \\
1.56 & 0.2519 & 307.2 & 16.5 & 297.2 & 4.5 \\
1.51 & 0.1480 & 279.1 & 25.2 & 305.6 & 4.5 \\
\hline
\end{tabular}


continued

\begin{tabular}{|c|c|c|c|c|c|c|c|c|c|c|}
\hline Zircon rim $(n=8)$ & $\begin{array}{c}U \\
(\mathrm{ug} / \mathrm{g})\end{array}$ & $\begin{array}{c}\text { Th } \\
(\mathrm{ug} / \mathrm{g})\end{array}$ & $\mathrm{Th} / \mathrm{U}$ & $\begin{array}{l}f_{206} \\
(\%)\end{array}$ & 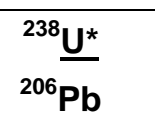 & $\begin{array}{c} \pm 1 s \\
\%\end{array}$ & ${ }^{206}{ }^{207} \mathrm{~Pb}^{*}$ & $\begin{array}{c} \pm 1 s \\
\%\end{array}$ & ${ }^{206} \mathrm{~Pb}$ & $\pm 1 \mathrm{~s}$ \\
\hline 11AT06-1a@13 & 665 & 1.64 & 0.002 & $\{1.32\}$ & 22.149 & 1.58 & 0.05735 & 1.90 & 281.0 & 4.4 \\
\hline 11AT06-1a@31 & 287 & 1.66 & 0.006 & $\{0.09\}$ & 22.896 & 1.51 & 0.05207 & 2.69 & 275.6 & 4.1 \\
\hline 11AT06-1a@7 & 187 & 0.66 & 0.004 & $\{0.00\}$ & 22.241 & 1.57 & 0.05238 & 4.20 & 283.5 & 4.3 \\
\hline 11AT06-1d@31 & 8 & 0.03 & 0.004 & $\{9.84\}$ & 19.487 & 9.29 & 0.14442 & 9.81 & 291.6 & 11.1 \\
\hline 11AT06-1e @3 & 5 & 0.02 & 0.004\{ & $\{10.30\}$ & 19.625 & 9.667 & 0.10951 & 15.34 & 288.1 & 10.5 \\
\hline 11AT06-1e@4 & 1 & 0.01 & 0.009 & $\{14.43\}$ & 19.6561 & 10.210 & 0.08647 & 20.06 & 274.7 & 20.7 \\
\hline 11AT06-1d@9 & 49 & 0.15 & 0.003\{ & $\{34.21\}$ & 15.081 & 3.06 & 0.29376 & 3.04 & 275.3 & 7.9 \\
\hline 11AT06-1d @34 & 6 & 0.05 & 0.009 & $\{24.88\}$ & 16.306 & 5.14 & 0.20910 & 6.17 & 290.3 & 13.7 \\
\hline
\end{tabular}

NOTES: $f^{206}(\%)$ is the percentage of common ${ }^{206} \mathrm{~Pb}$ in total ${ }^{206} \mathrm{~Pb}$, calculated by ${ }^{207} \mathrm{~Pb}$-based; $\mathrm{t}_{206 / 238}$ is

${ }^{206} \mathrm{~Pb}-{ }^{238} \mathrm{U}$ age calculated by ${ }^{207} \mathrm{~Pb}$-based common-lead correction; "*" means that the ratios are common

$\mathrm{Pb}$ uncorrected; 
Table 6

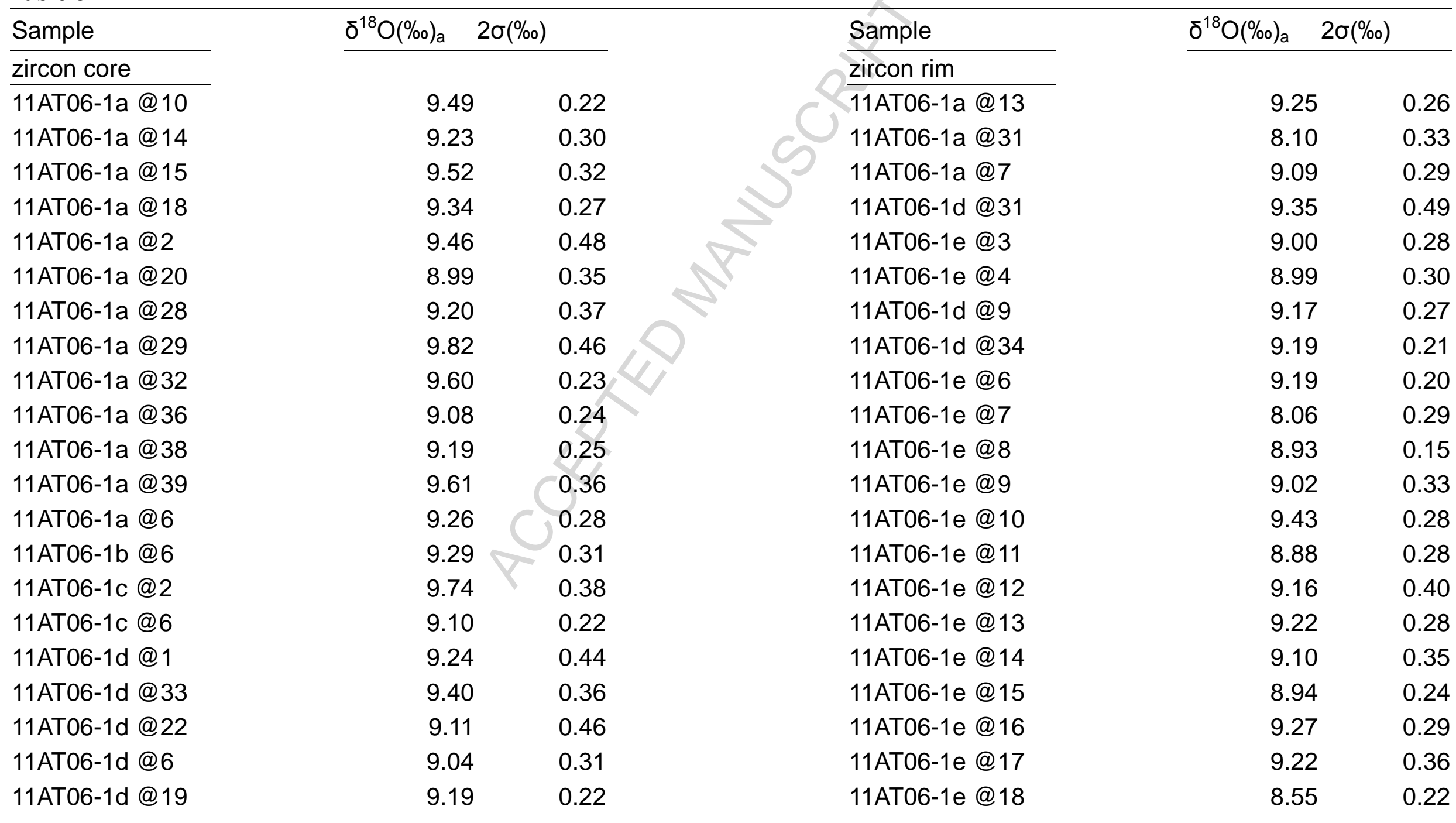




\begin{tabular}{|c|c|c|c|c|c|}
\hline 11AT06-1d @30 & 8.90 & 0.23 & 11AT06-1e @19 & 8.91 & 0.44 \\
\hline & & & 11AT06-1e @20 & 8.66 & 0.22 \\
\hline zircon mantle & & & & & \\
\hline 11AT06-1a@1 & 9.71 & 0.25 & zircon high HREEs & & \\
\hline 11AT06-1a@11 & 9.44 & 0.37 & 11AT06-1b@1 & 9.49 & 0.22 \\
\hline 11AT06-1a @21 & 8.87 & 0.20 & 11AT06-1a@42 & 9.45 & 0.46 \\
\hline 11AT06-1a @9 & 8.35 & 0.39 & 11AT06-1b@7 & 8.98 & 0.47 \\
\hline Modeled results & $\delta^{18} \mathrm{O}(\%)$ & Assumed mode in $\mathrm{P}$ peak (vol \%) & assumed end-member & & \\
\hline zircon & 9.0000 & 1.00 & zircon $100 \%$ & & \\
\hline garnet & 9.0995 & 20.00 & alm60\%,grs20\%,prp20\% & & \\
\hline omphacite & 9.1144 & 70.00 & Di50\%,Jd50\% & & \\
\hline
\end{tabular}

NOTES: ${ }^{a}$ The $\delta^{18} \mathrm{O}$ values have been corrected by the instrumental mass fractionation; Modeled results were calculated based on methods and relevant factors from Zheng (1991, 1993); P peak is setted on $530^{\circ} \mathrm{C}$. 
Table 7

\begin{tabular}{|c|c|c|c|c|c|c|c|c|c|}
\hline \multirow{2}{*}{$\frac{\text { Sample }}{11 \text { AT06-2 }}$} & \multicolumn{2}{|c|}{ Mineral Sm (ppm } & $\mathrm{Nd}(\mathrm{ppm})$ & \multicolumn{5}{|c|}{${ }^{7} \mathrm{Sm} /{ }^{144} \mathrm{Nd}{ }^{143} \mathrm{Nd} /{ }^{144} \mathrm{Nd}{ }^{143} \mathrm{Nd} /{ }^{144} \mathrm{Nd}$ errorgrt-omp-WR age (Ma) grt-omp age (Ma) } & \multirow{2}{*}{$\frac{\varepsilon_{\mathrm{Nd}}(\mathrm{t})}{8.5}$} \\
\hline & WR & 1.680 & 4.260 & 0.2841 & 0.513251 & 0.000008 & $312.1 \pm 2.4$ & $311.9 \pm 2.6$ & \\
\hline & grt1 & 0.621 & 0.292 & 1.2843 & 0.515307 & 0.000014 & & & \\
\hline & grt2 & 0.624 & 0.294 & 1.2828 & 0.515286 & 0.000018 & & & \\
\hline & omp1 & 0.287 & 0.692 & 0.2510 & 0.513186 & 0.000011 & & & \\
\hline & omp2 & 0.290 & 0.714 & 0.2452 & 0.513180 & 0.000022 & & & \\
\hline
\end{tabular}

NOTES: WR means the whole rock, the absolute errors of ${ }^{143} \mathrm{Nd} /{ }^{144} \mathrm{Nd}$ and isochron ages are given in $2 \sigma ; \lambda=6.54 \times 10-12$ year-1; ${ }^{147} \mathrm{Sm} /{ }^{144} \mathrm{NdCHUR}=0.1967,{ }^{147} \mathrm{Sm} /{ }^{144} \mathrm{NdDM}=0.2137,{ }^{143} \mathrm{Nd} /{ }^{144} \mathrm{NdCHUR}(0)=0.512638,{ }^{143} \mathrm{Nd} /{ }^{144} \mathrm{NdDM}(0)=0.513151$ are used for the calculation. 


\section{Highlights}

- Constant $\delta^{18} \mathrm{O}$ of multistage zircon domains suggest a nearly closed metamorphic system.

- Multistage zircon ages are tied to metamorphism by test REE partitioning with garnet.

- Detailed P-T-t-isotopic history of SW-Tianshan coesite-bearing eclogite is obtained.

- Zircon chronology and Sm-Nd isochron constrain peak burial at ca. $315 \pm 5 \mathrm{Ma}$.

- Exhaustively compiled regional data outline a short-lived detachment and exhumation. 